\title{
Enantioselective Total Syntheses of Kuwanon X, Kuwanon Y, and Kuwanol A
}

Lei Gao, ${ }^{\dagger+}$ Jianguang Han, ${ }^{*}$ and Xiaoguang Lei ${ }^{*} \dagger,+, \$$

Graduate School of Peking Union Medical College and Chinese Academy of Medical Sciences, Beijing 100730, China

${ }^{*}$ National Institute of Biological Sciences (NIBS), Beijing 102206, China

$\S_{B}$ Beijing National Laboratory for Molecular Sciences, Department of Chemical Biology, College of Chemistry and Molecular Engineering, Synthetic and Functional Biomolecules Center, and Peking-Tsinghua Center for Life Sciences, Peking University, Beijing 100871, China

xglei@pku.edu.cn

\section{Supporting Information}

\begin{tabular}{|l|l|}
\hline $\begin{array}{l}\text { I) Proposed Mechanism for the Exo-selective Asymmetric } \\
\text { Diels-Alder Cycloaddition. }\end{array}$ & $\mathrm{S} 2$ \\
\hline II) Proposed Explanation for the Endo-selective Acid-induced & $\mathrm{S} 2$ \\
Ketalization & \\
\hline III) Experimental Section. & \\
\hline a) General information & $\mathrm{S} 3$ \\
\hline b) Detailed experimental procedures & $\mathrm{S} 4-\mathrm{S} 25$ \\
\hline IV) Comparison of Natural and Synthetic Kuwanons X and Y, & $\mathrm{S} 26-\mathrm{S} 28$ \\
\hline Kuwanol A & \\
\hline V) ${ }^{\mathbf{1} H \text { and }}{ }^{13}$ C NMR Spectra & $\mathrm{S} 29-\mathrm{S} 45$ \\
\hline
\end{tabular}




\section{I) The Proposed Mechanism for the Exo-selective Asymmetric Diels-}

\section{Alder Cycloaddition.}

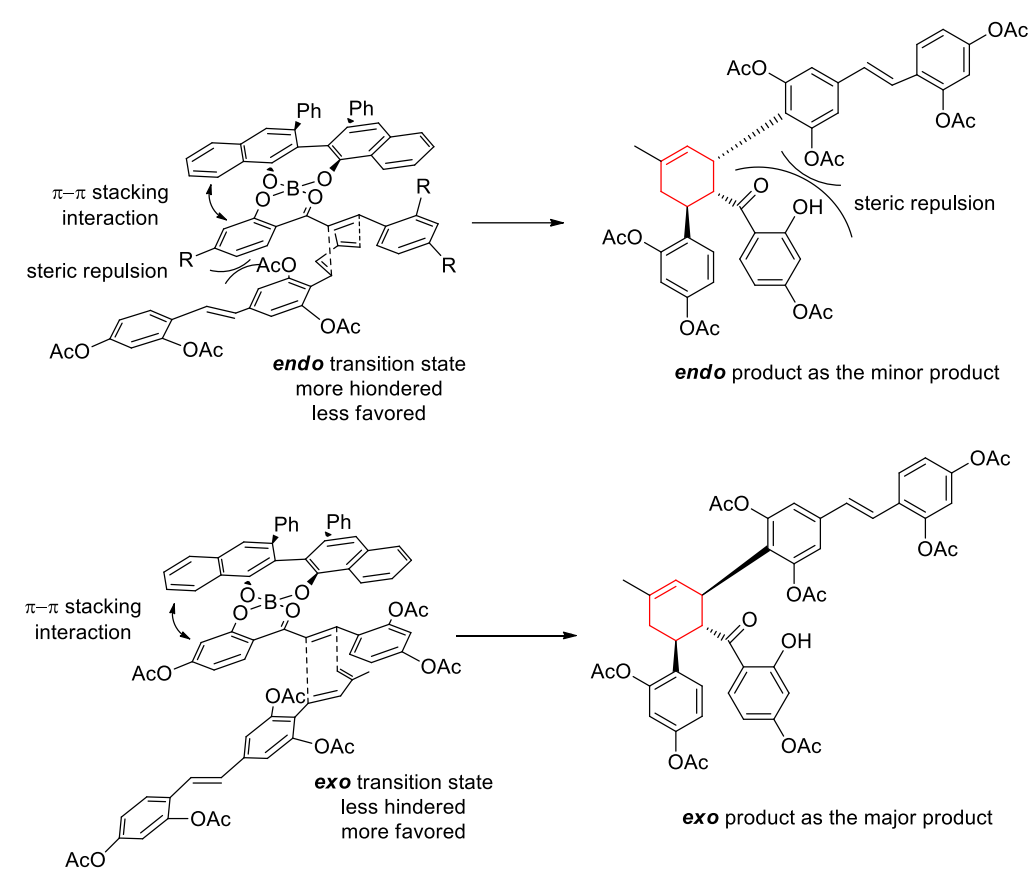

This Diels-Alder reaction features high enantioselectivity and exo selectivity which can be explained by the two transition states. The chiral ligand blocks the $\alpha$-face of the dienophile in both endo and exo transition states, so the diene could only approach the dienophile by its less hindered $\beta$-face. Because of the steric hindrance between the acetyl group and the phenyl group, the less hindered exo transition state is more favored to show exo selectivity in this asymmetric Diel-Alder cycloaddition.

\section{II) Proposed Explanation for the Endo-selective Acid-induced}

\section{ketalization.}

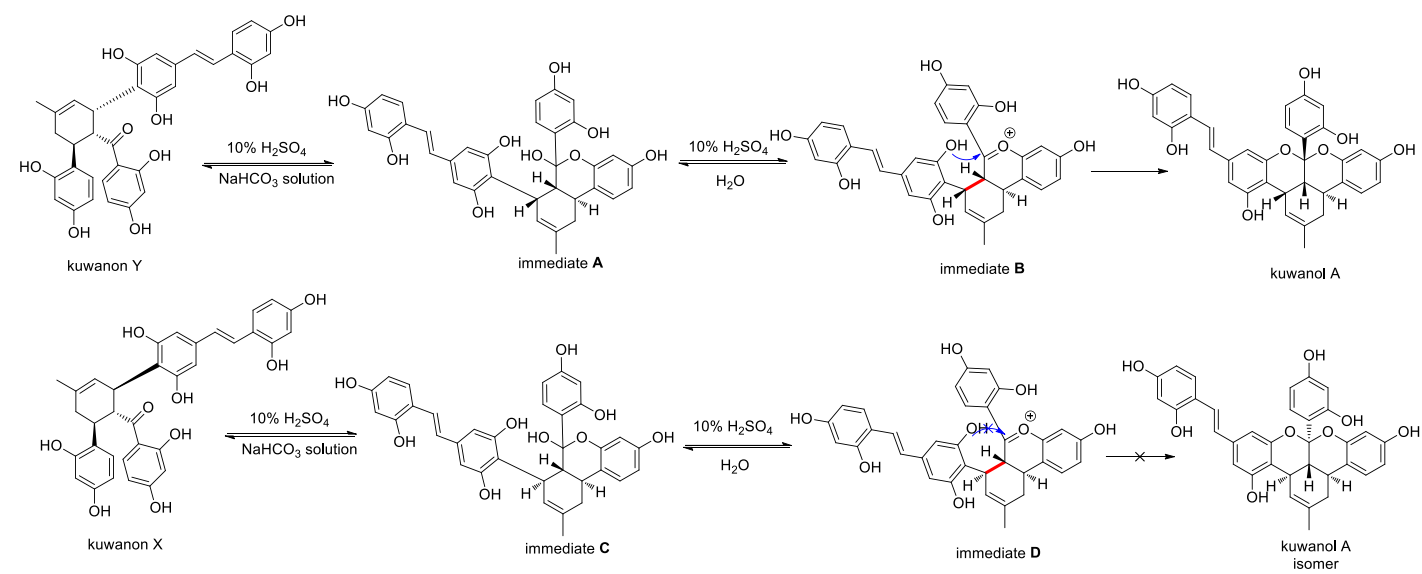

When kuwanon $\mathrm{X}$ was used as the substrate to do the acid-induced ketalization reaction, we could detect the existence of immediate $\mathrm{C}$. But this immediate $\mathrm{C}$ was very unstable. After quenching the reaction by saturated $\mathrm{NaHCO}_{3}$ aqueous solution, this immediate $\mathrm{C}$ disappeared and only the kuwanon $\mathrm{X}$ was recovered. Based on this results, we proposed the mechanism for the ketalization of kuwanons $\mathrm{X}$ and $\mathrm{Y}$. 
In immediate $\mathrm{B}$, the phenolic hydroxyl group and the oxonium ion are oriented in the same direction, so the oxonium ion will be accessible to the hydroxyl group and then ketalized natural product can be obtained. As to immediate $\mathrm{D}$, the oxonium ion is too far for the hydroxyl group to attack, so the new six-member ring can't be formed.

\section{III) Experimental Section}

\section{a) General information:}

${ }^{1} \mathrm{H}$ NMR spectra were recorded on a Varian $400 \mathrm{MHz}$ spectrometer at ambient temperature with $\mathrm{CDCl}_{3}$ as the solvent unless otherwise stated. ${ }^{13} \mathrm{C}$ NMR spectra were recorded on a Varian $100 \mathrm{MHz}$ spectrometer (with complete proton decoupling) at ambient temperature; The NMR spectra of Kuwanon $\mathrm{X}$ were recorded on a Bruker spectrometer $\left({ }^{1} \mathrm{H}\right.$ at $500 \mathrm{MHz}$ and ${ }^{13} \mathrm{C}$ at $\left.125 \mathrm{MHz}\right)$. Chemical shifts are reported in parts per million relative to chloroform $\left({ }^{1} \mathrm{H}, \delta 7.26 ;{ }^{13} \mathrm{C}, \delta 77.10\right)$, acetone- $d_{6}\left({ }^{1} \mathrm{H}, \delta 2.05 ;{ }^{13} \mathrm{C}\right.$, $\delta$ 29.8), DMSO- $d_{6}\left({ }^{1} \mathrm{H}, \delta 2.5 ;{ }^{13} \mathrm{C}, \delta 39.5\right)$. Data for ${ }^{1} \mathrm{H}$ NMR are reported as follows: chemical shift, integration, multiplicity ( $\mathrm{s}=$ singlet, $\mathrm{d}=$ doublet, $\mathrm{t}=$ triplet, $\mathrm{m}=$ multiplet, $\mathrm{br}=$ broad $)$ and coupling constants (Hz). Infrared spectra were recorded on a Thermo Fisher FT-IR200 spectrophotometer. High-resolution mass spectra were obtained at Peking University Mass Spectrometry Laboratory using a Bruker APEX IV FTMS Flash chromatography. Optical rotations were recorded on an AUTOPOL III digital polarimeter at $589 \mathrm{~nm}$ and are recorded as $[\alpha]_{\mathrm{D}}^{25}$ (concentration in grams/100 mL solvent). The samples were analyzed by HPLC/MS on a Waters Auto Purification LC/MS system (3100 Mass Detector, 2545 Binary Gradient Module, 2767 Sample Manager, and 2998 Photodiode Array (PDA)

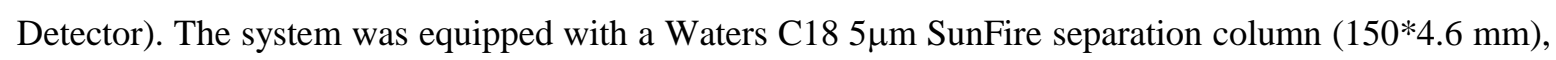
equilibrated with HPLC grade water (solvent A) and HPLC grade methanol (solvent B) with a flow rate of $1.0 \mathrm{~mL} / \mathrm{min}$ at rt. Chiral HPLC analysis was performed on an Agilent 1200 series (CHIRALCEL AD-H, Column No. ADH0CE-MK114). Analytical thin layer chromatography was performed using $0.25 \mathrm{~mm}$ silica gel 60-F plates. Flash chromatography was performed using 200-400 mesh silica gel. Yields refer to chromatographically and spectroscopically pure materials, unless otherwise stated. All reagents were used as supplied by Sigma-Aldrich, J\&K and Alfa Aesar Chemicals. Methylene chloride, Methanol and N,N-dimethylformamide were distilled from calcium hydride; tetrahydrofuran was distilled from sodium/benzophenone ketyl prior to use. All reactions were carried out in oven-dried glassware under an argon atmosphere unless otherwise noted. 


\section{b) Detailed experimental procedures}<smiles>COC(=O)c1cc(O)cc(O)c1</smiles>

11<smiles>COC(=O)c1cc(O)c(I)c(O)c1</smiles>

12

\section{Methyl 3, 5-dihydroxy-4-iodobenzoate (12) ${ }^{1}$}

To a solution of $11(1.50 \mathrm{~g}, 8.92 \mathrm{mmol})$ in $\mathrm{MeOH}(10 \mathrm{~mL})$, a solution of NIS $(2.11 \mathrm{~g}, 9.37 \mathrm{mmol})$ in $\mathrm{MeOH}(10 \mathrm{~mL})$ was added slowly at $0{ }^{\circ} \mathrm{C}$. The reaction mixture was slowly warmed to room temperature while mixing. After $16 \mathrm{~h}$ the reaction mixture was diluted with ice water and quenched by saturated $\mathrm{Na}_{2} \mathrm{SO}_{3}$, then extracted with EtOAc. The combined organic layers were washed with brine, dried over $\mathrm{Na}_{2} \mathrm{SO}_{4}$ and concentrated in vacuo. After purification by flash column chromatography $\left(\mathrm{CH}_{2} \mathrm{Cl}_{2} / \mathrm{EtOAc}=5: 1\right)$, the title compound 12 was obtained as white solid in a yield of $2.54 \mathrm{~g}(8.64$ mmol, 97\%) with the same spectroscopic data as those previously reported.<smiles>COC(=O)c1cc(O)c(I)c(O)c1</smiles>

12<smiles>CCCCCOc1cc(C(=O)OC)cc(OCCCC)c1I</smiles>

13

\section{Methyl 3, 5-bis((tert-butyldimethylsilyl)oxy)-4-iodobenzoate (13)}

To a solution of $\mathbf{1 2}(2.00 \mathrm{~g}, 6.80 \mathrm{mmol})$ in $\mathrm{CH}_{2} \mathrm{Cl}_{2}(40 \mathrm{~mL})$, imidazole $(2.78 \mathrm{~g}, 40.8 \mathrm{mmol})$ and TBSCl ( $3.08 \mathrm{~g}, 20.4 \mathrm{mmol}$ ) was added sequentially at room temperature. After mixing for $2 \mathrm{~h}$, full conversion was obtained, as observed by TLC. The reaction mixture was quenched by water, extracted with $\mathrm{CH}_{2} \mathrm{Cl}_{2}$ and washed by brine. The organic layers were dried over $\mathrm{Na}_{2} \mathrm{SO}_{4}$ and concentrated in vacuo. After purification by flash column chromatography (petroleum ether/EtOAc $=10: 1$ ), the title compound $\mathbf{1 3}$ was obtained as white solid in a yield of $3.47 \mathrm{~g}(6.64 \mathrm{mmol}, 98 \%)$. Mp: $94-96{ }^{\circ} \mathrm{C} ;{ }^{1} \mathrm{H} \mathrm{NMR}(400 \mathrm{MHz}$, $\left.\mathrm{CDCl}_{3}\right) \delta 7.09$ (s, 2H), 3.89 (s, 3H), 1.07 (s, 18H), 0.304(s, 12H); $\left.{ }^{13} \mathrm{C} \mathrm{NMR} \mathrm{(100} \mathrm{MHz,} \mathrm{CDCl}_{3}\right) \delta 166.5$, 156.8, 131.0, 111.8, 94.4, 52.3, 25.9, 18.4, -4.0; IR (neat): $v_{\max }\left(\mathrm{cm}^{-1}\right)=2929,2857,1722,1571,1417$, 1250, 1095, 835, 782; HRMS (ESI) [M+H] ${ }^{+}$calculated for $\mathrm{C}_{20} \mathrm{H}_{35} \mathrm{IO}_{4} \mathrm{Si}_{2}: 523.1191$, found: 523.1200.

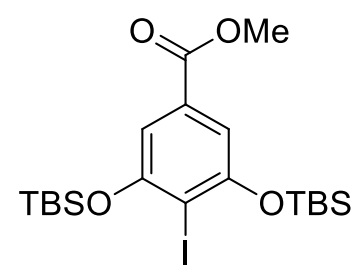

13<smiles>CC(C)(C)Oc1cc(CO)cc(O[SbH3])c1I</smiles>

14

\section{(3, 5-Bis((tert-butyldimethylsilyl)oxy)-4-iodophenyl)methanol (14)}

1 (a) Berliner, M. A.; Cordi, E. M.; Dunetz, J. R.; Price, K. E. Org. Process Res. Dev. 2010, 14, 180. (b) Chiummiento, L.; Funicello, M.; Lopardo, M. T.; Lupattelli, P.; Choppin, S.; Colobert, F. Eur. J. Org. Chem. 2012, 188. 
To a solution of $13(2.00 \mathrm{~g}, 3.83 \mathrm{mmol})$ in THF $(15 \mathrm{~mL})$, DIBAL $(8.42 \mathrm{~mL}, 1 \mathrm{M}$ in THF) was added slowly at ${ }^{\circ} \mathrm{C}$. The reaction mixture was kept at ${ }^{\circ} \mathrm{C}$ for $2 \mathrm{~h}$ and then quenched by $\mathrm{MeOH}$. The resulting mixture was stirred for $1 \mathrm{~h}$ after adding saturated solution of potassium sodium tartrate and extracted with EtOAc. The combined organic layers was washed by brine, dried over $\mathrm{Na}_{2} \mathrm{SO}_{4}$ and concentrated in vacuo. After purification by flash column chromatography (petroleum ether/EtOAc $=6: 1$ ), the title compound 14 was obtained as white solid in a yield of $1.80 \mathrm{~g}(3.64 \mathrm{mmol}, 95 \%)$. Mp: $74-76{ }^{\circ} \mathrm{C} ;{ }^{1} \mathrm{H}$ NMR (400 MHz, $\left.\mathrm{CDCl}_{3}\right) \delta 6.47(\mathrm{~d}, J=0.8 \mathrm{~Hz}, 2 \mathrm{H}), 4.56(\mathrm{~d}, J=6.0 \mathrm{~Hz}, 2 \mathrm{H}), 1.68-1.58(\mathrm{~m}, 1 \mathrm{H}), 1.06$ (s, $18 \mathrm{H}), 0.28(\mathrm{~s}, 12 \mathrm{H}) ;{ }^{13} \mathrm{C} \mathrm{NMR}\left(100 \mathrm{MHz}, \mathrm{CDCl}_{3}\right) \delta 156.9,142.4$, 109.7. 86.2, 64.7, 25.1, 18.4, -3.9; IR (neat): $v_{\max }\left(\mathrm{cm}^{-1}\right)=3318,2929,2857,1568,1422,1254,1092,825,780$; HRMS (ESI) $[\mathrm{M}+\mathrm{H}]+$ calculated for $\mathrm{C}_{19} \mathrm{H}_{35} \mathrm{IO}_{3} \mathrm{Si}_{2}: 495.1242$, found: 495.1240 .

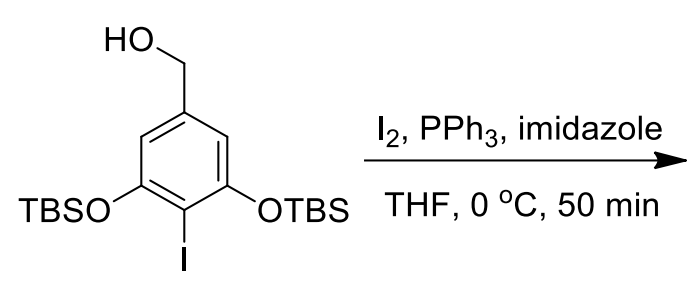

14

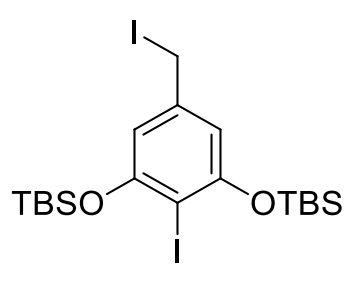

15

((2-Iodo-5-(iodomethyl)-1, 3-phenylene)bis(oxy))bis(tert-butyldimethylsilane) (15)

To a solution of $\mathbf{1 4}(1.80 \mathrm{~g}, 3.64 \mathrm{mmol})$ in THF $(20 \mathrm{~mL})$, imidazole $(0.297 \mathrm{~g}, 4.38 \mathrm{mmol})$ and $\mathrm{PPh}_{3}(1.05$ $\mathrm{g}, 4.00 \mathrm{mmol})$ were added at room temperature. The reaction mixture was cooled to $0{ }^{\circ} \mathrm{C}$, and $\mathrm{I}_{2}(1.02 \mathrm{~g}$, $4.00 \mathrm{mmol})$ in THF $(5 \mathrm{~mL})$ was added slowly over $20 \mathrm{~min}$. The reaction was kept at $0{ }^{\circ} \mathrm{C}$ for another 30 min and then quenched by a few drops of water. The resulting mixture was concentrated in vacuo to get the crude product. After purification by flash column chromatography (petroleum ether/EtOAc $=50: 1$ ), the title compound 15 was obtained as white solid in a yield of $2.06 \mathrm{~g}(3.41 \mathrm{mmol}, 94 \%)$. Mp: $84-86^{\circ} \mathrm{C}$; ${ }^{1} \mathrm{H}$ NMR $\left(400 \mathrm{MHz}, \mathrm{CDCl}_{3}\right) \delta 6.46(\mathrm{~s}, 2 \mathrm{H}), 4.31(\mathrm{~s}, 2 \mathrm{H}), 1.07$ (s, 18H), 0.29 (s, 12H); ${ }^{13} \mathrm{C} \mathrm{NMR}(100$ $\left.\mathrm{MHz}, \mathrm{CDCl}_{3}\right) \delta 156.8,140.3,111.8,87.0,25.9,18.4,4.9,-4.0 ; \mathrm{IR}\left(\right.$ neat): $v_{\max }\left(\mathrm{cm}^{-1}\right)=2929,2856,1568$, 1423, 1258, 1232, 1106, 1074, 823, 778; HRMS (ESI) $[\mathrm{M}+\mathrm{H}]{ }^{+}$calculated for $\mathrm{C}_{19} \mathrm{H}_{34} \mathrm{I}_{2} \mathrm{O}_{2} \mathrm{Si}_{2}: 605.0260$, found: 605.0261 .<smiles>CC(C)(O)Oc1cc(CI)cc([OH2+])c1I</smiles>

15

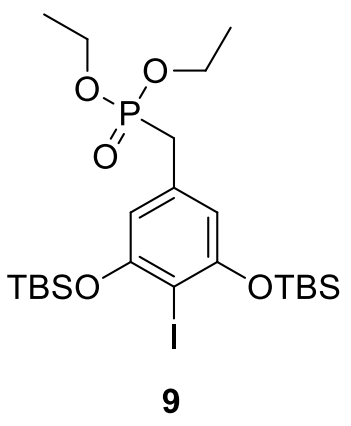

Diethyl 3, 5-bis((tert-butyldimethylsilyl)oxy)-4-iodobenzylphosphonate (9)

The compound $15(4.10 \mathrm{~g}, 6.79 \mathrm{mmol})$ and $\mathrm{P}(\mathrm{OEt})_{3}(5 \mathrm{ml})$ were added to a sealed tube, and the mixture was heated to $140{ }^{\circ} \mathrm{C}$ for $50 \mathrm{~min}$. After cooled to room temperature, the reaction mixture was purified directly by flash column chromatography (petroleum ether/EtOAc $=20: 1$ to $5: 1$ ) to afford the title compound 9 as white solid in a yield of $4.13 \mathrm{~g}(6.72 \mathrm{mmol}, 99 \%)$. Mp: 64-66 ${ }^{\circ} \mathrm{C} ;{ }^{1} \mathrm{H} \mathrm{NMR}(400 \mathrm{MHz}$, $\left.\mathrm{CDCl}_{3}\right) \delta 6.43(\mathrm{~d}, J=2.4 \mathrm{~Hz}, 2 \mathrm{H}), 4.02(\mathrm{~m}, 4 \mathrm{H}), 3.04(\mathrm{~s}, 1 \mathrm{H}), 2.99(\mathrm{~s}, 1 \mathrm{H}), 1.25(\mathrm{t}, J=7.2 \mathrm{~Hz}, 6 \mathrm{H}), 1.06$ $(\mathrm{s}, 18 \mathrm{H}), 0.28(\mathrm{~s}, 12 \mathrm{H}) ;{ }^{13} \mathrm{C} \mathrm{NMR}\left(100 \mathrm{MHz}, \mathrm{CDCl}_{3}\right) \delta 156.6,156.5,132.8,132.7,113.0,112.9,85.6$, 85.5, 62.1,62.0, 34.1, 32.8, 25.9, 18.3, 16.4, 16.3, -4.1; IR (neat): $v_{\max }\left(\mathrm{cm}^{-1}\right)=2929,2857,1567,1423$, 
1251,1230, 1083, 1025, 823, 776; HRMS (ESI) $[\mathrm{M}+\mathrm{H}]{ }^{+}$calculated for $\mathrm{C}_{23} \mathrm{H}_{44} \mathrm{IO}_{5} \mathrm{PSi}_{2}:$ : 615.1582, found: 615.1579 .

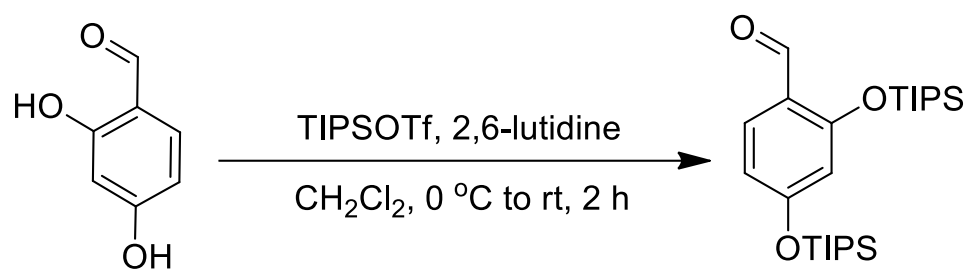

2,4-dihydroxybenzaldehyde

10

\section{2, 4-Bis((triisopropylsilyl)oxy)benzaldehyde (10)}

To a solution of 2, 4-dihydroxybenzaldehyde $(5.00 \mathrm{~g}, 36.2 \mathrm{mmol})$ in $\mathrm{CH}_{2} \mathrm{Cl}_{2}(150 \mathrm{~mL})$ was added 2, 6-lutidine $\left(13.5 \mathrm{~mL}, 116 \mathrm{mmol}\right.$ ) at $0^{\circ} \mathrm{C}$, after stirring for $5 \mathrm{~min}$, TIPSOTf ( $23.4 \mathrm{~mL}, 86.9 \mathrm{mmol}$ ) was added dropwise at $0{ }^{\circ} \mathrm{C}$. The reaction mixture was allowed to stir at room temperature for $2 \mathrm{~h}$ and then diluted with water. The resulting mixture was extracted with $\mathrm{CH}_{2} \mathrm{Cl}_{2}$ and washed by brine. The organic layers were dried over $\mathrm{Na}_{2} \mathrm{SO}_{4}$ and concentrated in vacuo. After purification by flash column chromatography (petroleum ether/EtOAc $=40: 1$ ), the title compound $\mathbf{1 0}$ was obtained as yellow oil in a yield of $14.8 \mathrm{~g}(32.8 \mathrm{mmol}, 91 \%) .{ }^{1} \mathrm{H}$ NMR $\left(400 \mathrm{MHz}, \mathrm{CDCl}_{3}\right) \delta 10.37(\mathrm{~d}, J=0.8 \mathrm{~Hz}, 1 \mathrm{H}), 7.71(\mathrm{~d}, J=$ $8.4 \mathrm{~Hz}, 1 \mathrm{H}), 6.52(\mathrm{ddd}, J=0.8,2.0,8.4 \mathrm{~Hz}, 1 \mathrm{H}), 6.35(\mathrm{~d}, J=2.0 \mathrm{~Hz}, 1 \mathrm{H}), 1.36-1.22(\mathrm{~m}, 6 \mathrm{H}), 1.16-1.05$ $(\mathrm{m}, 36 \mathrm{H}) ;{ }^{13} \mathrm{C}$ NMR $\left(100 \mathrm{MHz}, \mathrm{CDCl}_{3}\right) \delta 188.7,163.0,161.1,129.8,121.3,114.4,110.4,18.1,17.8$, 17.7, 17.6, 13.0, 12.6, 12.3; IR (neat): $v_{\max }\left(\mathrm{cm}^{-1}\right)=2943,2866,1685,1591,1273,1185,995,880,670$; HRMS (ESI) $[\mathrm{M}+\mathrm{H}]{ }^{+}$calculated for $\mathrm{C}_{25} \mathrm{H}_{46} \mathrm{O}_{3} \mathrm{Si}_{2}: 451.3058$, found: 451.3051 .<smiles>CCOc1cc(CP(=O)(OCC)OCC)cc(OC(C)(C)C)c1I</smiles>

9

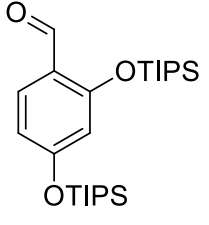

10

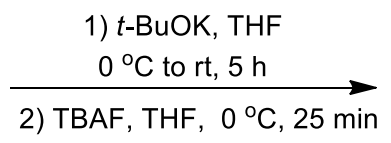<smiles>CC(=CC=Cc1ccc(O)cc1O)CO</smiles>

20

\section{(E)-5-(2, 4-dihydroxystyryl)-2-iodobenzene-1, 3-diol (20)}

To a solution of $\mathbf{9}(0.450 \mathrm{~g}, 0.732 \mathrm{mmol})$ and $\mathbf{1 0}(1.48 \mathrm{~g}, 3.29 \mathrm{mmol})$ in THF $(8 \mathrm{~mL})$ was added $t$-BuOK $(0.246 \mathrm{~g}, 2.20 \mathrm{mmol})$ at $0{ }^{\circ} \mathrm{C}$, The reaction mixture was slowly warmed to room temperature and quenched by water after $5 \mathrm{~h}$. The resulting mixture was extracted with EtOAc and the combined organic layers was washed by brine, dried over $\mathrm{Na}_{2} \mathrm{SO}_{4}$ and concentrated in vacuo to get an oil mixture. The mixture was filtrated through a pad of silica gel (petroleum ether) to afford the crude product before being used directly in the next step.

The crude product was dissolved in THF $(8 \mathrm{~mL})$ and TBAF $(4.39 \mathrm{~mL}, 4.39 \mathrm{mmol})$ was added dropwise at $0{ }^{\circ} \mathrm{C}$. The reaction mixture was stirred for $25 \mathrm{~min}$ at $0{ }^{\circ} \mathrm{C}$ and quenched by saturated $\mathrm{NH}_{4} \mathrm{Cl}$ solution. The resulting mixture was extracted with EtOAc, and the combined organic layers were washed by brine, dried over $\mathrm{Na}_{2} \mathrm{SO}_{4}$ and concentrated in vacuo to afford the crude product. After purification by flash column chromatography (petroleum ether/EtOAc $=1: 1$ ), the title compound $\mathbf{2 0}$ was obtained as gray foams in a yield of $0.182 \mathrm{~g}(0.492 \mathrm{mmol}, 67 \%) .{ }^{1} \mathrm{H}$ NMR (400 MHz, acetone- $\left.d_{6}\right) \delta 8.77$ (br.s, $\left.2 \mathrm{H}\right), 8.59$ (br.s, 1H), 8.39 (br.s, 1H), 7.41 (d, $J=8.8 \mathrm{~Hz}, 1 \mathrm{H}), 7.37$ (d, $J=16.4 \mathrm{~Hz}, 1 \mathrm{H}), 6.87$ (d, $J=16.4 \mathrm{~Hz}, 1 \mathrm{H})$, $6.67(\mathrm{~s}, 2 \mathrm{H}), 6.44(\mathrm{~d}, J=2.4 \mathrm{~Hz}, 1 \mathrm{H}), 6.38(\mathrm{dd}, J=2.4,8.4 \mathrm{~Hz}, 1 \mathrm{H}) ;{ }^{13} \mathrm{C}$ NMR $\left(100 \mathrm{MHz}\right.$, acetone- $\left.d_{6}\right) \delta$ $159.3,158.8,157.0,141.4,128.3,125.1,125.0,117.0,108.5,104.8,103.5,73.0 ;$ IR (neat): $v_{\max }\left(\mathrm{cm}^{-1}\right)=$ 
$3331,1586,1516,1421,1264,1164,1035,972,821$; HRMS (ESI) $[\mathrm{M}+\mathrm{H}]{ }^{+}$calculated for $\mathrm{C}_{14} \mathrm{H}_{11} \mathrm{IO}_{4}$ : 370.9775, found: 370.9776 .<smiles>Oc1ccc(/C=C/c2cc(O)c(I)c(O)c2)c(O)c1</smiles>

20<smiles>COc1ccc(/C=C/c2cc(OC)c(I)c(OC)c2)c(OC)c1</smiles>

21

(E)-5-(2, 4-bis(methoxymethoxy)styryl)-2-iodo-1,3-bis(methoxymethoxy)benzene (21)

To a solution of 20 (113 mg, $0.305 \mathrm{mmol})$ and DIPEA (303 $\mu \mathrm{L}, 1.83 \mathrm{mmol})$ in $\mathrm{CH}_{2} \mathrm{Cl}_{2}(1.5 \mathrm{~mL})$ was added $\mathrm{MOMCl}(102 \mu \mathrm{L}, 1.34 \mathrm{mmol})$ dropwise at $0{ }^{\circ} \mathrm{C}$, the resulting mixture was slowly warmed to room temperature and stirred overnight. After quenched by water, the mixture was extracted with $\mathrm{CH}_{2} \mathrm{Cl}_{2}$. The combined organic layers were washed by brine, dried over $\mathrm{Na}_{2} \mathrm{SO}_{4}$ and concentrated in vacuo to afford the crude product. After purification by flash column chromatography (petroleum ether/ $\mathrm{CH}_{2} \mathrm{Cl}_{2}=1: 1$ ), the title compound 21 was obtained as white solid in a yield of $80.8 \mathrm{mg}(0.148 \mathrm{mmol}, 48 \%)$. Mp: 129-131 ${ }^{\circ} \mathrm{C} ;{ }^{1} \mathrm{H}$ NMR $\left(400 \mathrm{MHz}, \mathrm{CDCl}_{3}\right) \delta 7.49(\mathrm{~d}, J=8.8 \mathrm{~Hz}, 1 \mathrm{H}), 7.38(\mathrm{~d}, J=16.4 \mathrm{~Hz}, 1 \mathrm{H}), 6.94(\mathrm{~d}, J$ $=16.4 \mathrm{~Hz}, 1 \mathrm{H}), 6.91(\mathrm{~s}, 2 \mathrm{H}), 6.84(\mathrm{~d}, J=2.4 \mathrm{~Hz}, 1 \mathrm{H}), 6.72(\mathrm{dd}, J=2.4,8.4 \mathrm{~Hz}, 1 \mathrm{H}), 5.30(\mathrm{~s}, 4 \mathrm{H}), 5.24$ $(\mathrm{s}, 2 \mathrm{H}), 5.18(\mathrm{~s}, 2 \mathrm{H}), 3.55(\mathrm{~s}, 6 \mathrm{H}), 3.53(\mathrm{~s}, 3 \mathrm{H}), 3.49(\mathrm{~s}, 3 \mathrm{H}) ;{ }^{13} \mathrm{C} \mathrm{NMR}\left(100 \mathrm{MHz}, \mathrm{CDCl}_{3}\right) \delta 158.2,157.5$, 155.8, 140.4, 127.5, 126.9, 124.5, 120.9, 109.6, 106.7, 104.0, 95.1, 94.5, 79.0, 56.6, 56.4, 56.2; IR (neat): $v_{\max }\left(\mathrm{cm}^{-1}\right)=2953,2905,1569,1265,1151,1043,1007,921$; HRMS (ESI) $[\mathrm{M}+\mathrm{H}]{ }^{+}$calculated for $\mathrm{C}_{22} \mathrm{H}_{27} \mathrm{IO}_{8}: 547.0823$, found: 547.0828.

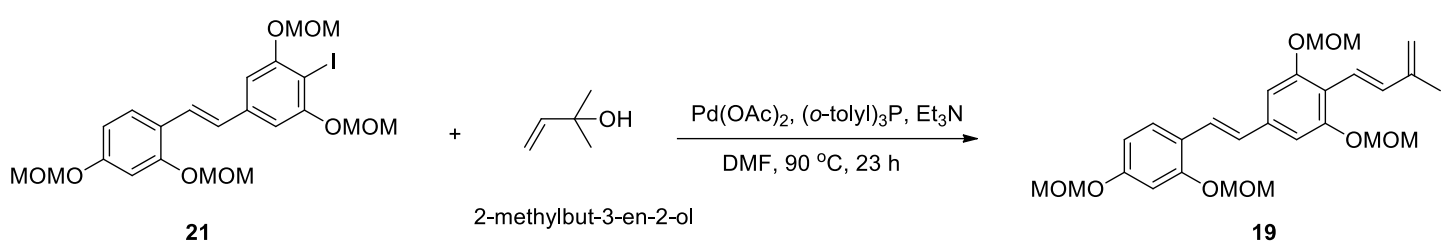

5-((E)-2, 4-bis(methoxymethoxy)styryl)-1， 3-bis(methoxymethoxy)-2-((E)-3-methylbuta-1, 3dien-1-yl)benzene (19)

To a solution of 21 (100 mg, $0.183 \mathrm{mmol})$ and 2-methylbut-3-en-2-ol $(95.7 \mu \mathrm{L}, 0.915 \mathrm{mmol})$ in DMF $(0.75 \mathrm{~mL})$ was added $(o \text {-tolyl })_{3} \mathrm{P}(11.1 \mathrm{mg}, 0.0366 \mathrm{mmol})$ and $\mathrm{Et}_{3} \mathrm{~N}(31.8 \mu \mathrm{L}, 0.229 \mathrm{mmol})$. The solution was bubbled with Argon for $30 \mathrm{~min}$ and then $\mathrm{Pd}(\mathrm{OAc})_{2}(2.1 \mathrm{mg}, 0.00915 \mathrm{mmol})$ was added. The resulting mixture was heated to $90{ }^{\circ} \mathrm{C}$ for $23 \mathrm{~h}$ and then cooled down to the room temperature. The reaction mixture was diluted with EtOAc and washed by brine. The combined organic layers were dried over $\mathrm{Na}_{2} \mathrm{SO}_{4}$ and concentrated in vacuo to afford the crude product. After purification by flash column chromatography (petroleum ether/EtOAc $=15: 1$ ), the title compound 19 was obtained as yellow solid in a yield of $67.8 \mathrm{mg}(0.140 \mathrm{mmol}, 76 \%)$. Mp: $104-106{ }^{\circ} \mathrm{C} ;{ }^{1} \mathrm{H}$ NMR $\left(400 \mathrm{MHz}, \mathrm{CDCl}_{3}\right) \delta 7.50(\mathrm{~d}, J=8.4$ $\mathrm{Hz}, 1 \mathrm{H}), 7.35(\mathrm{~d}, J=16.4 \mathrm{~Hz}, 1 \mathrm{H}), 7.34(\mathrm{~d}, J=16.4 \mathrm{~Hz}, 1 \mathrm{H}), 6.95(\mathrm{~s}, 2 \mathrm{H}), 6.93(\mathrm{~d}, J=15.2 \mathrm{~Hz}, 1 \mathrm{H})$, $6.86(\mathrm{~d}, J=16.8 \mathrm{~Hz}, 1 \mathrm{H}), 6.84(\mathrm{~d}, J=2.4 \mathrm{~Hz}, 1 \mathrm{H}), 6.73(\mathrm{dd}, J=2.4,8.4 \mathrm{~Hz}, 1 \mathrm{H}), 5.28(\mathrm{~s}, 4 \mathrm{H}), 5.24(\mathrm{~s}$, $2 \mathrm{H}), 5.18(\mathrm{~s}, 2 \mathrm{H}), 5.08(\mathrm{~s}, 1 \mathrm{H}), 5.06(\mathrm{~s}, 1 \mathrm{H}), 3.52(\mathrm{~s}, 9 \mathrm{H}), 3.49(\mathrm{~s}, 3 \mathrm{H}), 2.01(\mathrm{~s}, 3 \mathrm{H}) ;{ }^{13} \mathrm{C} \mathrm{NMR}(100 \mathrm{MHz}$, $\left.\mathrm{CDCl}_{3}\right) \delta 158.0,156.2,155.7,143.7,138.2,135.8,127.5,127.3,123.6,121.3,120.0,116.7,116.3,109.6$, 107.0, 104.0, 95.1, 95.0, 94.6, 56.4, 56.3,56.2, 18.4; IR (neat): $v_{\max }\left(\mathrm{cm}^{-1}\right)=2952,2905,1592,1557$, 1432, 1261, 1207, 1151, 1077, 1043, 1010, 922; HRMS (ESI) $[\mathrm{M}+\mathrm{H}]+$ calculated for $\mathrm{C}_{27} \mathrm{H}_{34} \mathrm{O}_{8}$ : 486.2248, found: 486.2254 . 


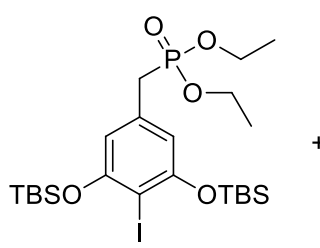

9

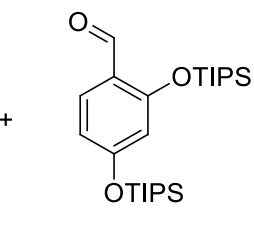

10

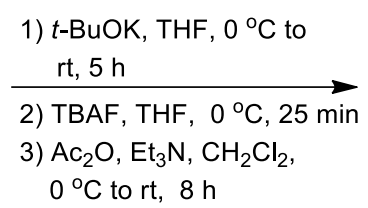

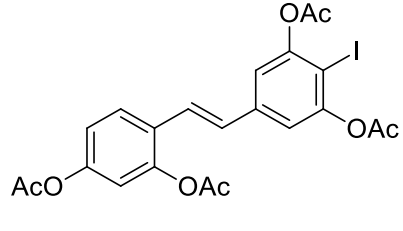

8

\section{(E)-4-(3, 5-diacetoxy-4-iodostyryl)-1, 3-phenylene diacetate (8)}

To a solution of $\mathbf{9}(1.51 \mathrm{~g}, 2.46 \mathrm{mmol})$ and $\mathbf{1 0}(5.00 \mathrm{~g}, 11.1 \mathrm{mmol})$ in THF $(24 \mathrm{~mL})$ was added $t$-BuOK $(0.830 \mathrm{~g}, 7.39 \mathrm{mmol})$ at $0{ }^{\circ} \mathrm{C}$, The reaction mixture was slowly warmed to room temperature and quenched by water after $5 \mathrm{~h}$. The resulting mixture was extracted with EtOAc and the combined organic layers was washed by brine, dried over $\mathrm{Na}_{2} \mathrm{SO}_{4}$ and concentrated in vacuo to get an oil mixture. The mixture was filtrated through a pad of silica gel (petroleum ether) to afford the crude product before being used directly in the next step.

The crude product was dissolved in THF (24 mL) and TBAF (14.8 mL, $14.8 \mathrm{mmol})$ was added dropwise at $0{ }^{\circ} \mathrm{C}$. The reaction mixture was stirred for $25 \mathrm{~min}$ and quenched by saturated $\mathrm{NH}_{4} \mathrm{Cl}$ solution. The resulting mixture was extracted with EtOAc, and the combined organic layers were washed by brine, dried over $\mathrm{Na}_{2} \mathrm{SO}_{4}$ and concentrated in vacuo to afford the crude product.

The crude product from second step and $\mathrm{Et}_{3} \mathrm{~N}(4.10 \mathrm{~mL}, 29.5 \mathrm{mmol})$ were dissolved in $\mathrm{CH}_{2} \mathrm{Cl}_{2}(24 \mathrm{~mL})$ at $0{ }^{\circ} \mathrm{C}$, and then $\mathrm{Ac}_{2} \mathrm{O}(1.39 \mathrm{~mL}, 14.8 \mathrm{mmol})$ was added slowly. The resulting mixture was warmed to room temperature slowly. After $8 \mathrm{~h}$, the reaction mixture was diluted with water and extracted with EtOAc. The combined organic layers were washed by saturated $\mathrm{NH}_{4} \mathrm{Cl}$ solution, followed by saturated $\mathrm{NaHCO}_{3}$ solution and brine, dried over $\mathrm{Na}_{2} \mathrm{SO}_{4}$ and concentrated in vacuo to afford the crude product. After purification by flash column chromatography (petroleum ether/EtOAc $=5: 1$ ), the title compound 8 was obtained as white solid in a yield of $0.754 \mathrm{~g}\left(1.40 \mathrm{mmol}, 57 \%\right.$ in three steps). Mp: $165-167{ }^{\circ} \mathrm{C} ;{ }^{1} \mathrm{H}$ NMR (400 MHz, $\left.\mathrm{CDCl}_{3}\right) \delta 7.59(\mathrm{~d}, J=8.8 \mathrm{~Hz}, 1 \mathrm{H}), 7.09$ (s, 2H), $7.08(\mathrm{~d}, J=16.4 \mathrm{~Hz}, 1 \mathrm{H}), 7.02(\mathrm{dd}, J$ $=2.4,8.4 \mathrm{~Hz}, 1 \mathrm{H}), 6.95(\mathrm{~d}, J=1.6 \mathrm{~Hz}, 1 \mathrm{H}), 6.93(\mathrm{~d}, J=16.4 \mathrm{~Hz}, 1 \mathrm{H}), 2.39(\mathrm{~s}, 6 \mathrm{H}), 2.35(\mathrm{~s}, 3 \mathrm{H}), 2.29(\mathrm{~s}$, $3 \mathrm{H}) ;{ }^{13} \mathrm{C}$ NMR $\left(100 \mathrm{MHz}, \mathrm{CDCl}_{3}\right) \delta 168.9,168.7,168.3,152.7,150.6,148.5,139.4,128.6,127.2,126.8$, 124.1, 119.5, 118.3, 116.4, 87.1, 21.2, 21.1, 21.0; IR (neat): $v_{\max }\left(\mathrm{cm}^{-1}\right)$ 1764, 1367, 1181, 1144, 1037, 894, 725; HRMS (ESI) $[\mathrm{M}+\mathrm{H}]{ }^{+}$calculated for $\mathrm{C}_{22} \mathrm{H}_{19} \mathrm{IO}_{8}: 539.0203$, found: 539.0211 .
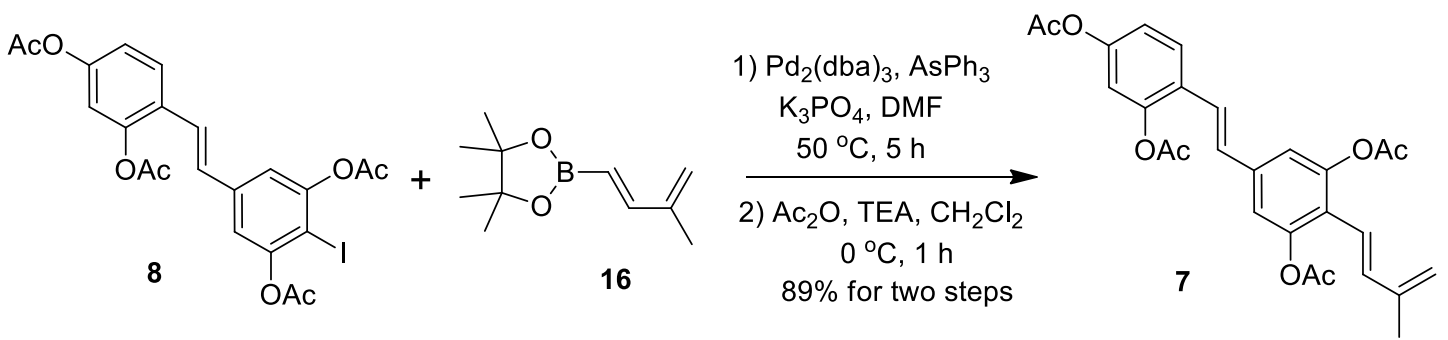

\section{4-((E)-3, 5-diacetoxy-4-((E)-3-methylbuta-1, 3-dien-1-yl)styryl)-1,3-phenylene diacetate (7)}

To a solution of $8(181 \mathrm{mg}, 0.336 \mathrm{mmol})$ and $\mathbf{1 6}^{2}(261 \mathrm{mg}, 1.35 \mathrm{mmol})$ in DMF (5 mL) was added $\mathrm{AsPh}_{3}(14.4 \mathrm{mg}, 0.0471 \mathrm{mmol})$ and $\mathrm{K}_{3} \mathrm{PO}_{4}(714 \mathrm{mg}, 3.36 \mathrm{mmol})$. The solution was bubbled with Argon for $30 \mathrm{~min}$ and then $\mathrm{Pd}_{2}(\mathrm{dba})_{3}(21.6 \mathrm{mg}, 0.0235 \mathrm{mmol})$ was added. The resulting mixture was heated to $50{ }^{\circ} \mathrm{C}$ for $5 \mathrm{~h}$ and then filtrated through a pad of celite. The filtrate was diluted with EtOAc and washed by brine. The combined organic layers were dried over $\mathrm{Na}_{2} \mathrm{SO}_{4}$ and concentrated in vacuo to afford the

2 Known Compound 16 was synthesized according to literature : Cannillo, A.; Norsikian, S.; Retailleau, P.;

Dau, M. T. H.; Iorga, B. I.; Beau, J. Chem. Eur. J. 2013, 19, 9127. 
crude product.

The crude product and $\mathrm{Et}_{3} \mathrm{~N}(0.467 \mathrm{ml}, 3.36 \mathrm{mmol})$ were dissolved in $\mathrm{CH}_{2} \mathrm{Cl}_{2}(6 \mathrm{~mL})$ at $0{ }^{\circ} \mathrm{C}$, and then $\mathrm{Ac}_{2} \mathrm{O}(0.190 \mathrm{~mL}, 2.02 \mathrm{mmol})$ was added slowly. The reaction was kept at $0{ }^{\circ} \mathrm{C}$ for $1 \mathrm{~h}$ and then quenched by water. The mixture was extracted with EtOAc and washed by brine. The combined organic layers were dried over $\mathrm{Na}_{2} \mathrm{SO}_{4}$ and concentrated in vacuo to afford the crude product. After purification by flash column chromatography (petroleum ether/EtOAc $=5: 1$ ), the title compound 7 was obtained as yellow solid in a yield of $143 \mathrm{mg}(0.299 \mathrm{mmol}, 89 \%)$. Mp: 144-146 ${ }^{\circ} \mathrm{C} ;{ }^{1} \mathrm{H}$ NMR $\left(400 \mathrm{MHz}, \mathrm{CDCl}_{3}\right) \delta$ $7.59(\mathrm{~d}, J=8.4 \mathrm{~Hz}, 1 \mathrm{H}), 7.08(\mathrm{~s}, 2 \mathrm{H}), 7.04,(\mathrm{~d}, J=16.0 \mathrm{~Hz}, 1 \mathrm{H}), 7.02(\mathrm{dd}, J=2.4,8.4 \mathrm{~Hz}, 1 \mathrm{H}), 6.95(\mathrm{~d}$, $J=2.0 \mathrm{~Hz}, 1 \mathrm{H}), 6.93(\mathrm{~d}, J=16.0 \mathrm{~Hz}, 1 \mathrm{H}), 6.90(\mathrm{~d}, J=16.8 \mathrm{~Hz}, 1 \mathrm{H}), 6.29(\mathrm{~d}, J=16.4 \mathrm{~Hz}, 1 \mathrm{H}), 5.12(\mathrm{~s}$, $1 \mathrm{H}), 5.10(\mathrm{~s}, 1 \mathrm{H}), 2.35(\mathrm{~s}, 3 \mathrm{H}), 2.30(\mathrm{~s}, 6 \mathrm{H}), 2.27(\mathrm{~s}, 3 \mathrm{H}), 1.92(\mathrm{~s}, 3 \mathrm{H}) ;{ }^{13} \mathrm{C} \mathrm{NMR}\left(100 \mathrm{MHz}, \mathrm{CDCl}_{3}\right) \delta$ $168.8,168.7,168.6,150.3,149.2,148.3,142.0,137.8,137.0,129.1,127.1,127.0,123.4,123.0,119.4$, 118.7, 118.5, 117.9, 116.3, 20.9, 20.8, 20.7, 17.9; IR (neat): $v_{\max }\left(\mathrm{cm}^{-1}\right) 1765,1426,1370,1186,1043$, 1016; HRMS (ESI) $[\mathrm{M}+\mathrm{H}]^{+}$calculated for $\mathrm{C}_{27} \mathrm{H}_{26} \mathrm{O}_{8}: 479.1700$, found: 479.1708 .
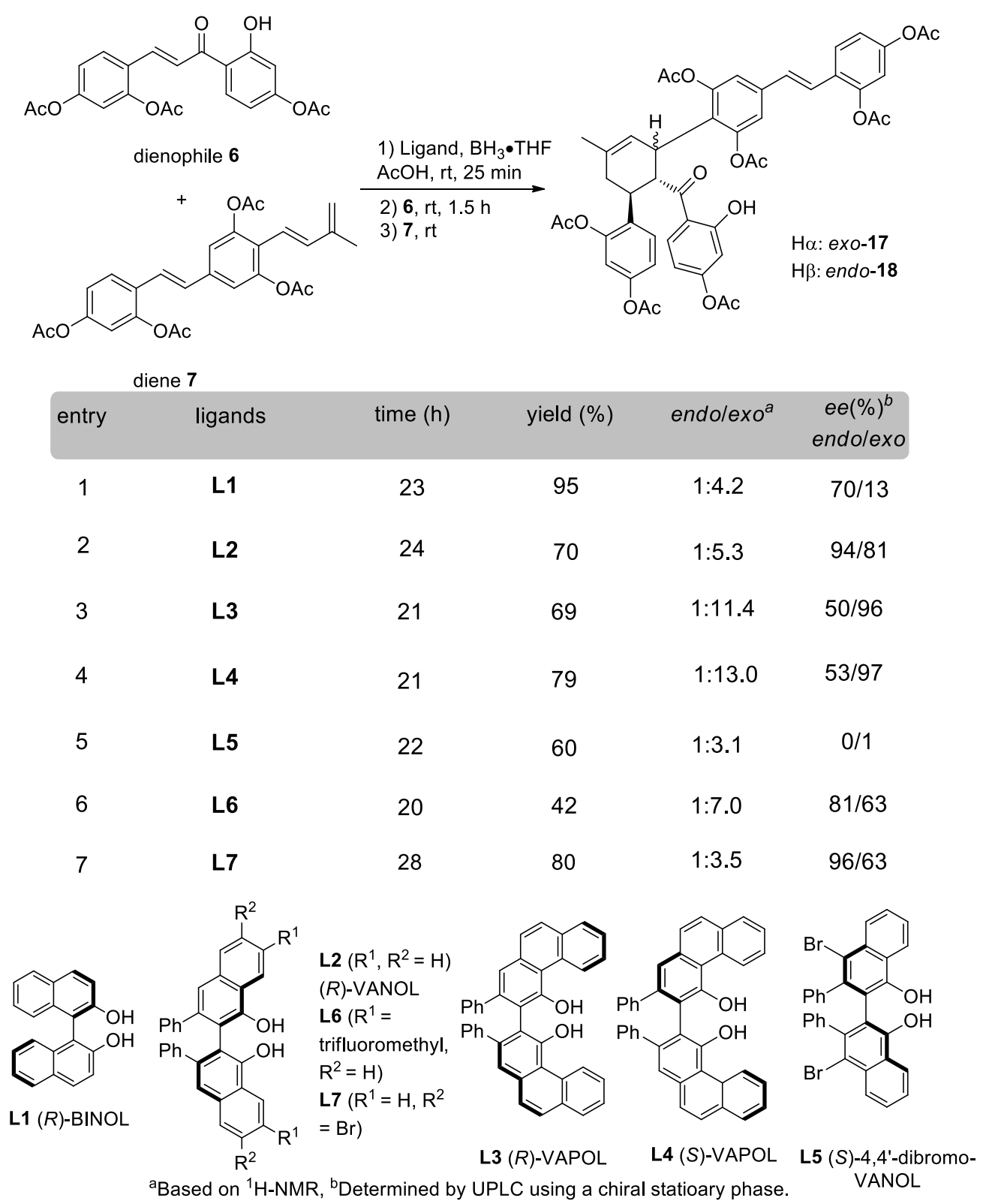


\section{General procedure for the asymmetric Diels-Alder reaction}

To a solution of ligand (2.5 eq) in THF (0.2 M) was added $\mathrm{BH}_{3} \bullet$ THF (1.2 eq) and AcOH (1.2 eq) sequentially. The resulting mixture was stirred at room temperature for $25 \mathrm{~min}$, and then concentrated to dryness and further dried under high vacuum at room temperature for $30 \mathrm{~min}$. The resulting solid was dissolved in dry THF $(0.1 \mathrm{M})$, and then pre-activated $5 \AA$ molecular sieve (20 weight equiv to 6) and the dienophile 6 (1.0 eq) were added to the solution. The resulting solution was stirred at room temperature for $1.5 \mathrm{~h}$ before the diene 7 ( $1.05 \mathrm{eq})$ was added to the reaction mixture. When full conversion was obtained, as observed by TLC, the reaction mixture was quenched by addition of $\mathrm{H}_{2} \mathrm{O}$ (15.0 eq) and filtered through a pad of celite. The celite was further washed with EtOAc, and the organic filtrates were collected and concentrated in vacuo. The crude product was filtrated through a pad of silica gel to get the mixture of exo-17 and endo-18 before determination of the ratio of endo/exo by NMR. Further purification was achieved by flash column chromatography (petroleum ether/EtOAc $=5: 1$ to 2:1), the exo-17 and endo-18 were obtained as yellow solid in a total yield of $42-95 \%$.

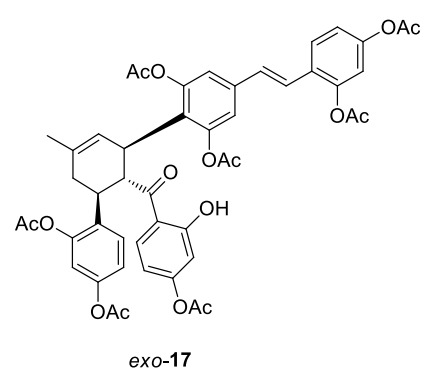

\section{Exo-17}

To a solution of $S$-VAPOL $(56.3 \mathrm{mg}, 0.105 \mathrm{mmol})$ in THF $(0.2 \mathrm{~mL})$ was added $\mathrm{BH}_{3}{ }^{-T H F}(50.2 \mu \mathrm{L}$, $0.0502 \mathrm{mmol})$ and $\mathrm{AcOH}(2.9 \mu \mathrm{L}, 0.0502 \mathrm{mmol})$ sequentially. The resulting mixture was stirred at room temperature for $25 \mathrm{~min}$, and then concentrated to dryness and further dried under high vacuum at room temperature for $30 \mathrm{~min}$. The resulting solid was dissolved in dry THF $(0.4 \mathrm{~mL})$, and then pre-activated $5 \AA$ molecular sieve $(332 \mathrm{mg})$ and the dienophile $6(16.6 \mathrm{mg}, 0.0418 \mathrm{mmol})$ were added to the solution. The resulting solution was stirred at room temperature for $1.5 \mathrm{~h}$ before the diene 7 (21.0 $\mathrm{mg}, 0.0439$ mmol) was added to the reaction mixture. The reaction mixture was quenched by addition of $\mathrm{H}_{2} \mathrm{O}(11.3$ $\mu \mathrm{L}, 15.0 \mathrm{eq})$ after $21 \mathrm{~h}$ and filtered through a pad of celite. The celite was further washed with EtOAc, and the organic filtrates were collected and concentrated in vacuo. The crude product was filtrated through a pad of silica gel to get the mixture of exo-17 and endo-18 before determination of the ratio of endo/exo by NMR. Further purification was achieved by flash column chromatography (petroleum ether/EtOAc $=5: 1$ to 2:1) to afford the exo-17 as yellow solid in a yield of $26.1 \mathrm{mg}(0.0298 \mathrm{mmol}, 71 \%)$ and endo-18 as yellow solid in a yield of $2.7 \mathrm{mg}$ ( $0.00308 \mathrm{mmol}, 7 \%) . \mathrm{Mp}: 129-131{ }^{\circ} \mathrm{C} ;[\alpha]^{25} \mathrm{D}-227(\mathrm{c}$ $0.10 \mathrm{MeOH}) ;{ }^{1} \mathrm{H}$ NMR $\left(400 \mathrm{MHz}, \mathrm{CDCl}_{3}\right) \delta 12.30(\mathrm{~s}, 1 \mathrm{H}), 7.56(\mathrm{~d}, J=8.4 \mathrm{~Hz}, 1 \mathrm{H}), 7.33(\mathrm{~d}, J=9.2 \mathrm{~Hz}$, $1 \mathrm{H}), 7.17(\mathrm{~d}, J=8.4 \mathrm{~Hz}, 1 \mathrm{H}), 6.99(\mathrm{dd}, J=2.0,8.4 \mathrm{~Hz}, 1 \mathrm{H}), 6.96(\mathrm{~s}, 1 \mathrm{H}), 6.92(\mathrm{~d}, J=16.4 \mathrm{~Hz}, 1 \mathrm{H}), 6.92$ $(\mathrm{d}, J=2.0 \mathrm{~Hz}, 1 \mathrm{H}), 6.84-6.78(\mathrm{~m}, 4 \mathrm{H}), 6.49(\mathrm{~d}, J=2.0 \mathrm{~Hz}, 1 \mathrm{H}), 6.29(\mathrm{dd}, J=2.0,8.8 \mathrm{~Hz}, 1 \mathrm{H}), 5.36(\mathrm{~s}$, 1H), 4.29 (br.s, 1H), 4.05 (d, $J=9.6 \mathrm{~Hz}, 1 \mathrm{H}$ ), 3.74 (br.s, 1H), 2.41 (s, 3H), 2.33 (s, 3H), 2.32 (s, 3H), 2.28 (s, 4H), 2.27 (s, 4H), 2.19 (s, 3H), 2.17 (s, 3H), 1.78 (s, 3H); ${ }^{13} \mathrm{C} \mathrm{NMR} \mathrm{(100} \mathrm{MHz,} \mathrm{CDCl}_{3}$ ) $\delta 207.7$, $169.2,168.9,168.8,168.7,168.5,168.0,163.8,156.4,150.3,150.0,149.3,149.1,148.4,148.3,137.4$, $132.8,131.9,130.8,129.0,127.1,127.0,126.0,123.2,123.1,119.5,119.4,119.3,118.3,118.2,116.4$, $116.3,112.0,110.3,48.4,39.5,37.4,35.6,23.2,21.1,21.0,21.0,21.0,20.9,20.8$; IR (neat): $v_{\max }\left(\mathrm{cm}^{-1}\right)$ 1766, 1632, 1368, 1183, 1145, 1013, 902, 729; HRMS (ESI) $[\mathrm{M}+\mathrm{H}]+$ calculated for $\mathrm{C}_{48} \mathrm{H}_{44} \mathrm{O}_{16}$ : 877.2702, found: 877.2691. The exo-isomer 17 ( $S$-VAPOL as chiral ligand): 97\% ee (HPLC conditions: 
Chiralcel AD-H column, hexane $/ i-\mathrm{PrOH}=60 / 40,1.0 \mathrm{~mL} / \mathrm{min}, \lambda=280 \mathrm{~nm}, t_{R}$ (major) $=21.6 \mathrm{~min}, t_{R}$ (minor) $=13.4 \mathrm{~min})$. The enantiomer of exo-isomer 17 ( $R$-VAPOL as chiral ligand): $-95 \%$ ee (HPLC conditions: Chiralcel AD-H column, hexane $/ i-\mathrm{PrOH}=60 / 40,1.0 \mathrm{~mL} / \mathrm{min}, \lambda=280 \mathrm{~nm}, t_{R}$ (major) $=11.3$ $\left.\min , t_{R}(\operatorname{minor})=18.7 \mathrm{~min}\right)$.

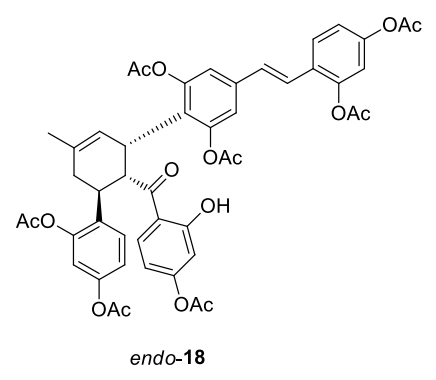

\section{Endo-18}

To a solution of $R$-VANOL ( $283 \mathrm{mg}, 0.646 \mathrm{mmol})$ in THF $(1.2 \mathrm{~mL})$ was added $\mathrm{BH}_{3}$-THF $(310 \mu \mathrm{L}, 0.310$ $\mathrm{mmol})$ and $\mathrm{AcOH}(17.7 \mu \mathrm{L}, 0.310 \mathrm{mmol})$ sequentially. The resulting mixture was stirred at room temperature for $25 \mathrm{~min}$, and then concentrated to dryness and further dried under high vacuum at room temperature for $30 \mathrm{~min}$. The resulting solid was dissolved in dry THF $(2.4 \mathrm{~mL})$, and then pre-activated $5 \AA$ molecular sieve $(2.06 \mathrm{~g})$ and the dienophile $\mathbf{6}(103 \mathrm{mg}, 0.258 \mathrm{mmol})$ were added to the solution. The resulting solution was stirred at room temperature for $1.5 \mathrm{~h}$ before the diene 7 (130 $\mathrm{mg}, 0.271 \mathrm{mmol})$ was added to the reaction mixture. The reaction mixture was quenched by addition of $\mathrm{H}_{2} \mathrm{O}(69.8 \mu \mathrm{L}$, $15.0 \mathrm{eq}$ ) after $24 \mathrm{~h}$ and filtered through a pad of celite. The celite was further washed with EtOAc, and the organic filtrates were collected and concentrated in vacuo. The crude product was filtrated through a pad of silica gel to get the mixture of exo-17 and endo-18 before determination of the ratio of endo/exo by NMR. Further purification was achieved by flash column chromatography (petroleum ether /EtOAc $=$ 5:1 to 2:1) to afford the exo-17 as yellow solid in a yield of $138 \mathrm{mg}(0.158 \mathrm{mmol}, 61 \%)$ and endo-18 as yellow solid in a yield of $24 \mathrm{mg}(0.0274 \mathrm{mmol}, 11 \%)$. Mp: 122-124 ${ }^{\circ} \mathrm{C} ;[\alpha]^{26} \mathrm{D}+92(\mathrm{c} 0.095 \mathrm{MeOH}) ;{ }^{1} \mathrm{H}$ NMR $\left(400 \mathrm{MHz}, \mathrm{CDCl}_{3}\right) \delta 12.58(\mathrm{~s}, 1 \mathrm{H}), 7.56(\mathrm{~d}, J=8.8 \mathrm{~Hz}, 1 \mathrm{H}), 7.41(\mathrm{~d}, J=8.8 \mathrm{~Hz}, 1 \mathrm{H}), 7.26(\mathrm{~d}, J=$ $8.4 \mathrm{~Hz}, 1 \mathrm{H}), 7.01(\mathrm{~d}, J=2.4 \mathrm{~Hz}, 1 \mathrm{H}), 6.99(\mathrm{~d}, J=2.4 \mathrm{~Hz}, 1 \mathrm{H}), 6.93-6.88(\mathrm{~m}, 4 \mathrm{H}), 6.81(\mathrm{~d}, J=16.4 \mathrm{~Hz}$, 1H), 6.64 (br.s, 1H), 6.60 (d, $J=2.4 \mathrm{~Hz}, 1 \mathrm{H}), 6.27(\mathrm{dd}, J=2.0,8.8 \mathrm{~Hz}, 1 \mathrm{H}), 5.34(\mathrm{~s}, 1 \mathrm{H}), 3.90(\mathrm{~m}, 1 \mathrm{H})$, $3.83(\mathrm{dd}, J=4.8,6.0 \mathrm{~Hz}, 1 \mathrm{H}), 3.73(\mathrm{~m}, 1 \mathrm{H}), 3.10(\mathrm{dd}, J=7.2,19.2 \mathrm{~Hz}, 1 \mathrm{H}), 2.34(\mathrm{~s}, 3 \mathrm{H}), 2.28(\mathrm{~s}, 6 \mathrm{H})$, 2.23 (m, 1H), 2.19 ((s, 3H), 2.17 (br.s, 3H), 2.14 (s, 3H), 1.87 (s, 3H), 1.75 (s, 3H); ${ }^{13} \mathrm{C} \mathrm{NMR} \mathrm{(100} \mathrm{MHz,}$ $\left.\mathrm{CDCl}_{3}\right) \delta 206.6,169.1,168.9,168.8,168.2,163.9,156.2,150.3,149.5,148.4,148.3,137.5,134.4,134.0$, 131.4, 129.1, 128.0, 127.2, 127.1, 125.1, 123.1, 120.8, 119.6, 119.5, 118.6, 116.4, 116.3, 112.1, 110.6, 46.3, 33.9, 33.7, 32.6, 23.4, 21.1, 21.1, 21.0, 20.9; IR (neat): $v_{\max }\left(\mathrm{cm}^{-1}\right) 1768,1634,1498,1369,1193$, 1146, 1015, 904; HRMS (ESI) $[\mathrm{M}+\mathrm{H}]+{ }^{+}$calculated for $\mathrm{C}_{48} \mathrm{H}_{44} \mathrm{O}_{16}$ : 877.2702, found: 877.2715. The endo-isomer 18 ( $R$-VANOL as chiral ligand): 94\% ee (HPLC conditions: Chiralcel AD-H column, hexane $/ i-\mathrm{PrOH}=70 / 30,1.0 \mathrm{~mL} / \mathrm{min}, \lambda=280 \mathrm{~nm}, t_{R}$ (major) $=27.4 \mathrm{~min}, t_{R}$ (minor) $=23.5 \mathrm{~min}$ ). The endo-isomer 18 ( $R$-6, 6'-dibromo-VANOL as chiral ligand): 96\% ee (HPLC conditions: Chiralcel AD-H column, hexane $/ i-\mathrm{PrOH}=70 / 30,1.0 \mathrm{~mL} / \mathrm{min}, \lambda=280 \mathrm{~nm}, t_{R}$ (major) $=25.4 \mathrm{~min}, t_{R}($ minor $)=21.9 \mathrm{~min}$ ). 


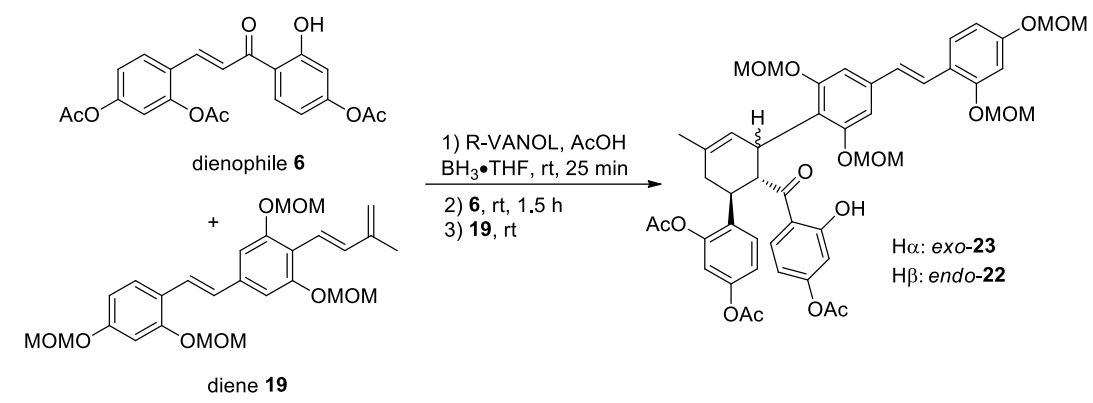

\section{Exo-23 and Endo-22}

To a solution of $R$-VANOL $(55.1 \mathrm{mg}, 0.126 \mathrm{mmol})$ in THF $(0.3 \mathrm{~mL})$ was added $\mathrm{BH}_{3} \cdot$ THF $(60.3 \mu \mathrm{L}$, $0.0603 \mathrm{mmol})$ and $\mathrm{AcOH}(3.5 \mu \mathrm{L}, 0.0603 \mathrm{mmol})$ sequentially. The resulting mixture was stirred at room temperature for $25 \mathrm{~min}$, and then concentrated to dryness and further dried under high vacuum at room temperature for $30 \mathrm{~min}$. The resulting solid was dissolved in dry THF $(0.5 \mathrm{~mL})$, and then pre-activated $5 \AA$ molecular sieve $(400 \mathrm{mg})$ and the dienophile $6(20 \mathrm{mg}, 0.0523 \mathrm{mmol})$ were added to the solution. The resulting solution was stirred at room temperature for $1.5 \mathrm{~h}$ before the diene 19 (26.9 $\mathrm{mg}, 0.0553$ mmol) was added to the reaction mixture. After $23 \mathrm{~h}$, the reaction mixture was quenched by addition of $\mathrm{H}_{2} \mathrm{O}(13.6 \mu \mathrm{L}, 15.0 \mathrm{eq})$ and filtered through a pad of celite. The celite was further washed with EtOAc, and the organic filtrates were collected and concentrated in vacuo. The crude product was filtrated through a pad of silica gel to get the mixture of exo-23 and endo-22 before determination of the ratio of endo/exo by NMR (endo/exo = 1:1.2). Further purification was achieved by flash column chromatography (petroleum ether/EtOAc $=5: 1$ to $1: 1$ ) to afford the exo-23 as light yellow solid in a yield of $20.5 \mathrm{mg}(0.0232 \mathrm{mmol}, 47 \%)$ and endo-22 as light yellow solid in a yield of $18.7 \mathrm{mg}(0.0211$ $\mathrm{mmol}, 42 \%)$.

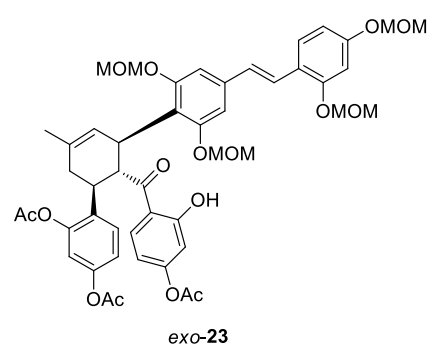

\section{Exo-23}

Mp: 51-53 ${ }^{\circ} \mathrm{C} ;[\alpha]^{22} \mathrm{D}+260(\mathrm{c} 0.18 \mathrm{MeOH}) ;{ }^{1} \mathrm{H}$ NMR $\left(400 \mathrm{MHz}, \mathrm{CDCl}_{3}\right) \delta 12.44(\mathrm{~s}, 1 \mathrm{H}), 7.45(\mathrm{~d}, J=$ $8.8 \mathrm{~Hz}, 1 \mathrm{H}), 7.34(\mathrm{~d}, J=8.8 \mathrm{~Hz}, 1 \mathrm{H}), 7.22(\mathrm{~d}, J=14.0 \mathrm{~Hz}, 1 \mathrm{H}), 7.18(\mathrm{~d}, J=6.8 \mathrm{~Hz}, 1 \mathrm{H}), 6.84-6.80(\mathrm{~m}$, $5 \mathrm{H}), 6.70(\mathrm{dd}, J=2.4,8.8 \mathrm{~Hz}, 1 \mathrm{H}), 6.67(\mathrm{~s}, 1 \mathrm{H}), 6.44(\mathrm{~d}, J=2.4 \mathrm{~Hz}, 1 \mathrm{H}), 6.27(\mathrm{dd}, J=2.4,8.8 \mathrm{~Hz}, 1 \mathrm{H})$, $5.35(\mathrm{~s}, 1 \mathrm{H}), 5.30(\mathrm{~d}, J=6.0 \mathrm{~Hz}, 1 \mathrm{H}), 5.24(\mathrm{~d}, J=7.2 \mathrm{~Hz}, 1 \mathrm{H}), 5.22(\mathrm{~s}, 2 \mathrm{H}), 5.17(\mathrm{~s}, 2 \mathrm{H}), 4.96(\mathrm{~d}, J=6.0$ $\mathrm{Hz}, 1 \mathrm{H}), 4.87(\mathrm{~d}, J=6.4 \mathrm{~Hz}, 1 \mathrm{H}), 4.54(\mathrm{~d}, J=10.0 \mathrm{~Hz}, 1 \mathrm{H}), 4.47(\mathrm{~s}, 1 \mathrm{H}), 3.78(\mathrm{~d}, J=6.8 \mathrm{~Hz}, 1 \mathrm{H}), 3.61$ (s, 3H), 3.52 (s, 3H), 3.48 (s, 3H), 3.37 (s, 3H), 2.43 (s, 3H), 2.26 (d, $J=4.4 \mathrm{~Hz}, 2 \mathrm{H}), 2.20$ (s, 3H), 2.17(s, 3H), $1.74(\mathrm{~s}, 3 \mathrm{H}) ;{ }^{13} \mathrm{C}$ NMR $\left(100 \mathrm{MHz}, \mathrm{CDCl}_{3}\right) \delta 208.8,169.2,168.9,168.2,163.5,158.0,156.7$, 156.1, 155.8, 155.7, 149.0, 148.6, 138.7, 131.4, 131.1, 127.6, 127.3, 124.6, 123.4, 121.3, 119.3, 118.6, 116.4, 111.8, 110.2, 109.6, 106.5, 104.1, 95.2, 94.9, 94.6, 56.5, 56.4, 56.2, 56.0, 48.1, 38.3, 23.2, 21.3, 21.2, 21.1, 19.2; IR (neat): $v_{\max }\left(\mathrm{cm}^{-1}\right) 1767,1632,1599,1500,1194,1151,1042,1013,923$; HRMS (ESI) $[\mathrm{M}+\mathrm{H}]{ }^{+}$calculated for $\mathrm{C}_{48} \mathrm{H}_{52} \mathrm{O}_{16}: 885.3328$, found: 885.3310. The exo-23 ( $R$-VANOL as chiral ligand): $-76 \%$ ee (HPLC conditions: Chiralcel AD-H column, hexane $/ i-\mathrm{PrOH}=72 / 28,1.0 \mathrm{~mL} / \mathrm{min}, \lambda=$ $280 \mathrm{~nm}, t_{R}($ major $)=6.5 \mathrm{~min}, t_{R}($ minor $\left.)=8.5 \mathrm{~min}\right)$. 


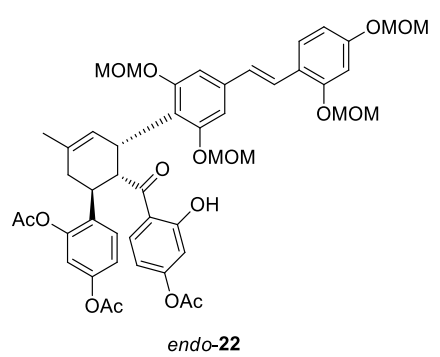

\section{Endo-22}

Mp: 53-55 ${ }^{\circ} \mathrm{C} ;[\alpha]^{26} \mathrm{D}+215(\mathrm{c} 0.095 \mathrm{MeOH}) ;{ }^{1} \mathrm{H}$ NMR $\left(400 \mathrm{MHz}, \mathrm{CDCl}_{3}\right) \delta 12.26,7.67(\mathrm{~d}, J=8.8 \mathrm{~Hz}$, $1 \mathrm{H}), 7.45(\mathrm{~d}, J=8.8 \mathrm{~Hz}, 1 \mathrm{H}), 7.25(\mathrm{~d}, J=4.4 \mathrm{~Hz}, 1 \mathrm{H}), 7.22(\mathrm{~d}, J=3.6 \mathrm{~Hz}, 1 \mathrm{H}), 6.89$ (dd, $J=2.4,8.4 \mathrm{~Hz}$, $1 \mathrm{H}), 6.86-6.81(\mathrm{~m}, 3 \mathrm{H}), 6.75(\mathrm{~s}, 2 \mathrm{H}), 6.70(\mathrm{dd}, J=2.4,8.4 \mathrm{~Hz}, 1 \mathrm{H}), 6.54(\mathrm{~d}, J=2.4 \mathrm{~Hz}, 1 \mathrm{H}), 6.49$ (dd, $J=$ 2.0, $8.8 \mathrm{~Hz}, 1 \mathrm{H}$ ), 5.52 (d, $J=2.8 \mathrm{~Hz}, 1 \mathrm{H}$ ), 5.22 (s, 2H), 5.17 (s, 2H), 4.86 (br.s, $2 \mathrm{H}$ ), 4.54 (br.s, $1 \mathrm{H}$ ), 4.16 (dd, $J=6.4,8.8 \mathrm{~Hz}, 1 \mathrm{H}$ ), 4.08 (dd, $J=7.6,14.8 \mathrm{~Hz}, 1 \mathrm{H}$ ), 3.51 (s, 3H), 3.49 (s, 3H), 3.33 (br.s, 6H), 2.54 $(\mathrm{dd}, J=6.4,18.4 \mathrm{~Hz}, 1 \mathrm{H}), 2.25$ (s, 3H), $2.24(\mathrm{~s}, 6 \mathrm{H}), 2.18(\mathrm{~d}, J=7.6 \mathrm{~Hz}, 1 \mathrm{H}), 1.82(\mathrm{~s}, 3 \mathrm{H}) ;{ }^{13} \mathrm{C}$ NMR $\left(100 \mathrm{MHz}, \mathrm{CDCl}_{3}\right) \delta 206.2,169.2,169.1,168.5,163.6,157.9,155.9,155.7,148.9,148.7,138.8,135.1$, 132.3, 131.0, 127.8, 127.7, 127.4, 123.5, 122.5, 121.4, 119.3, 118.7, 117.5, 116.3, 112.2, 110.8, 109.6, 104.0, 95.1, 94.7, 94.6, 56.4, 56.2, 56.0, 49.5, 36.7, 34.6, 31.9, 23.5, 21.2, 21.1; IR (neat): $v_{\max }\left(\mathrm{cm}^{-1}\right)$ 1766, 1598, 1501, 1196, 1152, 1042, 1012, 921; HRMS (ESI) $[\mathrm{M}+\mathrm{H}]+$ calculated for $\mathrm{C}_{48} \mathrm{H}_{52} \mathrm{O}_{16}$ : 885.3328, found: 885.3320. The endo-22 ( $R$-VANOL as chiral ligand): 90\% ee (HPLC conditions: Chiralcel AD-H column, hexane $/ i-\mathrm{PrOH}=82 / 18,1.0 \mathrm{~mL} / \mathrm{min}, \lambda=280 \mathrm{~nm}, t_{R}$ (major) $=19.0 \mathrm{~min}, t_{R}$ (minor) $=15.5 \mathrm{~min})$. 
Data File D: \DATA \GL \GL-06-56-RAC014.D

Sample Name: GL-06-56-Rac-endo-1

Acq. Operator : gl

Acq. Instrument : 仪器 1

Injection Date : 6/19/2015 11:40:55 AM

Acq. Method : D: \METHODS $\backslash 70$ HEX.M

Last changed : 6/19/2015 12:11:35 PM by gl (modified after loading)

Analysis Method : D: \METHODS \90HEX.M

Last changed : 8/6/2015 11:06:14 PM by gl (modified after loading)
Location : Vial 1

Inj Volume : $15 \mu \mathrm{l}$

\section{Endo-product 18 racemic}

Sample Info: : gl-06-56-Rac-endo 70 hex AD

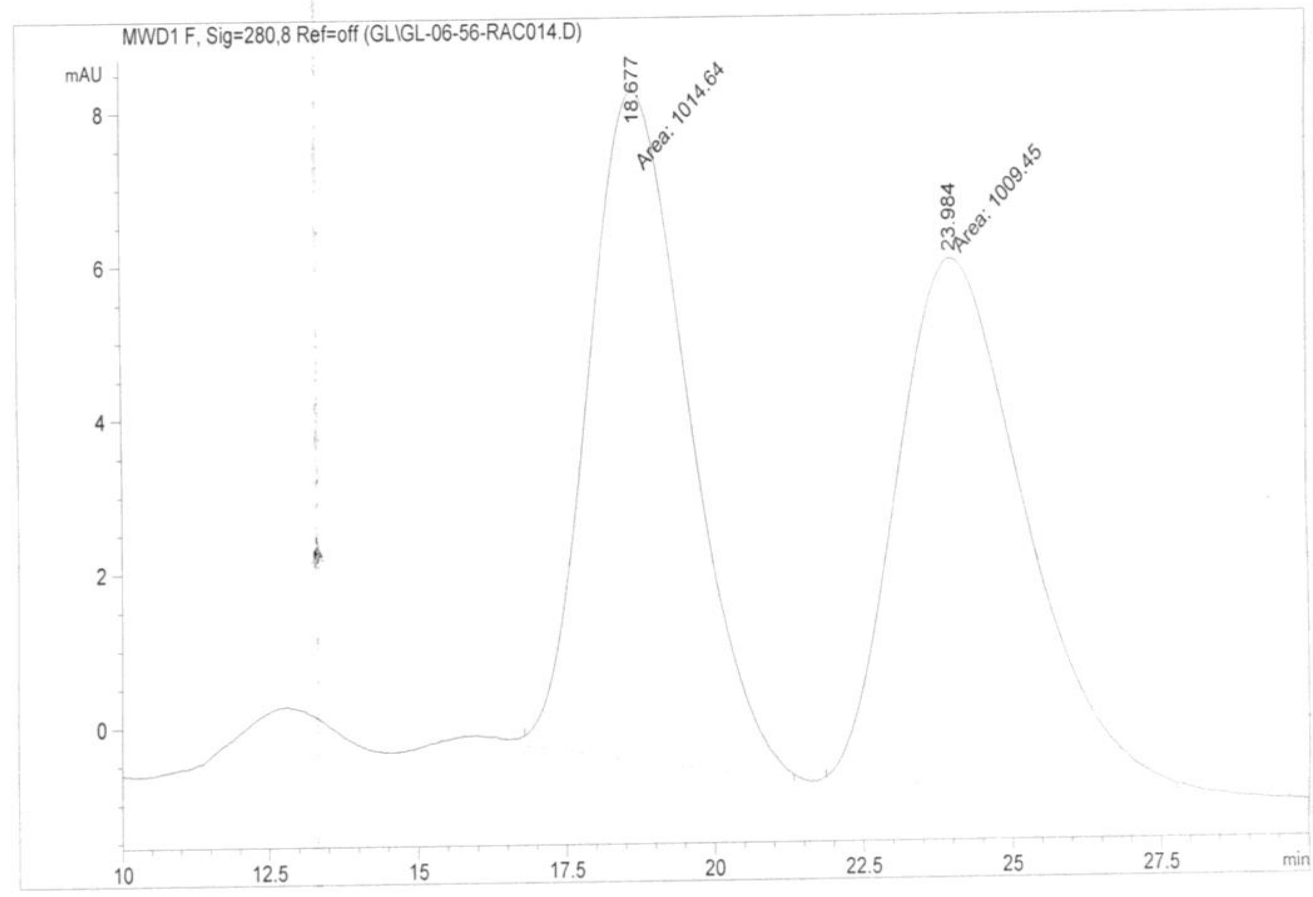

Area Percent Report

\begin{tabular}{l|cc} 
Sorted By & $:$ & Signal \\
Multiplier: & $:$ & 1.0000 \\
Dilution: & $:$ & 1.0000 \\
Use Multiplier \& Dilution Factor with & ISTDs
\end{tabular}

Use Multiplier \& Dilution Factor with ISTDS

Signal 1: MWD1 E, Sig=280,8 Ref=off

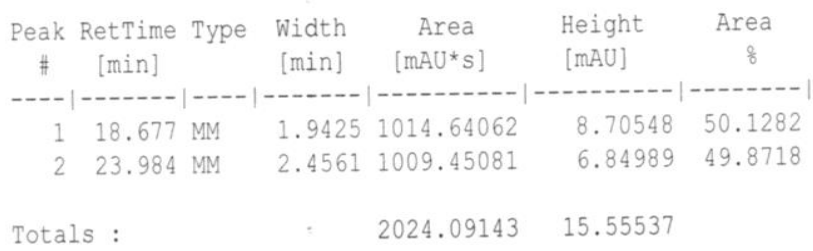

$\star \star \star$ End of Report $\star * \star *$ 
Data File D: \DATA \GL \GL-06-67-ENDO30.D

Sample Name: GL-06-67-endo-1

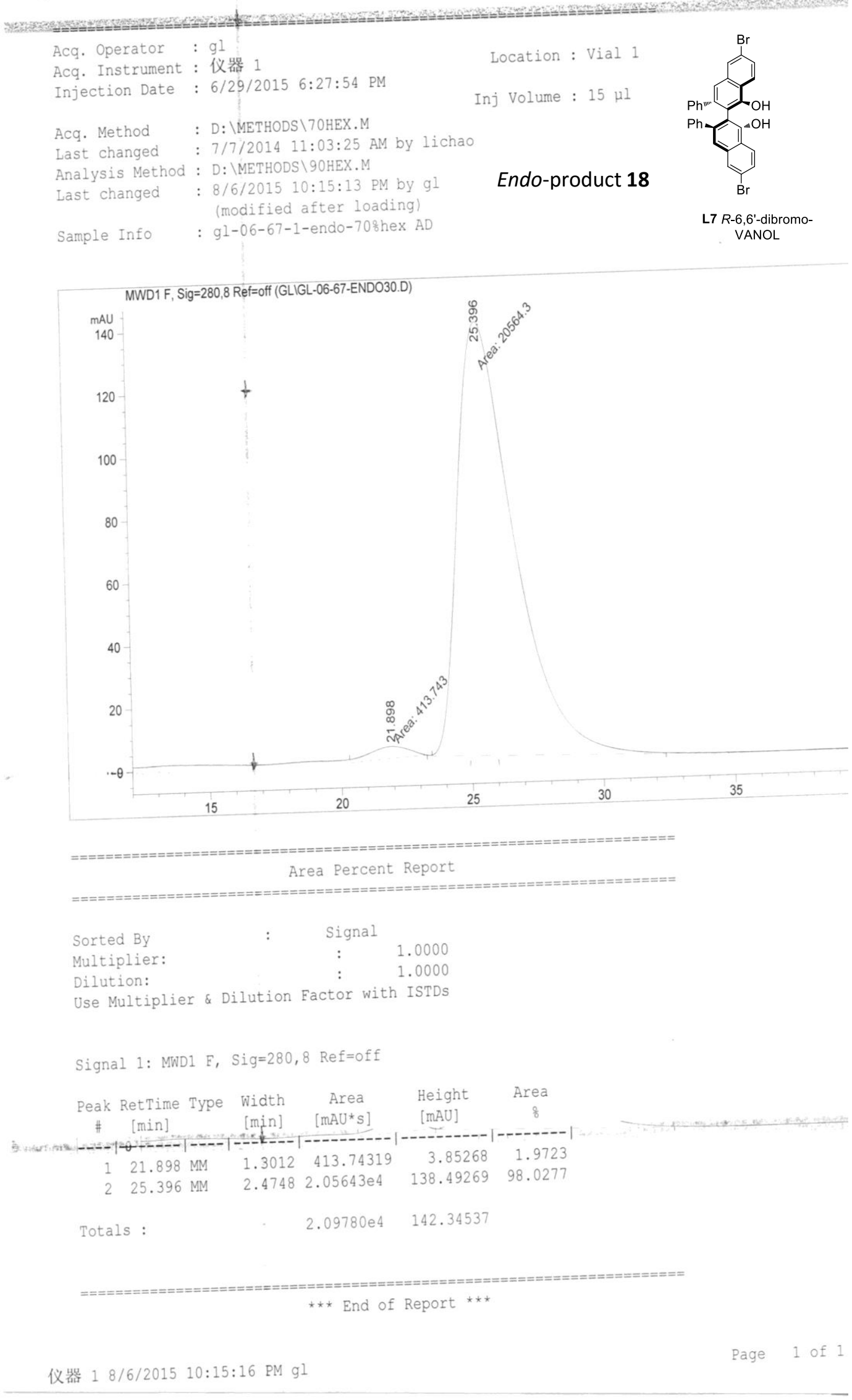


Data Eile D: \DATA \GL \GL-06-71-ENDO34.D

$========= \pm=========$
Acq. Operator : gl

Acq. Instrument : 仪器 1

Injection Date : 7/4/2015 10:52:51 PM

Acq. Method : D: \METHODS $\backslash 50$ HEX.M

Last changed : 7/4/2015 10:42:20 PM by gI (modified after loading)

Analysis Method : D: \METHODS $\backslash 90$ HEX.M

Last changed : 8/6/2015 10:25:58 PM by gl (modified after loading)

Sample Info : gl-06-71-endo-1-70\%hex AD
Location : Vial 1

Inj Volume : $20 \mu \mathrm{l}$

\section{Endo-product 18}

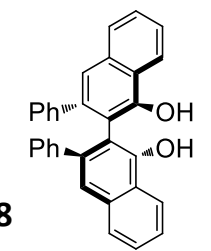

R-VANOL

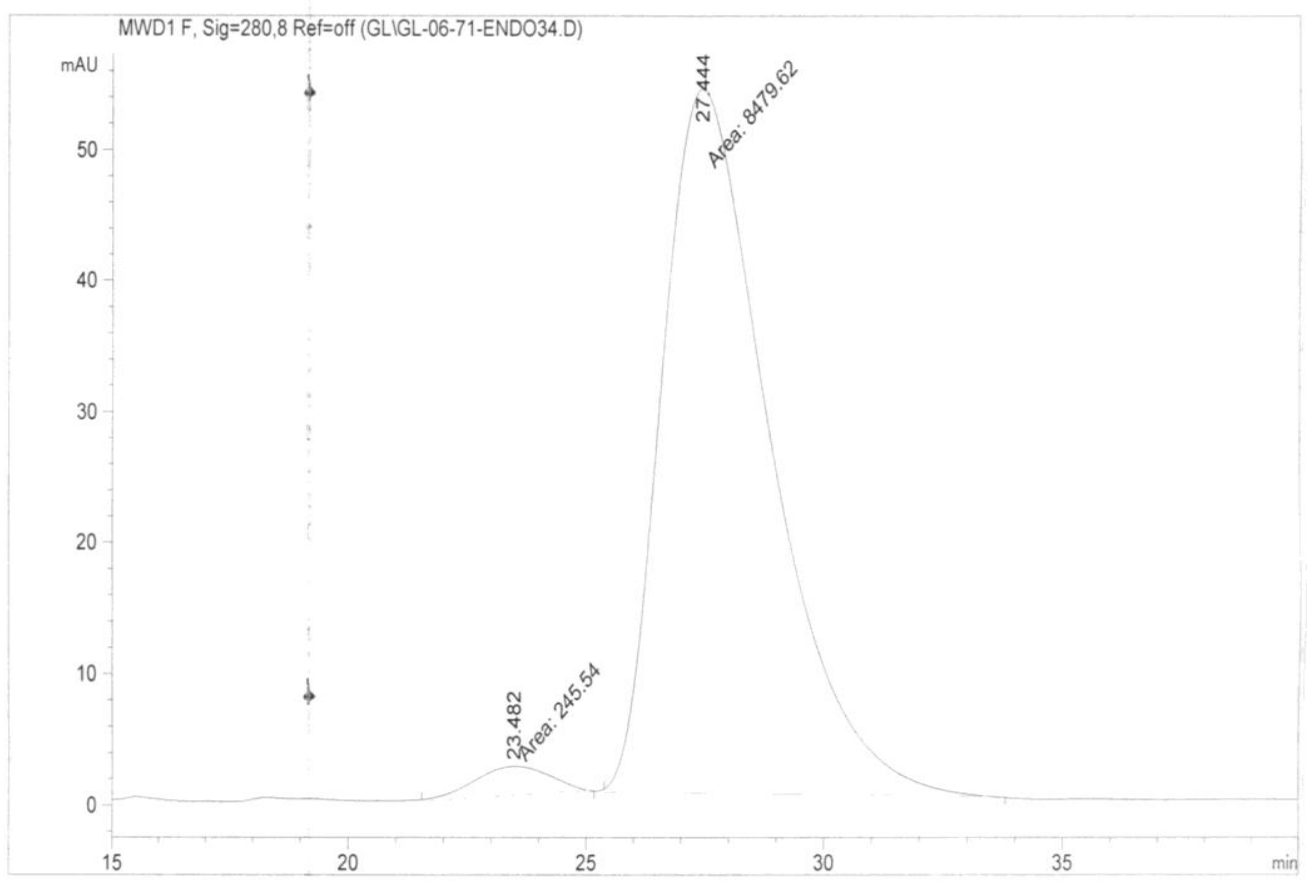

Area Percent Report

$\begin{array}{lccc}\text { Sorted By } & : & \text { Signal } & \\ \text { Multiplier: } & : & 1.0000 \\ \text { Dilution: } & & : & 1.0000\end{array}$

Dilution:

1.0000

Use Multiplier \& Dilution Factor with ISTDs

Signal 1: MWD1 F, $\operatorname{Sig}=280,8$ Ref=off

\begin{tabular}{|c|c|c|c|c|c|}
\hline $\begin{array}{c}\text { Peak } \\
\quad \#\end{array}$ & $\begin{array}{l}\text { RetTime Type } \\
\text { [min] }\end{array}$ & $\begin{array}{l}\text { Width } \\
\text { [min] }\end{array}$ & $\begin{array}{c}\text { Area } \\
{\left[\mathrm{mAU}{ }^{*} \mathrm{~s}\right]}\end{array}$ & $\begin{array}{l}\text { Height } \\
\text { [mAU] }\end{array}$ & $\begin{array}{c}\text { Area } \\
\quad \%\end{array}$ \\
\hline & & & 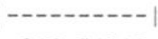 & - & $-\infty-\infty$ \\
\hline 1 & $23.482 \mathrm{MM}$ & 1.8483 & 245.54012 & 2.21408 & 2.8142 \\
\hline 2 & $27.444 \mathrm{MM}$ & 2.6305 & 8479.61816 & 53.72617 & 97.1858 \\
\hline
\end{tabular}

Totals : $\quad 8725.15828 \quad 55.94025$

\section{$* * *$ End of Report $* * *$}


Data File D: \DATA \GL \GL-06-56-RAC010.D

Sample Name: GL-06-56-rac-exo-3

Acq. Operator : gl

Acq. Instrument : 仪器 1

Injection Date : 6/18/2015 9:41:57 PM

Acq. Method : D: \METHODS \90HEX.M

Last changed : 6/18/2015 10:11:52 PM by gl (modified after loading)

Analysis Method : D: \METHODS \90HEX.M

Last changed : 8/6/2015 10:48:33 PM by gl (modified after loading)

Sample Info : gl-06-56-Rac-exo60\%hex AD

Location : Vial 1

Inj Volume : $10 \mu 1$

Exo-product 17 racemic

$\mathrm{mAU}$

50

40

30

20

10

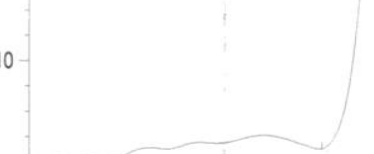

0

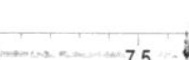

10

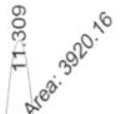

$\begin{array}{lccc}\text { Sorted By } & : & \text { Signal } & \\ \text { Multiplier: } & & : & 1.0000 \\ \text { Dilution: } & & : & 1.0000\end{array}$

Use Multiplier \& Dilution Factor with ISTDs

Signal 1: MWD1 F, Sig=280,8 Ref=off

\begin{tabular}{|c|c|c|c|c|c|}
\hline $\begin{array}{c}\text { Peak } \\
\quad \#\end{array}$ & $\begin{array}{l}\text { RetTime Type } \\
\text { [min] }\end{array}$ & $\begin{array}{l}\text { Width } \\
\text { [min] }\end{array}$ & $\begin{array}{c}\text { Area } \\
{\left[m A U^{\star} s\right]}\end{array}$ & $\begin{array}{l}\text { Height } \\
\text { [mAU] }\end{array}$ & $\begin{array}{c}\text { Area } \\
\quad \frac{8}{8}\end{array}$ \\
\hline$=-$ & -1 & $-\cdots$ & 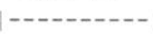 & - & ------ \\
\hline 1 & $11.309 \mathrm{MM}$ & 1.2023 & 3920.16235 & 54.34370 & 49.6732 \\
\hline 2 & $17.924 \mathrm{MM}$ & 2.4613 & 3971.74194 & 26.89477 & 50.3268 \\
\hline Tota & & & 7891.90430 & 3847 & \\
\hline
\end{tabular}

$\star \star \star$ End of Report $\star \star \star \star$

仪器 $18 / 6 / 2015$ 10:48:35 PM gl 
Data File D:\DATA \GL\GL-06-59-R00011.D

Sample Name: GL-06-59-R-exo-

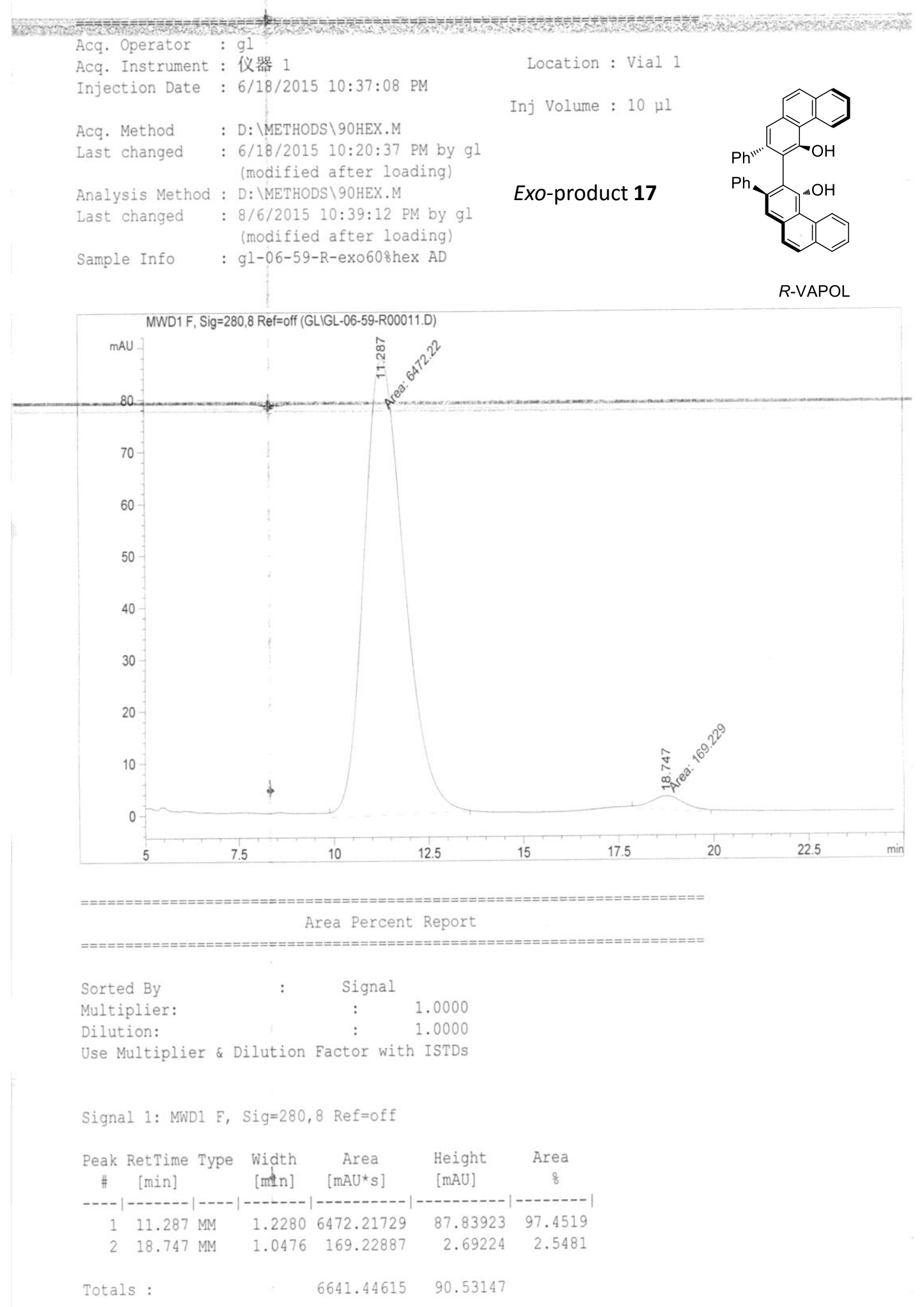

$\star * \star$ End of Report $\star \star \star *$ 
Data File D: \DATA \GL\GL-06-66-EX0028.D

Sample Name: GL-06-66-exo

Acq. Operator : gl

Acq. Instrument : 仪器 1

Injection Date : 6/28/2015 3:24:51 PM

Location : Vial 1

Acq. Method : D: \METHODS \50HEX.M

Last changed : 6/28/2015 $3: 22: 40$ PM by gl (modified after loading)

Analysis Method : D: \METHODS \90HEX.M

Last changed : 8/6/2015 10:31:56 PM by gl

(modified after loading)

Sample Info : gl-06-66-exo-60\%hex AD

Inj Volume : $20 \mu 1$

\section{Exo-product 17}

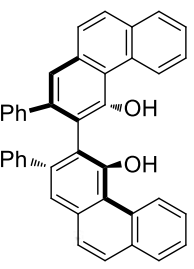

S-VAPOL

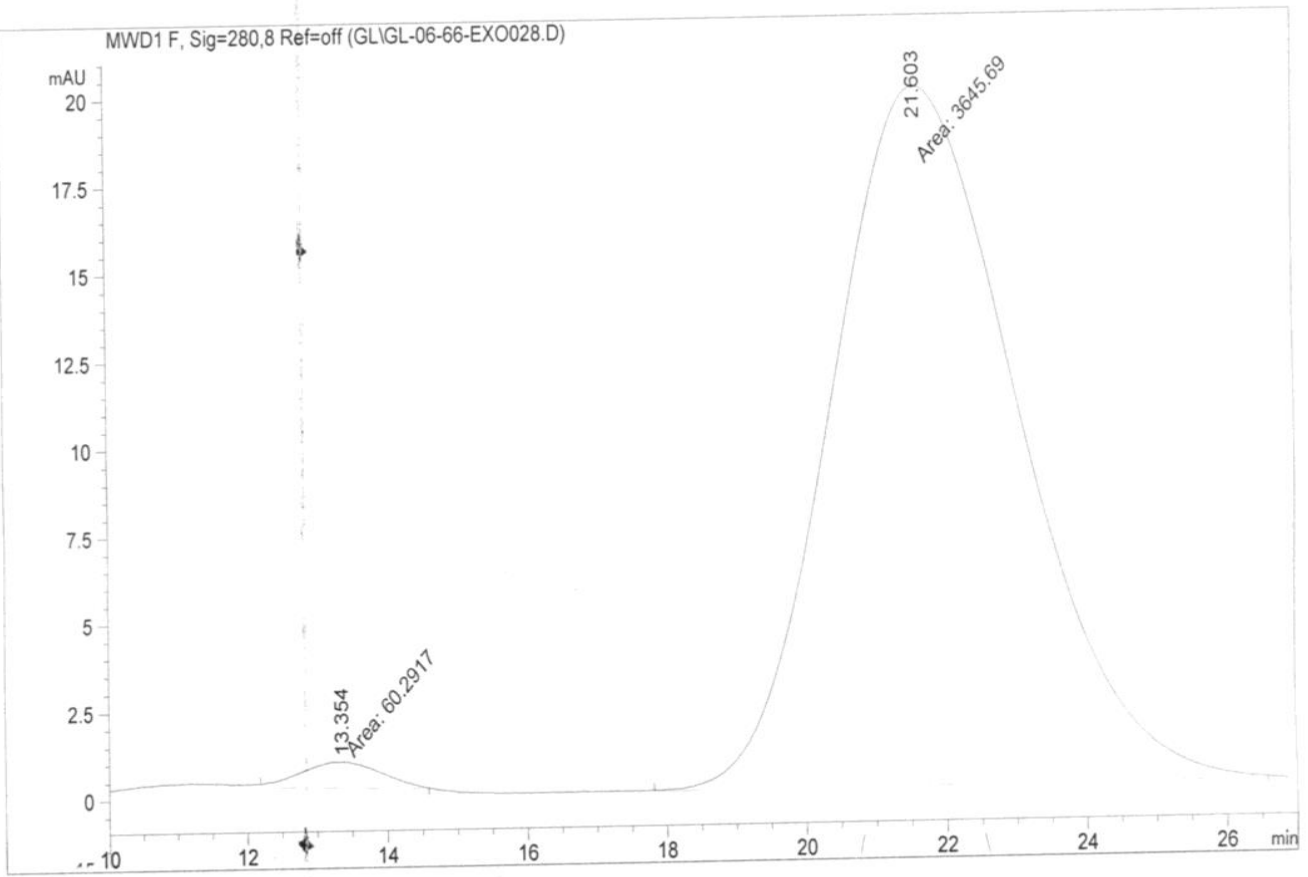

Area Percent Report

Sorted By

Multiplier:

Signal

Dilution:

1.0000

$: \quad 1.0000$

Use Multiplier \& Dilution Factor with ISTDS

Signal 1: NWD1 F, Sig=280,8 Ref=off

\begin{tabular}{|c|c|c|c|c|c|c|}
\hline $\begin{array}{c}\text { Peak } \\
\#\end{array}$ & $\begin{array}{c}\text { RetTime } \\
\text { [min] }\end{array}$ & Type & $\begin{array}{l}\text { Width } \\
\text { [min] }\end{array}$ & $\begin{array}{c}\text { Area } \\
{\left[\mathrm{mAU}{ }^{*} \mathrm{~S}\right]}\end{array}$ & $\begin{array}{l}\text { Height } \\
{[\mathrm{mAU}]}\end{array}$ & $\begin{array}{c}\text { Area } \\
\frac{\circ}{6}\end{array}$ \\
\hline 1 & 13.354 & MM & 1.3363 & 60.29174 & $7.51987 \mathrm{e}-1$ & 1.6269 \\
\hline 2 & 21.603 & MM & 3.8397 & 3645.69482 & 19.98943 & 98.3731 \\
\hline Tota & Is : & & & 3705.98656 & 20.74141 & \\
\hline
\end{tabular}

*** End of Report *** 
Data File D: \DATA \GL \GL-07-09000056.D

Sample Name: gl-07-09-rac-endo-1

Acq. Operator : gl

Acq. Instrument : 仪器 1

Injection Date : 8/3/2015 8:11:14 PM

Acq. Method : D: $\backslash$ METHODS $\backslash 70$ HEX.M

Last changed : 8/3/2015 8:09:06 PM by gl

(modified after loading)

Analysis Method : D: \METHODS $\backslash 90$ HEX.M

Last changed : 8/19/2015 4:36:59 PM by gl

(modified after loading)
Location : Vial 1

Inj Volume : $10 \mu l$

Endo-product 22 racemic

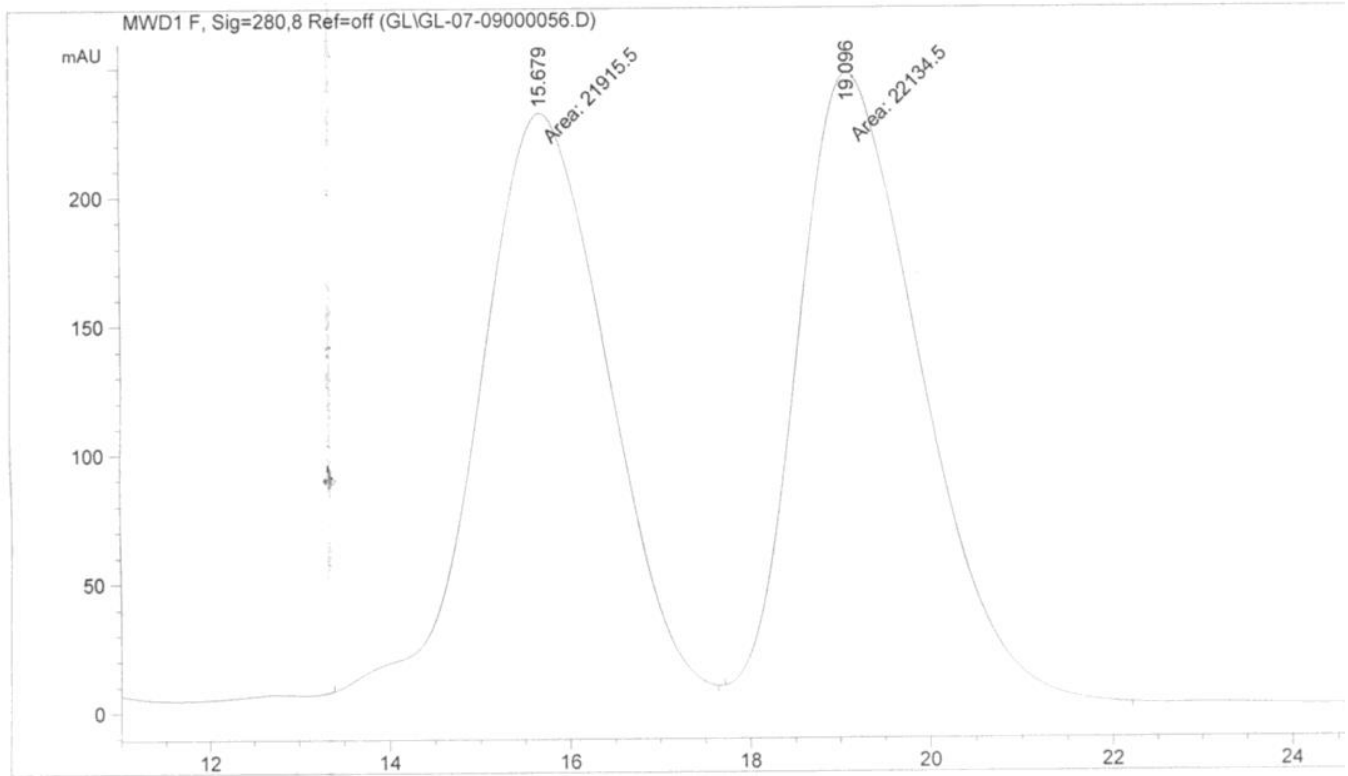

Area Percent Report

Sorted By : : Signal

Multiplier: $\quad: \quad 1.0000$

Dilution: $\quad$ : 1.0000

Use Multiplier \& Dilution Factor with ISTDS

Signal 1: MWD1 F, Sig=280,8 Ref=off

\begin{tabular}{|c|c|c|c|c|c|c|}
\hline $\begin{array}{c}\text { Peak } \\
\#\end{array}$ & $\begin{array}{c}\text { RetTime } \\
\text { [min] }\end{array}$ & Type & $\begin{array}{l}\text { Width } \\
\text { [min] }\end{array}$ & $\begin{array}{c}\text { Area } \\
{\left[\mathrm{mAU}^{\star} \mathrm{s}\right]}\end{array}$ & $\begin{array}{l}\text { Height } \\
\text { [mAU] }\end{array}$ & $\begin{array}{c}\text { Area } \\
\text { \& }\end{array}$ \\
\hline 1 & 15.679 & MM & & $2.19155 \mathrm{e} 4$ & 225.69235 & 49.7514 \\
\hline 2 & 19.096 & MM & 1.5339 & $2.21345 \mathrm{e} 4$ & 240.49763 & 50.2486 \\
\hline ta & & & & $4.40501 \mathrm{e} 4$ & . 18999 & \\
\hline
\end{tabular}

$\star \star \star$ End of Report $\star \star \star$ 
Data File D: \DATA \GL \GL-07-28000065.D

Sample Name: gl-07-28-endo

Acq. Operator : gl

Acq. Instrument : 仪器 1

Injection Date : 8/24/2015 3:43:03 PM

Acq. Method : D: \METHODS $\backslash 90$ HEX.M

Last changed : 8/24/2015 3:41:02 PM by gl (modified after loading)

Analysis Method : D: \METHODS \90HEX.M

Last changed : 9/1/2015 10:54:37 PM by gl (modified after loading)

Sample Info : gl-07-28-endo-828-AD

Location : Vial 1

Inj Volume : $20 \mu l$

Endo-product 22

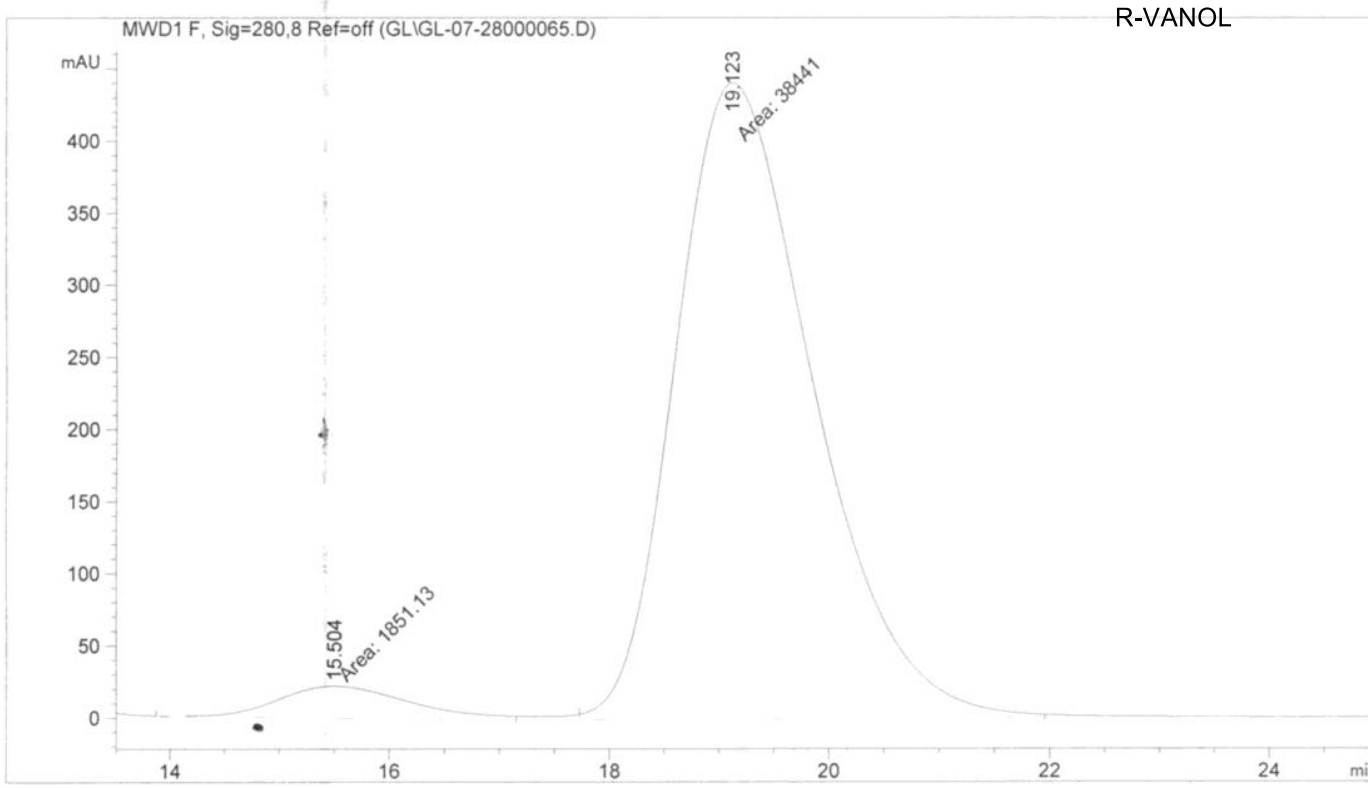

Area Percent Report

$\begin{array}{llcl}\text { Sorted By } & \text { t } & \text { Signal } & \\ \text { Multiplier: } & : & 1.0000 \\ \text { Dilution: } & & : & 1.0000\end{array}$

Use Multiplier \& Dilution Factor with ISTDs

Signal 1: MWD1 F, $\operatorname{Sig}=280,8$ Ref $=0 f f$

\begin{tabular}{|c|c|c|c|c|c|c|}
\hline $\begin{array}{c}\text { Peak } \\
\#\end{array}$ & $\begin{array}{c}\text { RetTime } \\
\text { [min] }\end{array}$ & Type & $\begin{array}{l}\text { Width } \\
\text { [min] }\end{array}$ & $\begin{array}{c}\text { Area } \\
{\left[\mathrm{mAU} \mathbf{U}^{*} \mathrm{~s}\right]}\end{array}$ & $\begin{array}{l}\text { Height } \\
\text { [mAU] }\end{array}$ & $\begin{array}{c}\text { Area } \\
8\end{array}$ \\
\hline 1 & 15.504 & MM & 1.3867 & 1851.13086 & 22.24936 & 4.5943 \\
\hline 2 & 19.123 & MM & 1.4516 & $3.84410 e 4$ & 441.36026 & 95.4057 \\
\hline
\end{tabular}

Totals:

$4.02921 \mathrm{e} 4 \quad 463.60962$

1. $\star \star \star$ End of Report $\star \star \star$ 
Data File D: \DATA \GL \GL-07-09000059.D

Sample Name: gl-07-09-exo

Acq. Operator : gl

Acq, Instrument : 仪器 1

Location : Vial

Injection Date : 8/3/2015 11:26:54 PM

Inj Volume : $20 \mu l$

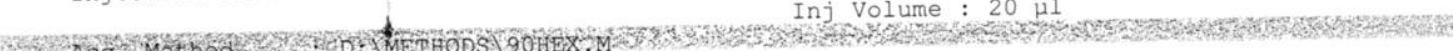
Last changed : 8/3/2015 11:39:33 PM by $\mathrm{gl}$ (modified after loading)

Analysis Method : D: \METHODS $\backslash 90$ HEX.M

Last changed : 9/1/2015 10:57:29 PM by gl exo-product 23 racemic

Sample Info: gl-07-09-rac-exo-72\%-AD

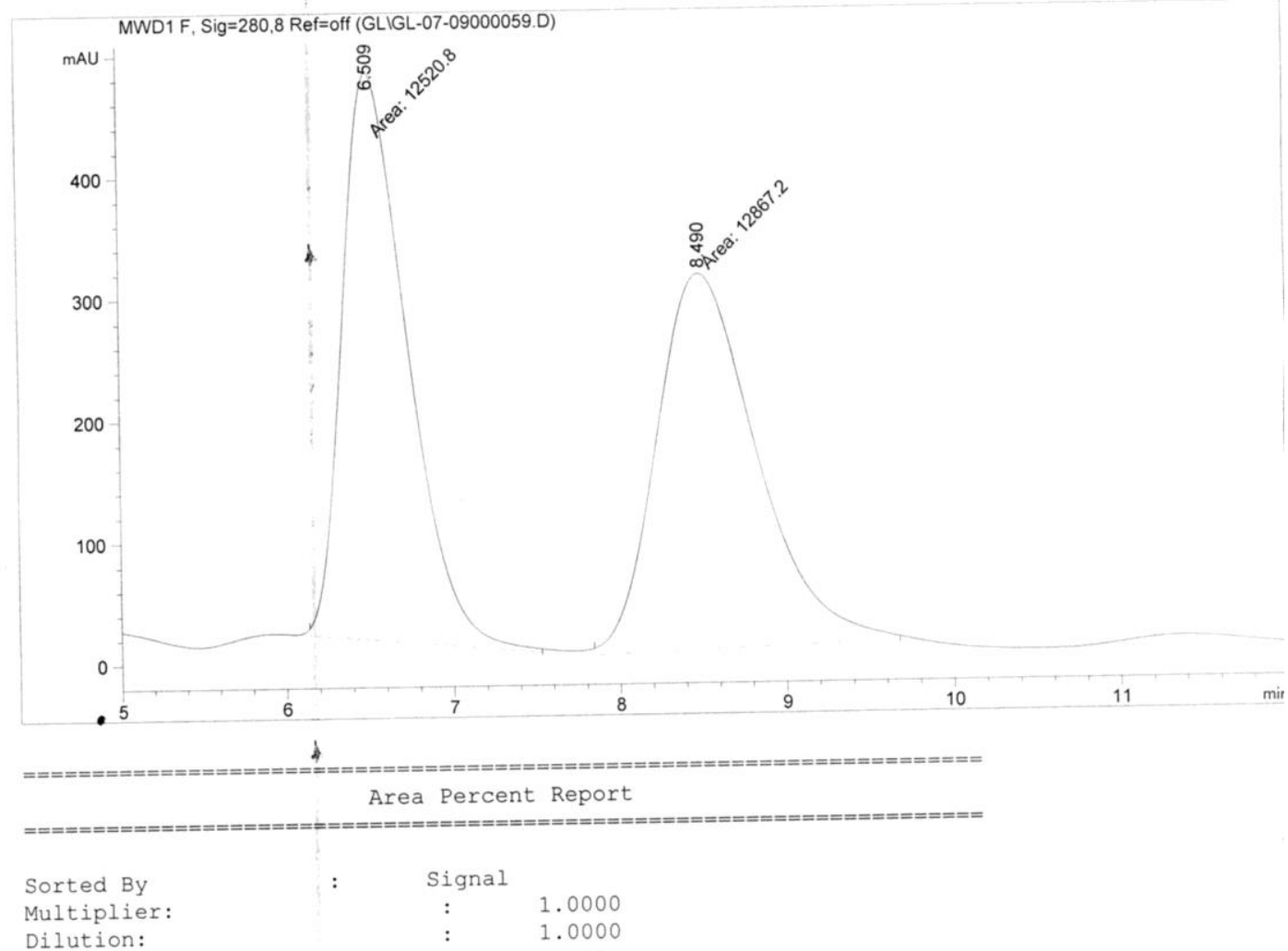

Dilution:

$: \quad 1.0000$

Use Multiplier \& Dilution Factor with ISTDS

Signal 1: MWD1 F, Sig=280,8 Ref=off

\begin{tabular}{|c|c|c|c|c|c|c|}
\hline $\begin{array}{c}\text { Peak } \\
\# \\
--1\end{array}$ & $\begin{array}{l}\text { RetTime } \\
\text { [min] }\end{array}$ & Type & $\begin{array}{l}\text { Width } \\
\text { [min] }\end{array}$ & $\begin{array}{c}\text { Area } \\
{\left[\mathrm{mAU}{ }^{\star} \mathrm{s}\right]}\end{array}$ & $\begin{array}{l}\text { Height } \\
\text { [mAU] }\end{array}$ & $\begin{array}{c}\text { Area } \\
\frac{8}{8}\end{array}$ \\
\hline--1 & ------1 & $|----|$ & -----1 & -------- & ---1 & ----1 \\
\hline $\begin{array}{l}1 \\
2\end{array}$ & $\begin{array}{l}6.509 \\
8.490\end{array}$ & $\begin{array}{l}\text { MM } \\
\text { MM }\end{array}$ & $\begin{array}{l}0.4479 \\
0.6943\end{array}$ & $\begin{array}{l}1.25208 \mathrm{e} 4 \\
1.28672 \mathrm{e} 4\end{array}$ & $\begin{array}{l}465.86890 \\
308.87372\end{array}$ & $\begin{array}{l}49.3178 \\
50.6822\end{array}$ \\
\hline Total & Is : & & $\$$ & $2.53879 \mathrm{e} 4$ & 774.74261 & \\
\hline
\end{tabular}

$\star \star \star$ End of Report $\star * \star$ 
Data File D: \DATA \GL \GL-07-08000060.D

Sample Name: gl-07-08-exo

Acq. Operator : gl

Acq. Instrument : 仪器 1

Injection Date : 8/4/2015 12:05:33 AM

Location : Vial

Acq. Method : D: \METHODS $\backslash 90$ HEX.M

Last changed : 8/4/2015 12:18:01 AM by gl

(modified after loading)

Analysis Method : D: \METHODS $\backslash 90$ HEX.M

Last changed : 9/1/2015 10:57:29 PM by gl

(modified after loading)

Inj Volume : $20 \mu 1$

$$
\text { (modified after loading) }
$$

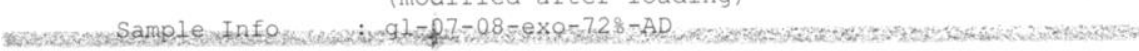

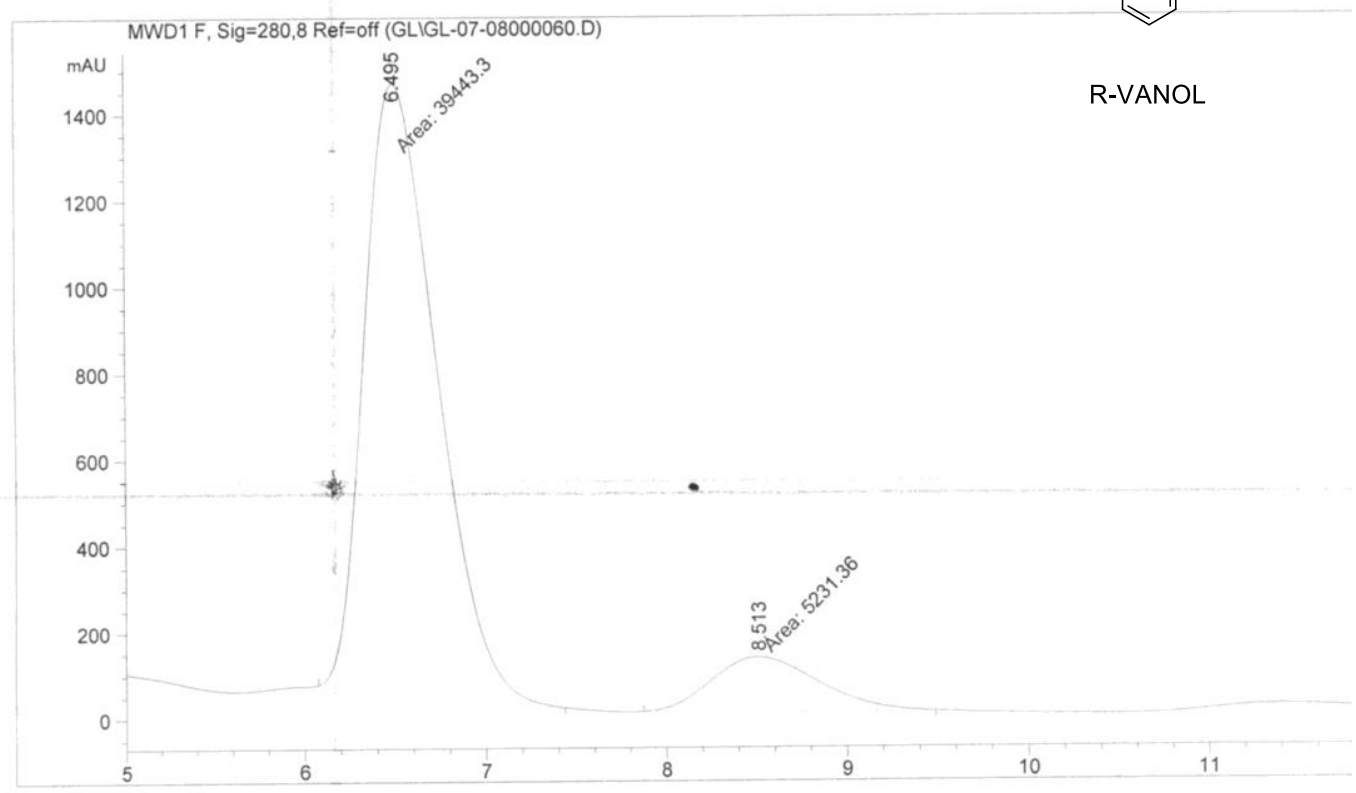

Area Percent Report

Sorted By

Signal

Multiplier:

Difution: $\quad$ o $\quad 1.0000$

Use Multiplier \& Dilution Factor with ISTDS

Signal 1: MWD1 E, Sig=280,8 Ref=off

\begin{tabular}{|c|c|c|c|c|c|c|}
\hline $\begin{array}{c}\text { Peak } \\
\quad \#\end{array}$ & $\begin{array}{l}\text { RetTime } \\
\text { [min] }\end{array}$ & Type & $\begin{array}{l}\text { Width } \\
\text { [min] }\end{array}$ & $\begin{array}{c}\text { Area } \\
{[\mathrm{mAU} * \mathrm{~s}]}\end{array}$ & $\begin{array}{l}\text { Height } \\
\text { [mAU] }\end{array}$ & $\begin{array}{c}\text { Area } \\
\frac{8}{8}\end{array}$ \\
\hline 1 & 6.495 & MM & 0.4631 & $3.94433 \mathrm{e} 4$ & 1419.59570 & 88.2901 \\
\hline 2 & 8.513 & MM & 0.6947 & 5231.35840 & 125.50135 & 11.7099 \\
\hline Tota. & : & & & $4.46747 \mathrm{e} 4$ & 1545.09705 & \\
\hline
\end{tabular}

$\star \star \star$ End of Report $\star \star \star$ 


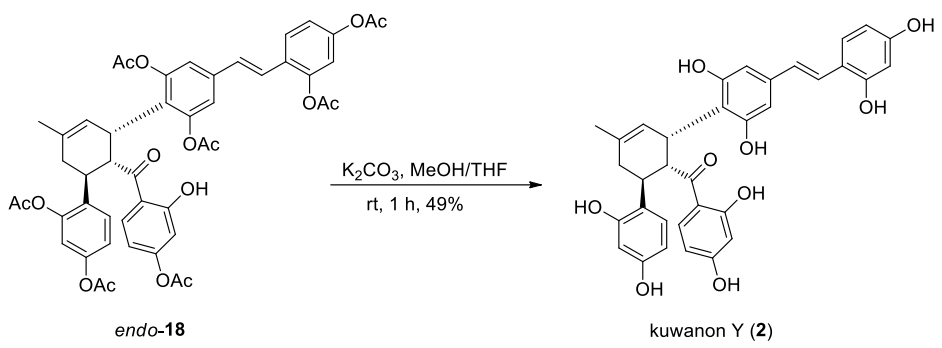

\section{Kuwanon Y (2)}

To a solution of endo-18 $(42.2 \mathrm{mg}, 0.0482 \mathrm{mmol})$ in THF $(0.6 \mathrm{~mL})$ and $\mathrm{MeOH}(1.2 \mathrm{~mL})$ was added $\mathrm{K}_{2} \mathrm{CO}_{3}(66.5 \mathrm{mg}, 0.482 \mathrm{mmol})$ at room temperature. The reaction was quenched by $10 \% \mathrm{HCOOH}$ aqueous solution after $1 \mathrm{~h}$, and the resulting mixture was extracted with EtOAc. The combined organic layers were washed by saturated $\mathrm{NaHCO}_{3}$ solution, followed by brine, dried over $\mathrm{Na}_{2} \mathrm{SO}_{4}$, and concentrated in vacuo. After purification by flash column chromatography $\left(\mathrm{CH}_{2} \mathrm{Cl}_{2} / \mathrm{MeOH}=95: 5\right)$, kuwanon Y (2) was obtained as an amorphous solid in a yield of $13.8 \mathrm{mg}(0.0237 \mathrm{mmol}, 49 \%)$. $[\alpha]^{25} \mathrm{D}$ +153 (c $0.129 \mathrm{EtOH}) ;{ }^{1} \mathrm{H}$ NMR $\left(400 \mathrm{MHz}\right.$, acetone- $\left.d_{6}\right) \delta 12.60$ (s, $\left.1 \mathrm{H}\right), 8.75$ (br.s, $\left.1 \mathrm{H}\right), 8.51$ (d, $J=9.2$ Hz, 1H), 8.47 (br.s, 1H), 8.31 (br.s, 1H), 8.10 (br.s, 1H), 7.81 (br.s, 2H), 7.35 (d, J = 8.4 Hz, 1H), 7.22 (d, $J=16.4 \mathrm{~Hz}, 1 \mathrm{H}), 6.98(\mathrm{~d}, J=8.4 \mathrm{~Hz}, 1 \mathrm{H}), 6.76(\mathrm{~d}, J=16.4 \mathrm{~Hz}, 1 \mathrm{H}), 6.50(\mathrm{~d}, J=2.4 \mathrm{~Hz}, 1 \mathrm{H}), 6.43(\mathrm{~s}$, $2 \mathrm{H}), 6.40(\mathrm{~d}, J=2.4 \mathrm{~Hz}, 1 \mathrm{H}), 6.36(\mathrm{dd}, J=2.4,6.8 \mathrm{~Hz}, 1 \mathrm{H}), 6.34(\mathrm{dd}, J=2.4,6.0 \mathrm{~Hz}, 1 \mathrm{H}), 6.30(\mathrm{dd}, J=$ 2.4, $8.4 \mathrm{~Hz}, 1 \mathrm{H}), 6.23(\mathrm{~d}, J=2.4 \mathrm{~Hz}, 1 \mathrm{H}), 5.76(\mathrm{~s}, 1 \mathrm{H}), 4.61(\mathrm{dd}, J=4.0,5.2 \mathrm{~Hz}, 1 \mathrm{H}), 4.10(\mathrm{~s}, 1 \mathrm{H}), 3.74$ $(\mathrm{dd}, J=3.2,3.6 \mathrm{~Hz}, 1 \mathrm{H}), 2.48(\mathrm{~d}, J=18.0 \mathrm{~Hz}, 1 \mathrm{H}), 2.20(\mathrm{dd}, J=2.4,16.4 \mathrm{~Hz}, 1 \mathrm{H}), 1.92(\mathrm{~s}, 3 \mathrm{H}) ;{ }^{13} \mathrm{C}$ NMR $\left(100 \mathrm{MHz}\right.$, acetone- $\left.d_{6}\right) \delta 209.6,167.0,165.8,158.9,157.8,157.5,156.7,156.3,139.1,135.0$, 133.7, 128.7, 128.1, 125.9, 124.6, 123.8, 121.9, 117.3, 114.8, 113.7, 108.6, 108.3, 107.4, 106.5, 103.5, 103.4, 47.9, 36.2, 33.1, 32.4, 23.8; IR (neat): $v_{\max }\left(\mathrm{cm}^{-1}\right) 3293,1685,1597,1517,1443,1256,1212,1166$, 1031, 970, 839; HRMS (ESI) [M+H] ${ }^{+}$calculated for $\mathrm{C}_{34} \mathrm{H}_{30} \mathrm{O}_{9}: 583.1963$, found: 583.1967 .

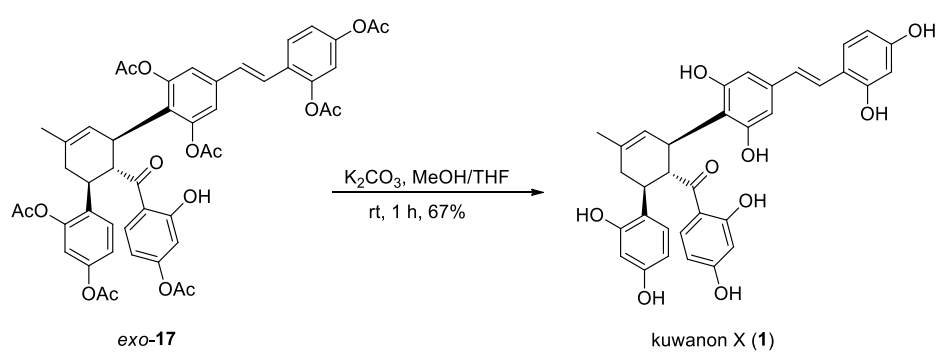

\section{Kuwanon X (1)}

To a solution of exo-17 $(107 \mathrm{mg}, 0.122 \mathrm{mmol})$ in THF $(0.7 \mathrm{~mL})$ and $\mathrm{MeOH}(1.4 \mathrm{~mL})$ was added $\mathrm{K}_{2} \mathrm{CO}_{3}$ (169 mg, $1.22 \mathrm{mmol}$ ) at room temperature. The reaction was quenched by $10 \% \mathrm{HCOOH}$ aqueous solution after $1 \mathrm{~h}$, and the resulting mixture was extracted with EtOAc. The combined organic layers were washed by saturated $\mathrm{NaHCO}_{3}$ solution, followed by brine, dried over $\mathrm{Na}_{2} \mathrm{SO}_{4}$, and concentrated in vacuo. After purification by flash column chromatography $\left(\mathrm{CH}_{2} \mathrm{Cl}_{2} / \mathrm{MeOH}=95: 5\right)$, kuwanon $\mathrm{X}$ (1) was obtained as an amorphous solid in a yield of $48.1 \mathrm{mg}(0.0826 \mathrm{mmol}, 68 \%)$. [ $\alpha]^{25} \mathrm{D}-274(\mathrm{c} 0.050 \mathrm{MeOH})$; ${ }^{1} \mathrm{H}$ NMR $\left(500 \mathrm{MHz}\right.$, DMSO- $\left.d_{6}, 120{ }^{\circ} \mathrm{C}\right) \delta 12.80$ (s, 1H), 9.64 (br.s, $1 \mathrm{H}$ ), 8.91 (br.s, $1 \mathrm{H}$ ), 8.77 (br.s, $1 \mathrm{H}$ ), $8.39(\mathrm{~s}, 1 \mathrm{H}), 8.33(\mathrm{~s}, 2 \mathrm{H}), 8.24(\mathrm{~s}, 1 \mathrm{H}), 7.58(\mathrm{~d}, J=9.0 \mathrm{~Hz}, 1 \mathrm{H}), 7.20(\mathrm{~d}, J=8.5 \mathrm{~Hz}, 1 \mathrm{H}), 7.0(\mathrm{~d}, J=16.5$ $\mathrm{Hz}, 1 \mathrm{H}), 6.71(\mathrm{~d}, J=8.5 \mathrm{~Hz}, 1 \mathrm{H}), 6.59$ (d, $J=16.5 \mathrm{~Hz}, 1 \mathrm{H}), 6.30$ (d, $J=2.5 \mathrm{~Hz}, 1 \mathrm{H}), 6.27$ (s, 2H), 6.23 $(\mathrm{dd}, J=2.0,8.0 \mathrm{~Hz}, 1 \mathrm{H}), 6.10(\mathrm{~d}, J=2.5 \mathrm{~Hz}, 1 \mathrm{H}), 5.99(\mathrm{dd}, J=2.5,8.5 \mathrm{~Hz}, 1 \mathrm{H}), 5.94(\mathrm{dd}, J=2.5,8.5$ $\mathrm{Hz}, 1 \mathrm{H}), 5.90(\mathrm{~d}, J=2.5 \mathrm{~Hz}, 1 \mathrm{H}), 5.20(\mathrm{~s}, 1 \mathrm{H}), 4.76(\mathrm{t}, J=10.5 \mathrm{~Hz}, 1 \mathrm{H}), 4.31(\mathrm{~d}, J=8.0 \mathrm{~Hz}, 1 \mathrm{H}), 3.52$ (td, $J=5.0,11.5 \mathrm{~Hz}, 1 \mathrm{H}), 2.40$ (br. d, $J=12.5 \mathrm{~Hz}, 1 \mathrm{H}), 2.05(\mathrm{dd}, J=4.5,17.0 \mathrm{~Hz}, 1 \mathrm{H}), 1.67(\mathrm{~s}, 3 \mathrm{H}) ;{ }^{13} \mathrm{C}$ 
NMR $\left(125 \mathrm{MHz}\right.$, DMSO- $\left.d_{6}, 120{ }^{\circ} \mathrm{C}\right) \delta 208.2,163.6,163.2,157.4,155.7,155.4,155.3,154.9,136.6$, 132.2, 130.6, 128.0, 126.4, 124.5, 124.4, 122.5, 120.5, 115.6, 114.5, 114.2, 106.9, 106.3, 105.8, 104.4, 102.7, 101.3, 45.5, 38.3, 37.0, 36.7, 22.0; IR (neat): $v_{\max }\left(\mathrm{cm}^{-1}\right)$ 3365, 2924, 1698, 1613, 1454, 1368, 1232,973, 669; HRMS (ESI) [M+H] ${ }^{+}$calculated for $\mathrm{C}_{34} \mathrm{H}_{30} \mathrm{O}_{9}: 583.1963$, found: 583.1970 .

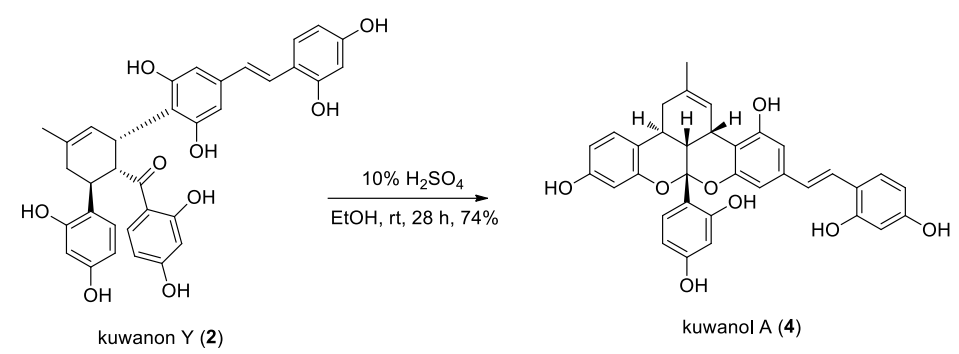

\section{Kuwanol A (4)}

To a solution of $2(12.2 \mathrm{mg}, 0.0210 \mathrm{mmol})$ in EtOH $(6 \mathrm{~mL}), 10 \% \mathrm{H}_{2} \mathrm{SO}_{4}$ aqueous solution $(1.2 \mathrm{~mL})$ was added dropwise. The reaction mixture was stirred at room temperature for $28 \mathrm{~h}$ and then quenched by saturated $\mathrm{NaHCO}_{3}$ solution. The resulting mixture was extracted with EtOAc, washed by brine, dried over $\mathrm{Na}_{2} \mathrm{SO}_{4}$, and concentrated in vacuo. After purification by flash column chromatography $\left(\mathrm{CH}_{2} \mathrm{Cl}_{2} / \mathrm{MeOH}=96: 4\right)$, kuwanol A (4) was obtained as an amorphous solid in a yield of $8.7 \mathrm{mg}(0.0154$ mmol, 73\%). $[\alpha]^{26} \mathrm{D}+394$ (c $0.111 \mathrm{MeOH}$ ); ${ }^{1} \mathrm{H}$ NMR (400 MHz, acetone- $\left.d_{6}\right) \delta 8.53$ (br.s, $1 \mathrm{H}$ ), 8.43-8.35 (m, 3H), 8.25 (br.s, 1H), 7.39 (d, $J=8.8 \mathrm{~Hz}, 1 \mathrm{H}), 7.32(\mathrm{~d}, J=16.4 \mathrm{~Hz}, 1 \mathrm{H}), 7.23$ (d, $J=8.4 \mathrm{~Hz}, 1 \mathrm{H})$, $7.13(\mathrm{dd}, J=0.8,8.8 \mathrm{~Hz}, 1 \mathrm{H}), 6.88(\mathrm{~d}, J=16.4 \mathrm{~Hz}, 1 \mathrm{H}), 6.64(\mathrm{~d}, J=1.6 \mathrm{~Hz}, 1 \mathrm{H}), 6.61(\mathrm{~d}, J=1.6 \mathrm{~Hz}$, $1 \mathrm{H}), 6.49(\mathrm{dd}, J=2.4,8.4 \mathrm{~Hz}, 1 \mathrm{H}), 6.45(\mathrm{~s}, 1 \mathrm{H}), 6.43(\mathrm{~d}, J=2.0 \mathrm{~Hz}, 1 \mathrm{H}), 6.39(\mathrm{~d}, J=2.4 \mathrm{~Hz}, 1 \mathrm{H}), 6.37$ (dd, $J=2.4,8.4 \mathrm{~Hz}, 1 \mathrm{H}), 6.35$ (d, $J=2.8 \mathrm{~Hz}, 1 \mathrm{H}), 6.23$ (dd, $J=2.4,8.8 \mathrm{~Hz}, 1 \mathrm{H}), 3.47$ (s, 1H), 3.29 (dd, $J=5.6,12.0 \mathrm{~Hz}, 1 \mathrm{H}), 2.98(\mathrm{td}, J=5.2,11.6 \mathrm{~Hz}, 1 \mathrm{H}), 2.70(\mathrm{dd}, J=5.6,17.2 \mathrm{~Hz}, 1 \mathrm{H}), 2.03-2.01(\mathrm{~m}, 1 \mathrm{H})$, 1.77 (s, 3H); ${ }^{13} \mathrm{C}$ NMR (100 MHz, acetone- $\left.d_{6}\right) \delta 159.8,159.1,157.7,157.6,157.5,156.9,154.1,153.4$, 139.4, 133.3, 130.3, 128.3, 127.8, 125.6, 124.4, 123.2, 117.6, 117.2, 117.1, 111.9, 109.7, 108.4, 107.1, 107.0, 106.8, 104.6, 103.9, 103.5, 102.5, 37.2, 36.2, 35.1, 28.4, 23.9; IR (neat): $v_{\max }\left(\mathrm{cm}^{-1}\right)$ 3332, 2923, 1686, 1609, 1510, 1456, 1258, 1166, 1149, 1125, 1020, 969; HRMS (ESI) $[\mathrm{M}+\mathrm{H}]+{ }^{+}$calculated for $\mathrm{C}_{34} \mathrm{H}_{28} \mathrm{O}_{8}: 565.1857$, found: 565.1862 .

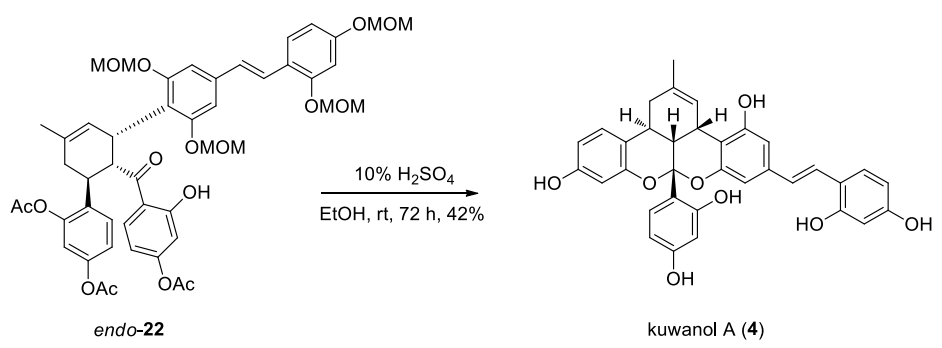

\section{Kuwanol A (4)}

To a solution of endo-22 $(15.1 \mathrm{mg}, 0.0170 \mathrm{mmol})$ in $\mathrm{EtOH}(3.75 \mathrm{~mL}), 10 \% \mathrm{H}_{2} \mathrm{SO}_{4}$ aqueous solution $(0.75 \mathrm{~mL})$ was added dropwise at room temperature. The reaction mixture was stirred for $72 \mathrm{~h}$ and then quenched by saturated $\mathrm{NaHCO}_{3}$ solution. The resulting mixture was extracted with EtOAc, washed by brine, dried over $\mathrm{Na}_{2} \mathrm{SO}_{4}$, and concentrated in vacuo. After purification by flash column chromatography $\left(\mathrm{CH}_{2} \mathrm{Cl}_{2} / \mathrm{MeOH}=96: 4\right)$, kuwanol $\mathrm{A}(\mathbf{4})$ was obtained as an amorphous solid in a yield of $4.0 \mathrm{mg}$ (0.00709 mmol, 42\%). 


\section{IV) Comparison of Natural and Synthetic Kuwanons X and Y, Kuwanol A}

NMR data comparison of natural and synthetic kuwanon $\mathrm{X}$

${ }^{1} \mathrm{H}$ NMR $(\mathrm{Hz}) \mathrm{DMSO}-d_{6} 120^{\circ} \mathrm{C}$

\begin{tabular}{|l|l|l|l|}
\hline Natural $(270 \mathrm{MHz})$ & Synthetic $(500 \mathrm{MHz})$ & Natural $(270 \mathrm{MHz})$ & Synthetic $(500 \mathrm{MHz})$ \\
\hline $13.11\left(\mathrm{~s}, 1 \mathrm{H}, 21^{\circ} \mathrm{C}\right)$ & $12.80(\mathrm{~s}, 1 \mathrm{H})$ & $6.27(\mathrm{~s}, 2 \mathrm{H})$ & $6.27(\mathrm{~s}, 2 \mathrm{H})$ \\
\hline- & $9.64(\mathrm{br} . \mathrm{s}, 1 \mathrm{H})$ & $6.23(\mathrm{dd}, J=2.6,8.5,1 \mathrm{H})$ & $6.23(\mathrm{dd}, J=2.0,8.0,1 \mathrm{H})$ \\
\hline- & $8.91($ br.s, $1 \mathrm{H})$ & $6.11(\mathrm{~d}, J=2.1,1 \mathrm{H})$ & $6.10(\mathrm{~d}, J=2.5,1 \mathrm{H})$ \\
\hline- & $8.77($ br.s, $1 \mathrm{H})$ & $6.00(\mathrm{dd}, J=2.5,8.8,1 \mathrm{H})$ & $5.99(\mathrm{dd}, J=2.5,8.5,1 \mathrm{H})$ \\
\hline- & $8.39($ br.s, $1 \mathrm{H})$ & $5.94(\mathrm{dd}, J=2.1,8.3,1 \mathrm{H})$ & $5.94(\mathrm{dd}, J=2.5,8.5,1 \mathrm{H})$ \\
\hline- & $8.33(\mathrm{br.s}, 2 \mathrm{H})$ & $5.90(\mathrm{~d}, J=2.5,1 \mathrm{H})$ & $5.90(\mathrm{~d}, J=2.5,1 \mathrm{H})$ \\
\hline- & $8.24(\mathrm{br} . \mathrm{s}, 1 \mathrm{H})$ & $5.20(\mathrm{br} . \mathrm{s}, 1 \mathrm{H})$ & $5.20(\mathrm{br} . \mathrm{s}, 1 \mathrm{H})$ \\
\hline $7.59(\mathrm{~d}, J=8.8,1 \mathrm{H})$ & $7.58(\mathrm{~d}, J=9.0,1 \mathrm{H})$ & $4.78(\mathrm{br} . \mathrm{t}, J=10.0,1 \mathrm{H})$ & $4.76(\mathrm{br} . \mathrm{t}, J=10.5,1 \mathrm{H})$ \\
\hline $7.21(\mathrm{~d}, J=8.5,1 \mathrm{H})$ & $7.20(\mathrm{~d}, J=8.5,1 \mathrm{H})$ & $4.30(\mathrm{br} . \mathrm{d}, J=10.0,1 \mathrm{H})$ & $4.31(\mathrm{br} . \mathrm{d}, J=8.0,1 \mathrm{H})$ \\
\hline $6.99(\mathrm{~d}, J=16.0,1 \mathrm{H})$ & $7.00(\mathrm{~d}, J=16.5,1 \mathrm{H})$ & $3.50(\mathrm{ddd}, J=5.0,10.0$, & $3.52(\mathrm{td}, J=5.0,11.5,1 \mathrm{H})$ \\
\hline $6.71(\mathrm{~d}, J=8.3,1 \mathrm{H})$ & $6.71(\mathrm{~d}, J=8.5,1 \mathrm{H})$ & $2.38(\mathrm{dd}, J=13.0,16.0,1 \mathrm{H})$ & $2.40(\mathrm{br} . \mathrm{d}, J=12.5,1 \mathrm{H})$ \\
\hline $6.56(\mathrm{~d}, J=16.0,1 \mathrm{H})$ & $6.59(\mathrm{~d}, J=16.5,1 \mathrm{H})$ & $2.05(\mathrm{dd}, J=5.0,16.0,1 \mathrm{H})$ & $2.05(\mathrm{dd}, J=4.5,17.0,1 \mathrm{H})$ \\
\hline $6.31(\mathrm{~d}, J=2.6,1 \mathrm{H})$ & $6.30(\mathrm{~d}, J=2.5,1 \mathrm{H})$ & $1.67(\mathrm{~s}, 3 \mathrm{H})$ & $1.67(\mathrm{~s}, 3 \mathrm{H})$ \\
\hline
\end{tabular}

${ }^{13} \mathrm{C}$ NMR $(\mathrm{Hz})$ DMSO- $d_{6} 120^{\circ} \mathrm{C} *$

\begin{tabular}{|l|l|l|l|}
\hline Natural $(67.5 \mathrm{MHz})$ & Synthetic $(125 \mathrm{MHz})$ & Natural $(67.5 \mathrm{MHz})$ & Synthetic $(125 \mathrm{MHz})$ \\
\hline 208.9 & 208.7 & 121.1 & 121.0 \\
\hline 164.2 & 164.1 & 116.2 & 116.1 \\
\hline 163.9 & 163.7 & 115.2 & 115.0 \\
\hline 158.1 & 157.9 & 114.9 & 114.7 \\
\hline 156.4 & 156.2 & 107.6 & 107.4 \\
\hline 156.0 & 155.9 & 107.0 & 106.8 \\
\hline 155.9 & 155.8 & 106.4 & 106.3 \\
\hline 155.6 & 155.4 & 105.0 & 104.9 \\
\hline 137.2 & 137.1 & 103.4 & 103.2 \\
\hline 132.9 & 132.7 & $102.0 * *$ & 101.8 \\
\hline 131.2 & 131.1 & 46.1 & 46.0 \\
\hline 128.7 & 128.5 & 39.0 & 38.8 \\
\hline 127.1 & 126.9 & 37.7 & 37.5 \\
\hline 125.2 & 125.0 & 37.4 & 37.2 \\
\hline 125.1 & 124.9 & 22.7 & 22.5 \\
\hline 123.1 & 123.0 & & \\
\hline
\end{tabular}

*Date shown for synthetic kuwanon X has been referenced to DMSO- $d 6(\delta 40.0)$ for comparison **Chemical shift of this carbon was recorded as 102.0 in 'Hano, Y.; Tsubura, H.; Nomura, T. Heterocycles 1986, 24, 2603' but 120.0 in 'Hirakura, K.; Hano, Y.; Fukai, T. Chem. Pharm. Bull. 1985, 33, 1088.' 
$[\alpha]_{D}$ of Natural and Synthetic Kuwanon X

\begin{tabular}{|l|l|}
\hline Natural Kuwanon $X$ & Synthetic Kuwanon $X$ \\
\hline$[\alpha]^{21} \mathrm{D}-322(\mathrm{c}=0.049$ in $\mathrm{MeOH})$ & {$[\alpha]^{25} \mathrm{D}-274(\mathrm{c}=0.050$ in $\mathrm{MeOH})$} \\
\hline
\end{tabular}

\section{NMR data comparison of natural and synthetic kuwanon $\mathbf{Y}$}

${ }^{1} \mathrm{H}$ NMR $(\mathrm{Hz})$ acetone- $d_{6}$

\begin{tabular}{|l|l|l|l|}
\hline Natural & Synthetic $(400 \mathrm{MHz})$ & Natural & Synthetic $(400 \mathrm{MHz})$ \\
\hline- & $12.60(\mathrm{br} . \mathrm{s}, 1 \mathrm{H})$ & $6.40(\mathrm{~d}, J=2.0,1 \mathrm{H})$ & $6.40(\mathrm{~d}, J=2.4,1 \mathrm{H})$ \\
\hline- & $8.75(\mathrm{br} . \mathrm{s}, 1 \mathrm{H})$ & $6.36(\mathrm{dd}, J=2.0,8.0,1 \mathrm{H})$ & $6.36(\mathrm{dd}, J=2.4,6.8,1 \mathrm{H})$ \\
\hline $8.52(\mathrm{~d}, J=8.0,1 \mathrm{H})$ & $8.51(\mathrm{~d}, J=9.2,1 \mathrm{H})$ & $6.35(\mathrm{dd}, J=2.0,8.0,1 \mathrm{H})$ & $6.34(\mathrm{dd}, J=2.4,6.0,1 \mathrm{H})$ \\
\hline- & $8.47(\mathrm{br.s}, 1 \mathrm{H})$ & $6.30(\mathrm{dd}, J=2.0,8.0,1 \mathrm{H})$ & $6.30(\mathrm{dd}, J=2.4,8.4,1 \mathrm{H})$ \\
\hline- & $8.31(\mathrm{br} . \mathrm{s}, 1 \mathrm{H})$ & $6.24(\mathrm{~d}, J=2.0,1 \mathrm{H})$ & $6.23(\mathrm{~d}, J=2.4,1 \mathrm{H})$ \\
\hline- & $8.10(\mathrm{br} . \mathrm{s}, 1 \mathrm{H})$ & $5.76(\mathrm{~s}, 1 \mathrm{H})$ & $5.76(\mathrm{~s}, 1 \mathrm{H})$ \\
\hline- & $7.81(\mathrm{br} . \mathrm{s}, 2 \mathrm{H})$ & $4.60(\mathrm{dd}, J=4.0,5.0,1 \mathrm{H})$ & $4.61(\mathrm{dd}, J=4.0,5.2,1 \mathrm{H})$ \\
\hline $7.34(\mathrm{~d}, J=8.0,1 \mathrm{H})$ & $7.35(\mathrm{~d}, J=8.4,1 \mathrm{H})$ & $4.11(\mathrm{~d}, J=5.0,1 \mathrm{H})$ & $4.10(\mathrm{~s}, 1 \mathrm{H})$ \\
\hline $7.22(\mathrm{~d}, J=16.0,1 \mathrm{H})$ & $7.22(\mathrm{~d}, J=16.4,1 \mathrm{H})$ & $3.75(\mathrm{dd}, J=3.0,4.0, \mathrm{H})$ & $3.74(\mathrm{dd}, J=3.2,3.6, \mathrm{H})$ \\
\hline $6.98(\mathrm{~d}, J=8.0,1 \mathrm{H})$ & $6.98(\mathrm{~d}, J=8.4,1 \mathrm{H})$ & $2.49(\mathrm{~d}, J=18.0,1 \mathrm{H})$ & $2.48(\mathrm{~d}, J=18.0,1 \mathrm{H})$ \\
\hline $6.77(\mathrm{~d}, J=16.0,1 \mathrm{H})$ & $6.76(\mathrm{~d}, J=16.4,1 \mathrm{H})$ & $2.19(\mathrm{dd}, J=3.0,18.0,1 \mathrm{H})$ & $2.20(\mathrm{dd}, J=2.4,16.4,1 \mathrm{H})$ \\
\hline $6.50(\mathrm{~d}, J=2.0,1 \mathrm{H})$ & $6.50(\mathrm{~d}, J=2.4,1 \mathrm{H})$ & $1.92(\mathrm{~s}, 3 \mathrm{H})$ & $1.92(\mathrm{~s}, 3 \mathrm{H})$ \\
\hline $6.44(\mathrm{~s}, 2 \mathrm{H})$ & $6.43(\mathrm{~s}, 2 \mathrm{H})$ & & \\
\hline
\end{tabular}

${ }^{13} \mathrm{C}$ NMR $(\mathrm{Hz})$ acetone- $d_{6}$

\begin{tabular}{|l|l|l|l|}
\hline Natural & Synthetic $(100 \mathrm{MHz})$ & Natural & Synthetic $(100 \mathrm{MHz})$ \\
\hline 208.6 & 209.6 & 121.6 & 121.9 \\
\hline 166.2 & 167.0 & 116.9 & 117.3 \\
\hline 165.1 & 165.8 & 114.3 & 114.8 \\
\hline 158.3 & 158.9 & 113.3 & 113.7 \\
\hline 157.1 & 157.8 & 108.2 & 108.6 \\
\hline 156.8 & 157.5 & 107.9 & 108.3 \\
\hline 156.0 & 156.7 & 107.0 & 107.4 \\
\hline 155.6 & 156.3 & 106.1 & 106.5 \\
\hline 138.5 & 139.1 & 103.2 & 103.5 \\
\hline 134.4 & 135.0 & 103.1 & 103.4 \\
\hline 133.3 & 133.7 & 47.8 & 47.9 \\
\hline 128.2 & 128.7 & 36.0 & 36.2 \\
\hline 127.6 & 128.1 & 33.1 & 33.1 \\
\hline 125.5 & 125.9 & 32.4 & 32.4 \\
\hline 124.1 & 124.6 & 23.7 & 23.8 \\
\hline 123.3 & 123.8 & & \\
\hline
\end{tabular}

$[\alpha]_{D}$ of Natural and Synthetic Kuwanon Y

\begin{tabular}{|l|l|}
\hline Natural Kuwanon $\mathrm{Y}$ & Synthetic Kuwanon Y \\
\hline$[\alpha]^{22} \mathrm{D}+172(\mathrm{c}=0.129$ in EtOH $)$ & {$[\alpha]^{25} \mathrm{D}+153(\mathrm{c}=0.129$ in EtOH $)$} \\
\hline
\end{tabular}


NMR data comparison of natural and synthetic kuwanon A

${ }^{1} \mathrm{H}$ NMR $(\mathrm{Hz})$ acetone- $d_{6}$

\begin{tabular}{|l|l|l|l|}
\hline Natural $(400 \mathrm{MHz})$ & Synthetic $(400 \mathrm{MHz})$ & Natural $(400 \mathrm{MHz})$ & Synthetic $(400 \mathrm{MHz})$ \\
\hline- & $8.53(\mathrm{br.s}, 1 \mathrm{H})$ & $6.43(\mathrm{~d}, J=2.4,1 \mathrm{H})$ & $6.43(\mathrm{~d}, J=2.0,1 \mathrm{H})$ \\
\hline- & $8.43-8.35(\mathrm{~m}, 3 \mathrm{H})$ & $6.40(\mathrm{~d}, J=2.4,1 \mathrm{H})$ & $6.39(\mathrm{~d}, J=2.4,1 \mathrm{H})$ \\
\hline- & $8.25(\mathrm{br} . \mathrm{s}, 1 \mathrm{H})$ & $6.38(\mathrm{dd}, J=2.4,8.4,1 \mathrm{H})$ & $6.37(\mathrm{dd}, J=2.4,8.4,1 \mathrm{H})$ \\
\hline $7.39(\mathrm{~d}, J=8.4,1 \mathrm{H})$ & $7.39(\mathrm{~d}, J=8.8,1 \mathrm{H})$ & $6.35(\mathrm{~d}, J=2.4,1 \mathrm{H})$ & $6.35(\mathrm{~d}, J=2.8,1 \mathrm{H})$ \\
\hline $7.32(\mathrm{~d}, J=16.5,1 \mathrm{H})$ & $7.32(\mathrm{~d}, J=16.4,1 \mathrm{H})$ & $6.23(\mathrm{dd}, J=2.4,8.6,1 \mathrm{H})$ & $6.23(\mathrm{dd}, J=2.4,8.8,1 \mathrm{H})$ \\
\hline $7.23(\mathrm{~d}, J=8.6,1 \mathrm{H})$ & $7.23(\mathrm{~d}, J=8.4,1 \mathrm{H})$ & $3.47(\mathrm{dd}, J=5.0,5.9,1 \mathrm{H})$ & $3.47(\mathrm{~s}, 1 \mathrm{H})$ \\
\hline $7.13(\mathrm{~d}, J=8.4,1 \mathrm{H})$ & $7.13(\mathrm{dd}, J=0.8,8.8,1 \mathrm{H})$ & $3.30(\mathrm{dd}, J=5.9,11.9$, & $3.29(\mathrm{dd}, J=5.6,12.0$, \\
& & $1 \mathrm{H})$ & $1 \mathrm{H})$ \\
\hline $6.88(\mathrm{~d}, J=16.5,1 \mathrm{H})$ & $6.88(\mathrm{~d}, J=16.4,1 \mathrm{H})$ & $3.00(\mathrm{ddd}, J=5.0,11.9$, & $\begin{array}{l}2.98(\mathrm{td}, J=5.2,11.6, \\
\end{array}$ \\
\hline $6.64(\mathrm{~d}, J=1.5,1 \mathrm{H})$ & $6.64(\mathrm{~d}, J=1.6,1 \mathrm{H})$ & $2.70(\mathrm{dd}, J=5.0,17.1$, & $2.70(\mathrm{dd}, J=5.6,17.2$, \\
& & $1 \mathrm{H})$ & $1 \mathrm{H})$ \\
\hline $6.62(\mathrm{~d}, J=1.5,1 \mathrm{H})$ & $6.61(\mathrm{~d}, J=1.6,1 \mathrm{H})$ & $2.00(\mathrm{dd}, J=12.0,17.1$, & $2.03-2.01(\mathrm{~m}, 1 \mathrm{H})$ \\
\hline $6.49(\mathrm{dd}, J=2.4,8.4,1 \mathrm{H})$ & $6.49(\mathrm{dd}, J=2.4,8.4,1 \mathrm{H})$ & $1.77(\mathrm{~s}, 3 \mathrm{H})$ & $1.77(\mathrm{~s}, 3 \mathrm{H})$ \\
\hline $6.44(\mathrm{~d}, J=5.0,1 \mathrm{H})$ & $6.45(\mathrm{~s}, 1 \mathrm{H})$ & & \\
\hline
\end{tabular}

${ }^{13} \mathrm{C}$ NMR $(\mathrm{Hz})$ acetone- $d_{6}$

\begin{tabular}{|l|l|l|l|}
\hline Natural & Synthetic $(100 \mathrm{MHz})$ & Natural & Synthetic $(100 \mathrm{MHz})$ \\
\hline 159.3 & 159.8 & 116.7 & 117.2 \\
\hline 158.4 & 159.1 & 116.6 & 117.1 \\
\hline 157.2 & 157.7 & 111.4 & 111.9 \\
\hline 157.0 & 157.6 & 109.3 & 109.7 \\
\hline 156.9 & 157.5 & 108.0 & 108.4 \\
\hline 156.9 & 156.9 & 106.7 & 107.1 \\
\hline 153.4 & 154.1 & 106.7 & 107.0 \\
\hline 152.5 & 153.4 & 106.4 & 106.8 \\
\hline 138.8 & 139.4 & 104.2 & 104.6 \\
\hline 132.7 & 133.3 & 103.5 & 103.9 \\
\hline 129.7 & 130.3 & 103.2 & 103.5 \\
\hline 127.8 & 128.3 & 102.1 & 102.5 \\
\hline 127.2 & 127.8 & 37.2 & 37.2 \\
\hline 125.1 & 125.6 & 36.1 & 36.2 \\
\hline 124.0 & 124.4 & 35.0 & 35.1 \\
\hline 122.7 & 123.2 & 28.4 & 28.4 \\
\hline 117.1 & 117.6 & 23.8 & 23.9 \\
\hline
\end{tabular}

$[\alpha]_{D}$ of Natural and Synthetic Kuwanon A

\begin{tabular}{|l|l|}
\hline Natural Kuwanol A & Synthetic Kuwanol A \\
\hline$[\alpha]^{24} \mathrm{D}+557(\mathrm{c}=0.111$ in $\mathrm{MeOH})$ & {$[\alpha]^{26} \mathrm{D}+394(\mathrm{c}=0.111$ in $\mathrm{MeOH})$} \\
\hline
\end{tabular}




\section{V) ${ }^{1} \mathrm{H},{ }^{13} \mathrm{C}$ NMR Spectra}

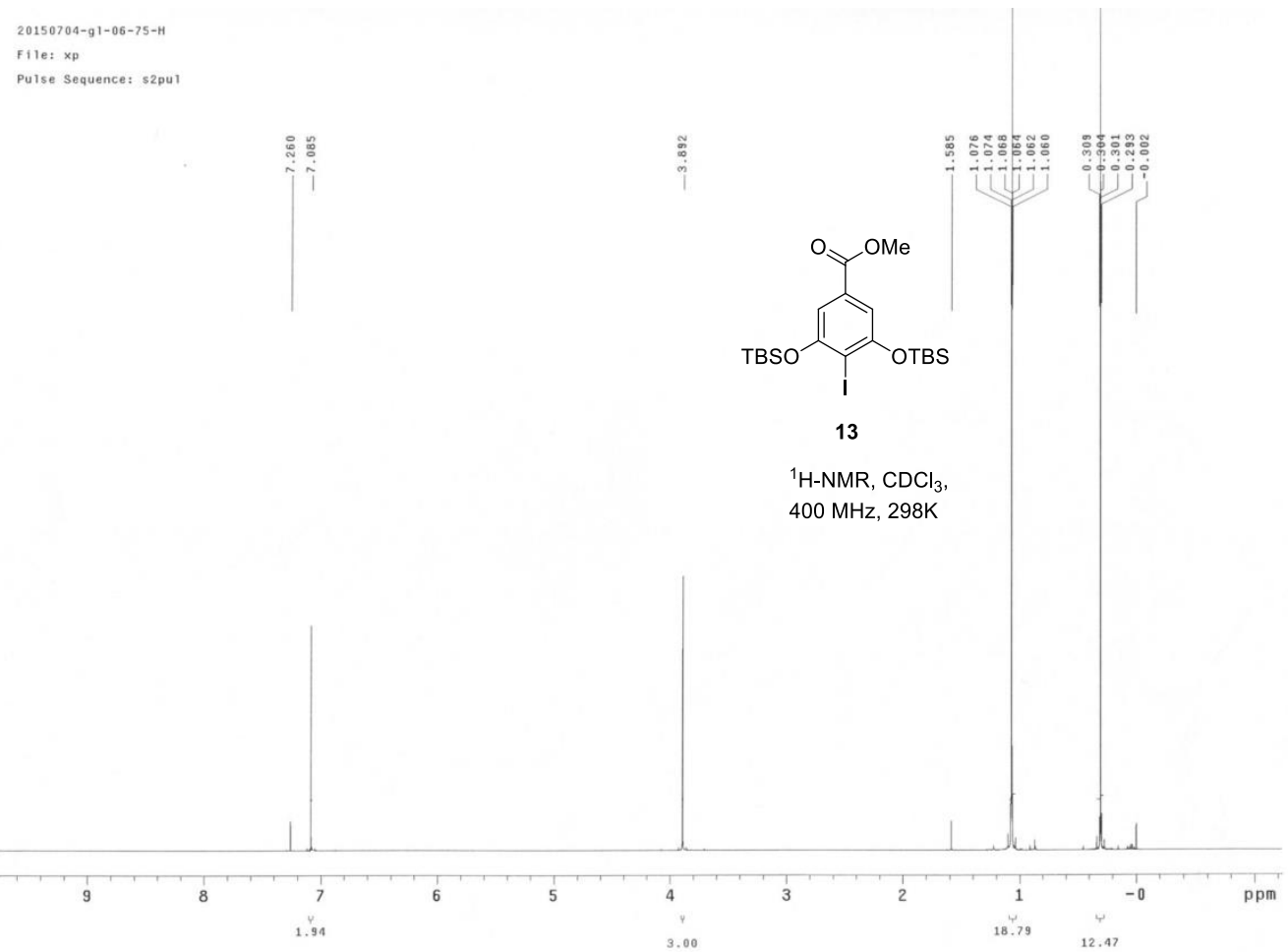

20150704-91-06-75-C

File: home/vnnr1/vnarsys/data-Lei/gaolei/20150704-g1-06-75-C.fif

Pulse Sequence: s2pul

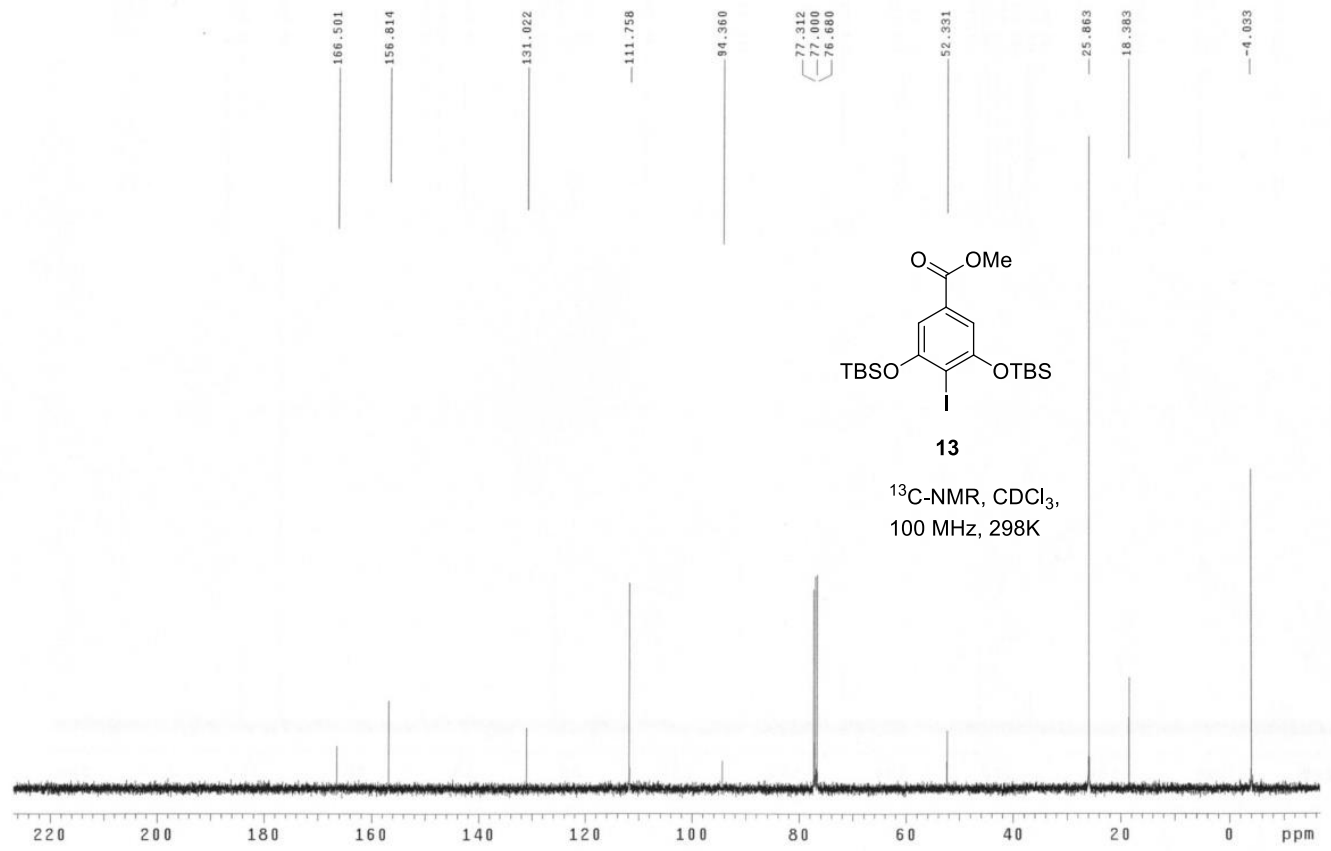




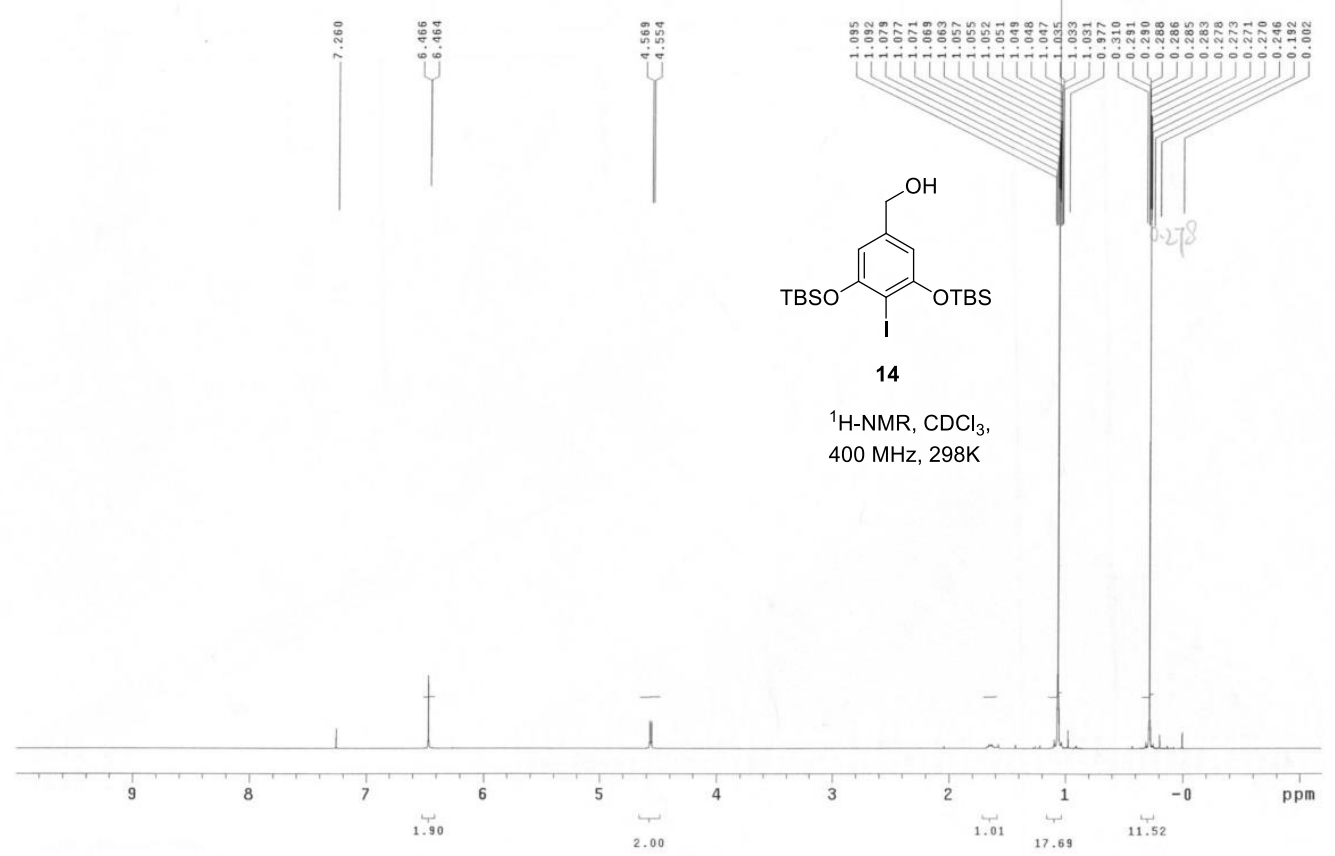

20150702-91-06-73-C

File: $x p$

Pulse Sequence: s2pul

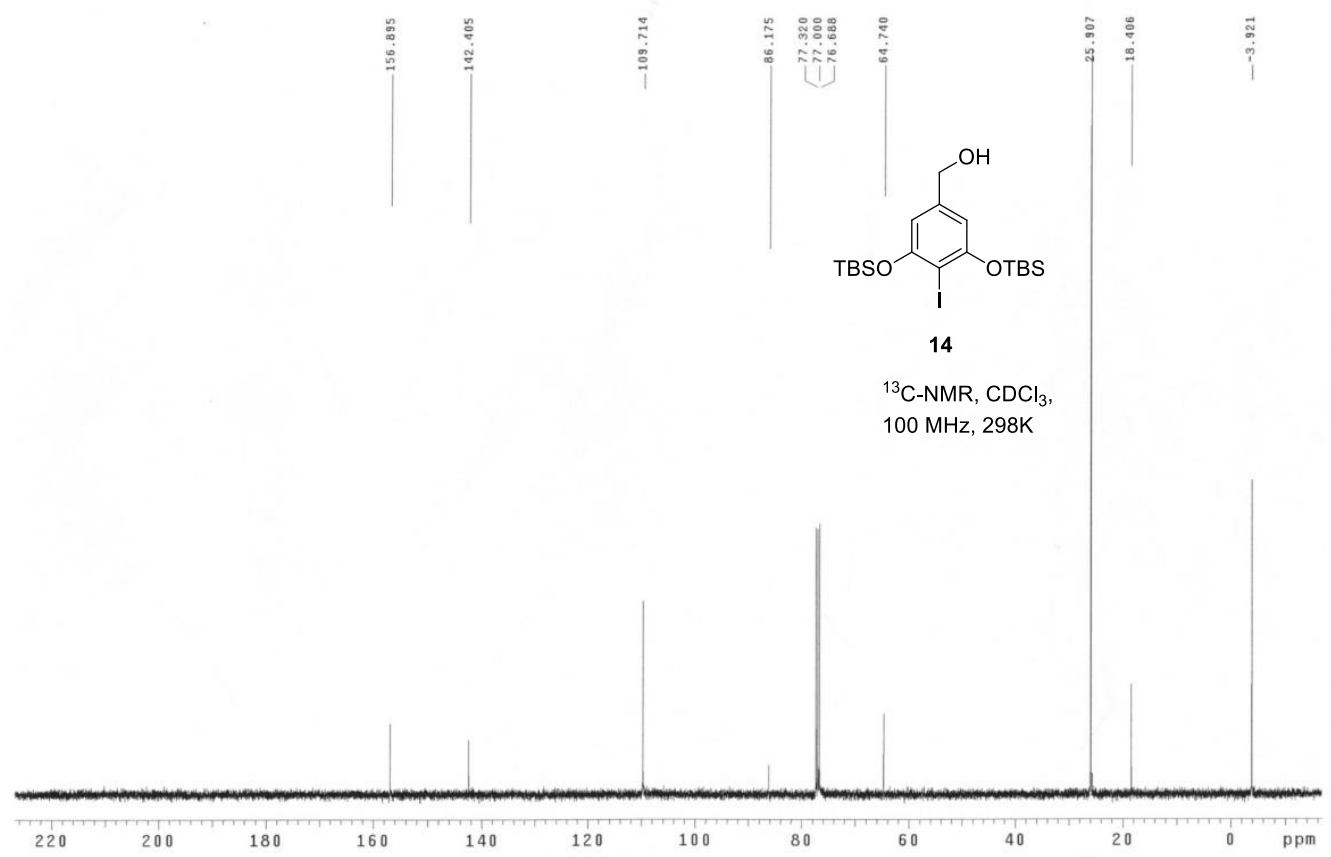


Pulse Sequence: 52pur

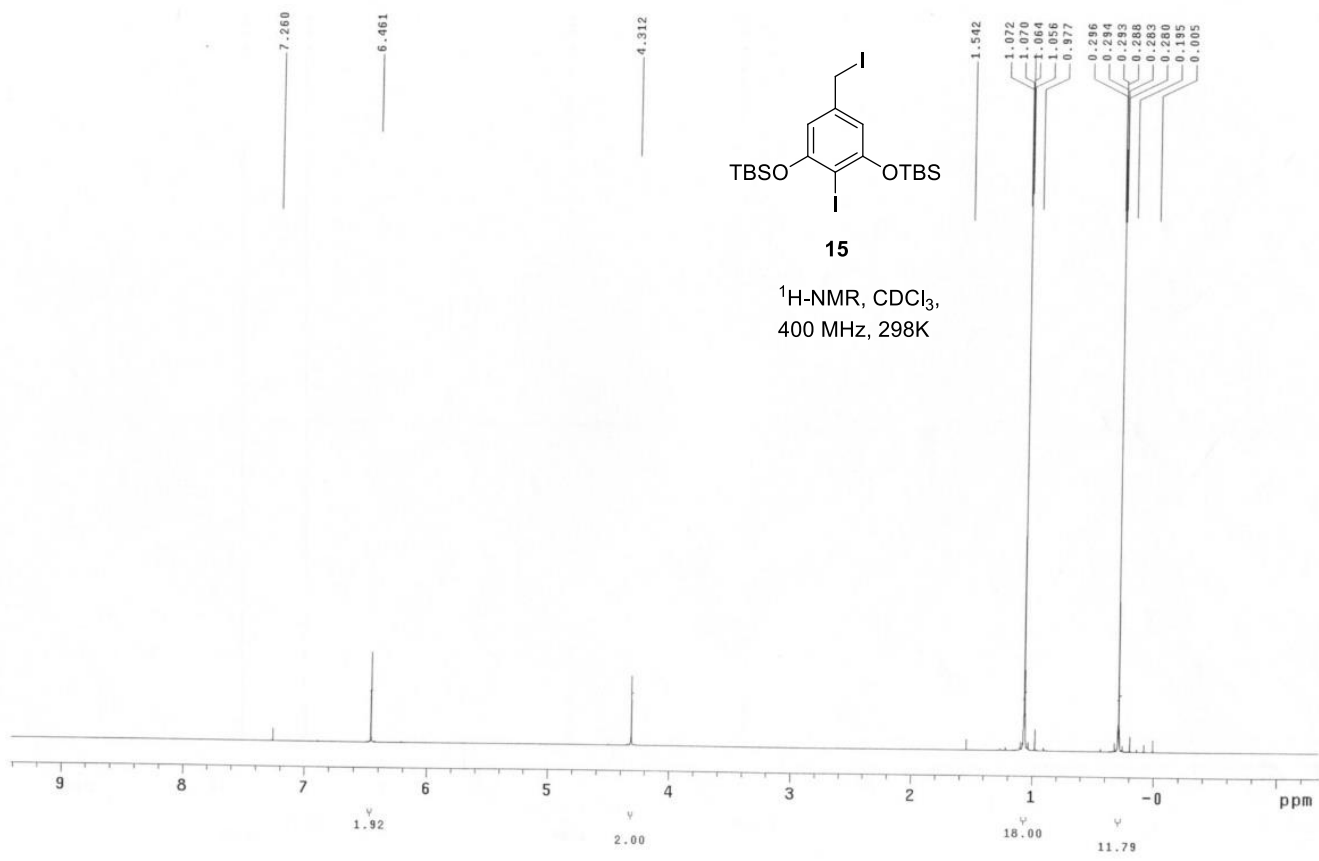

20150704-91-06-74-1

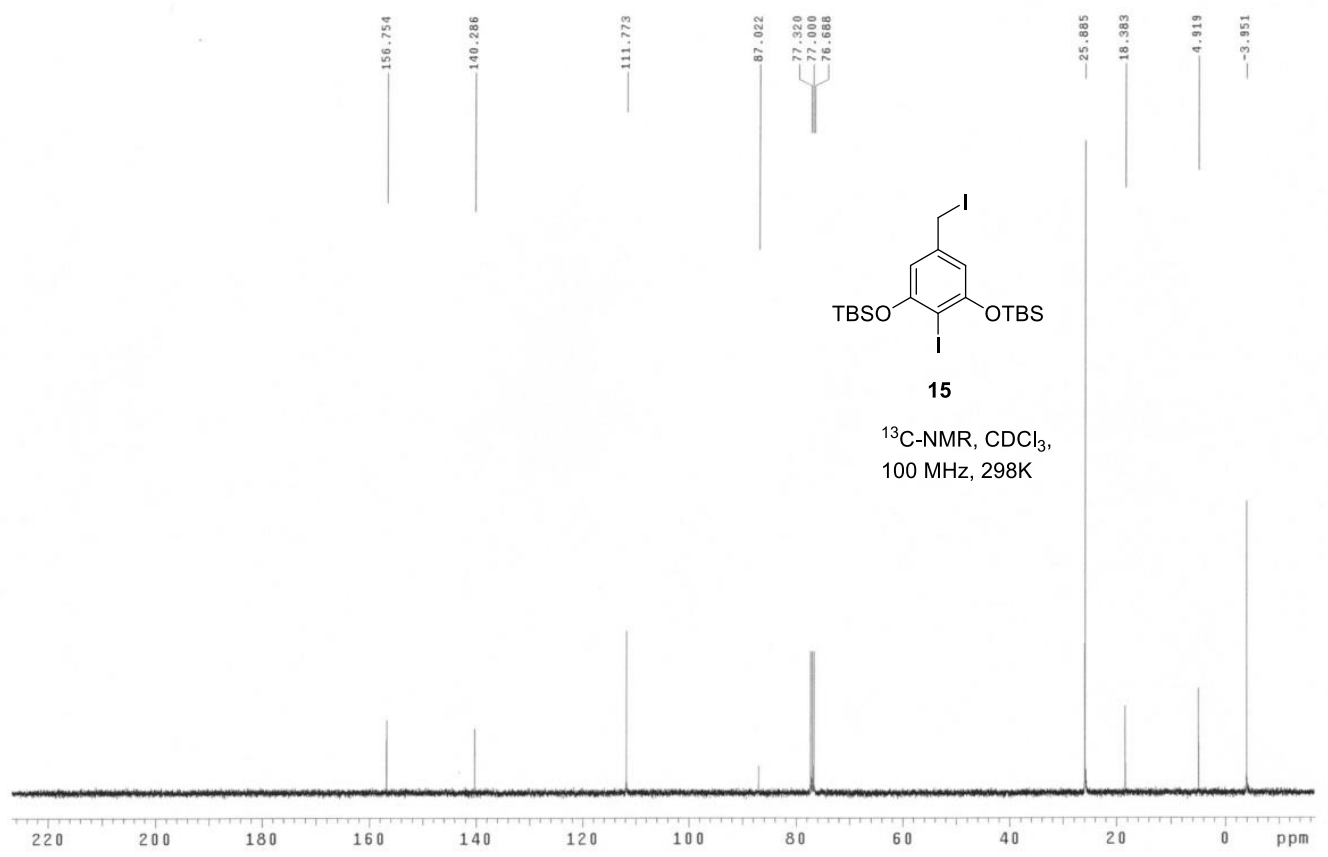


file: $x p$

Puise Sequence: s2pul
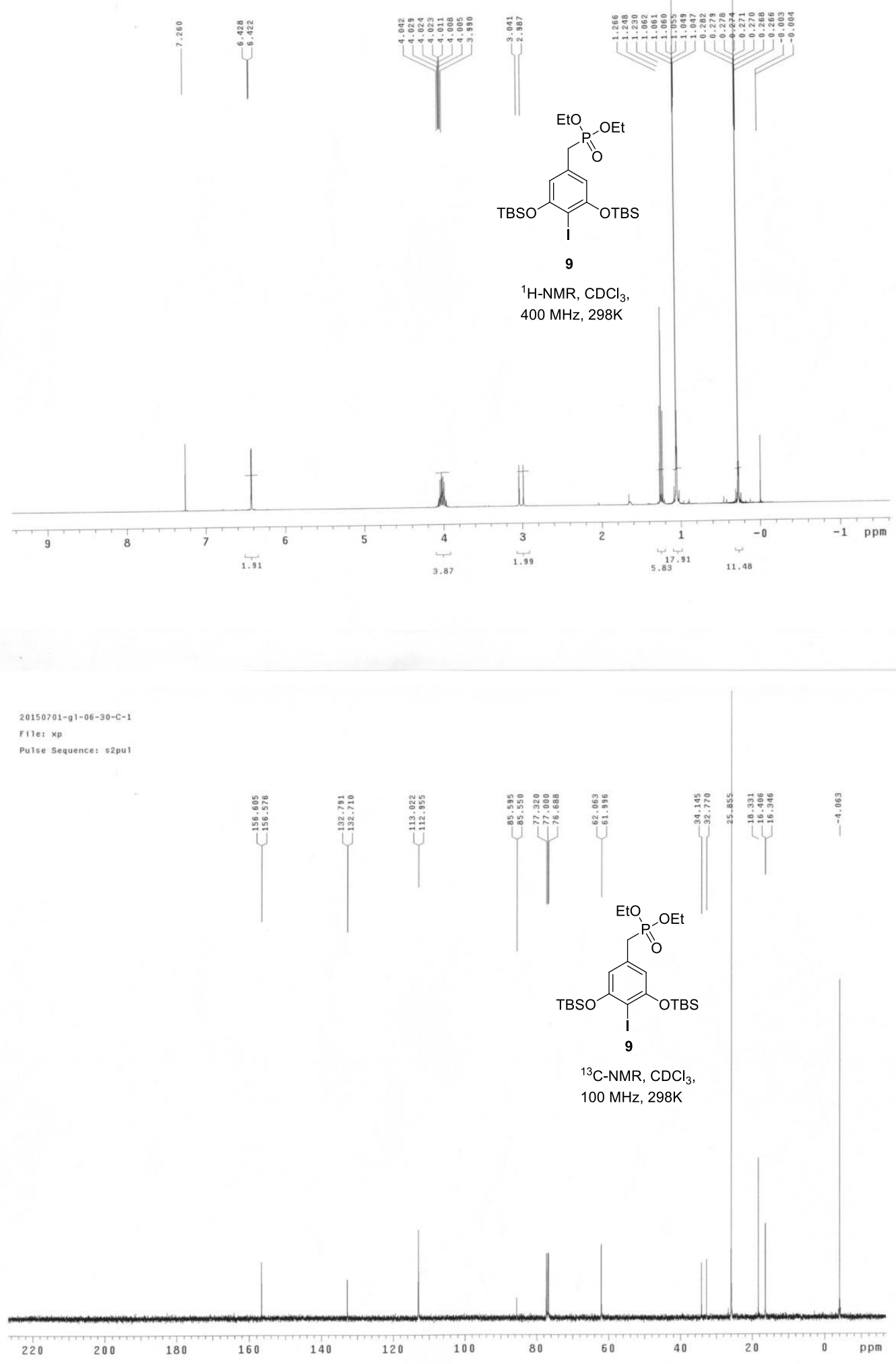
20150724-91-06-86-H-1

File:

Pulse Sequence: 52pul

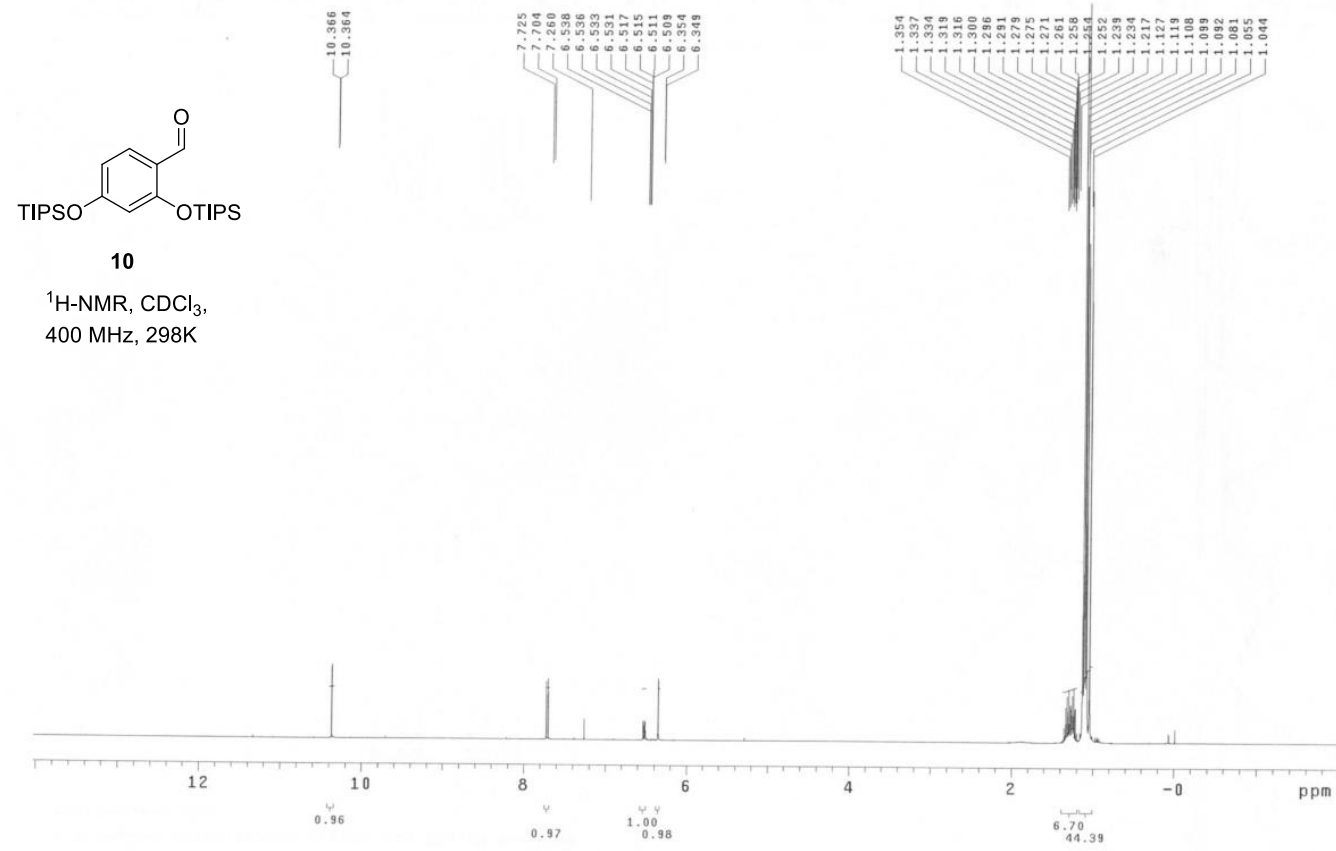

Pulse Sequence: s2pul

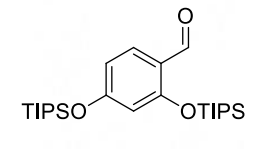

10

${ }^{13} \mathrm{C}-\mathrm{NMR}, \mathrm{CDCl}_{3}$,

$100 \mathrm{MHz}, 298 \mathrm{~K}$
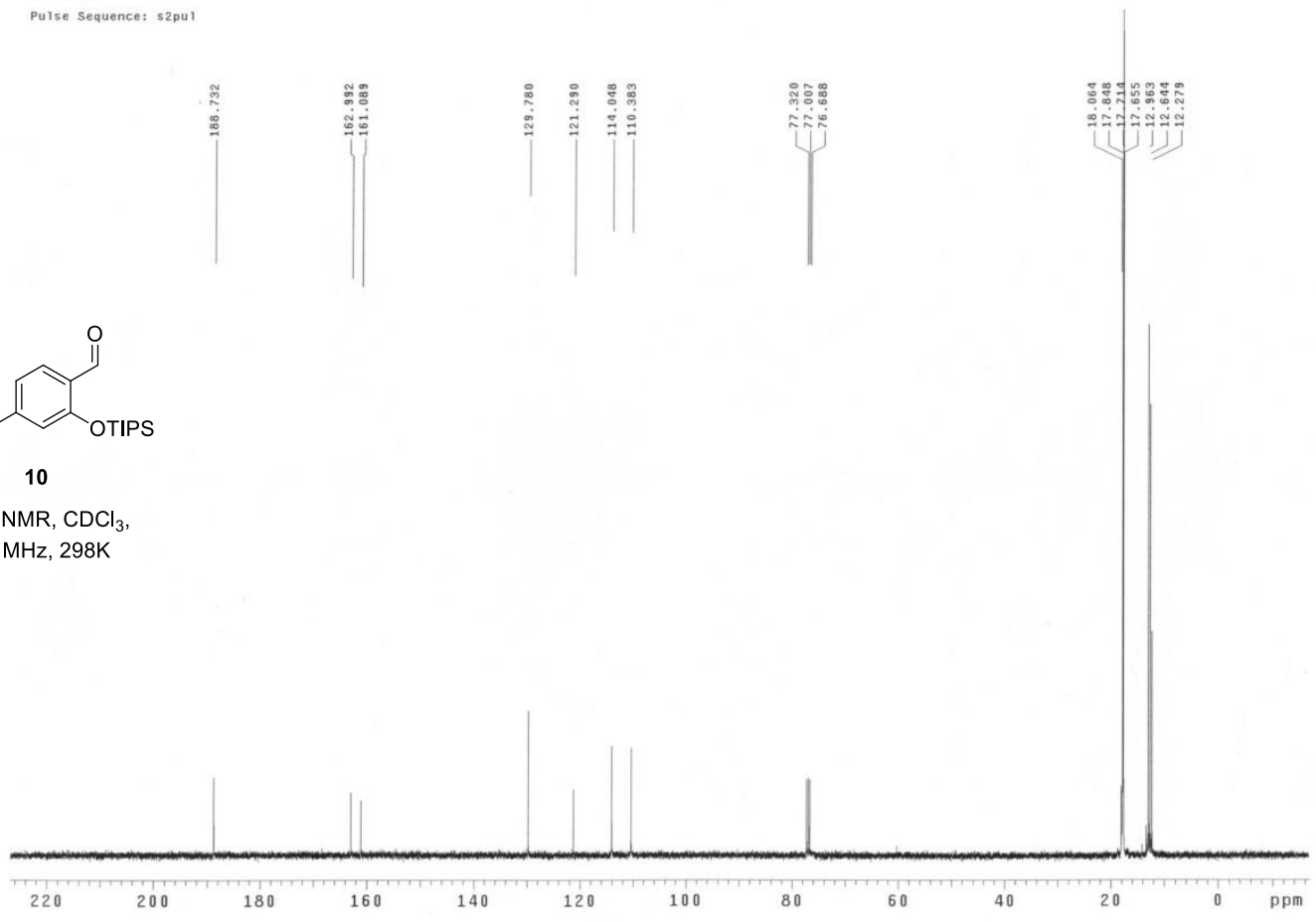
20150828-91-07-29-H-1

File: $\times p$

Pulse Sequence: 52pul
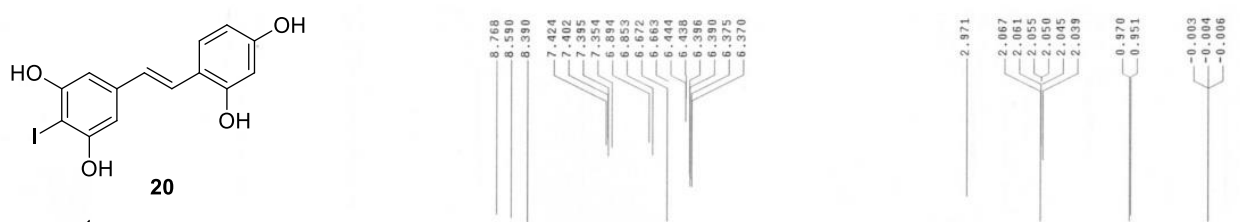

${ }^{1} \mathrm{H}-\mathrm{NMR}$, acetone- $d_{6}$

$400 \mathrm{MHz}, 298 \mathrm{~K}$
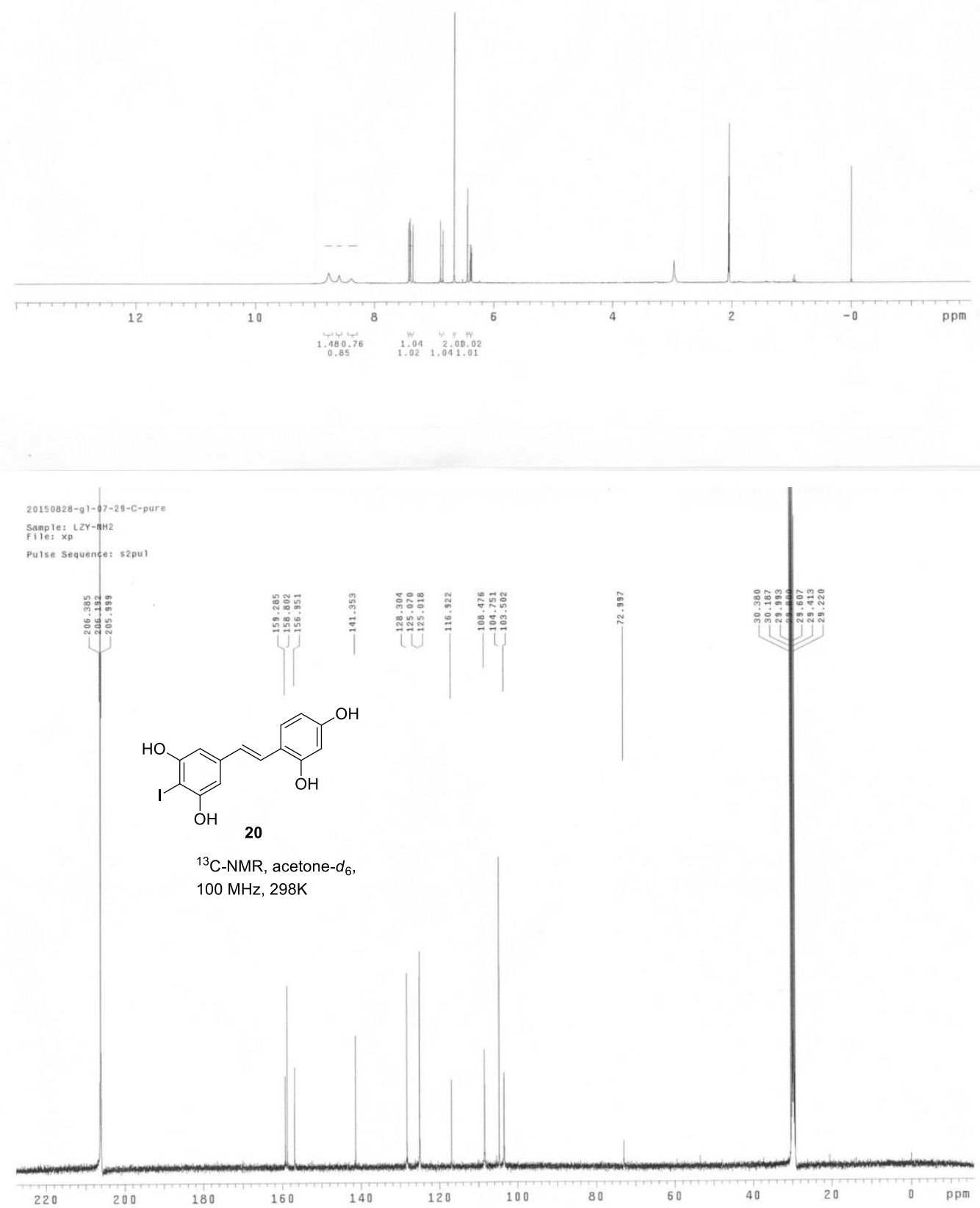


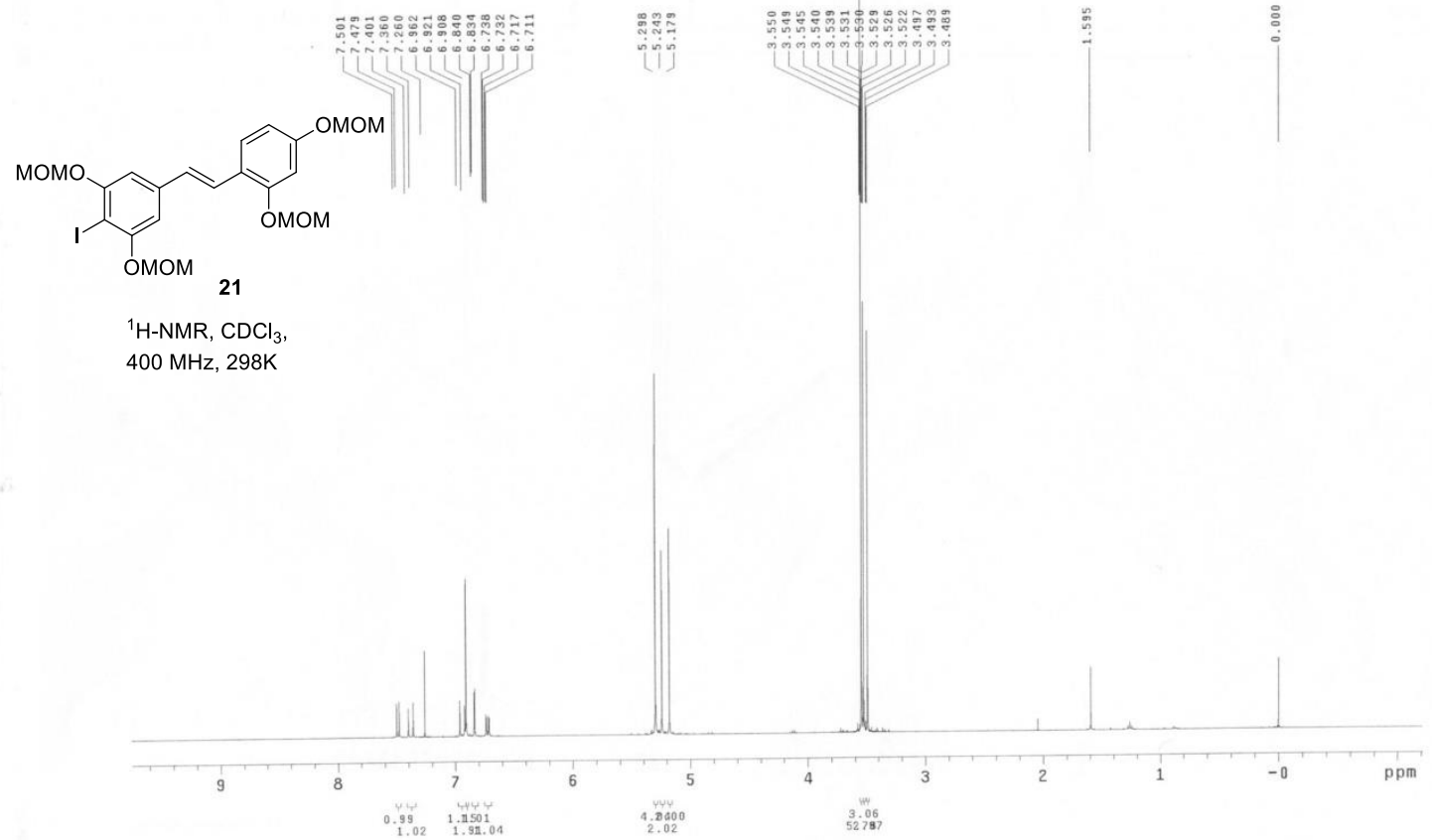

20150819-91-07-22-C-tn

File: home/lab/vnmrsys/data/gaolel/g1-07/20150819-g1-07-22-C-tm. fid

Pulse Sequence: s2put

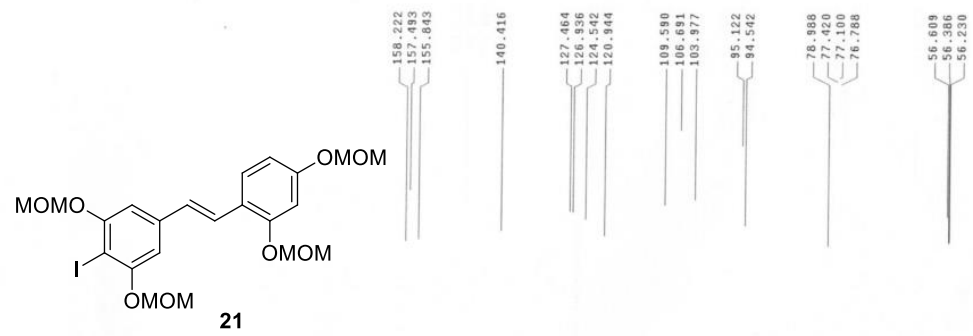

${ }^{13} \mathrm{C}-\mathrm{NMR}, \mathrm{CDCl}_{3}$

$100 \mathrm{MHz}, 298 \mathrm{~K}$

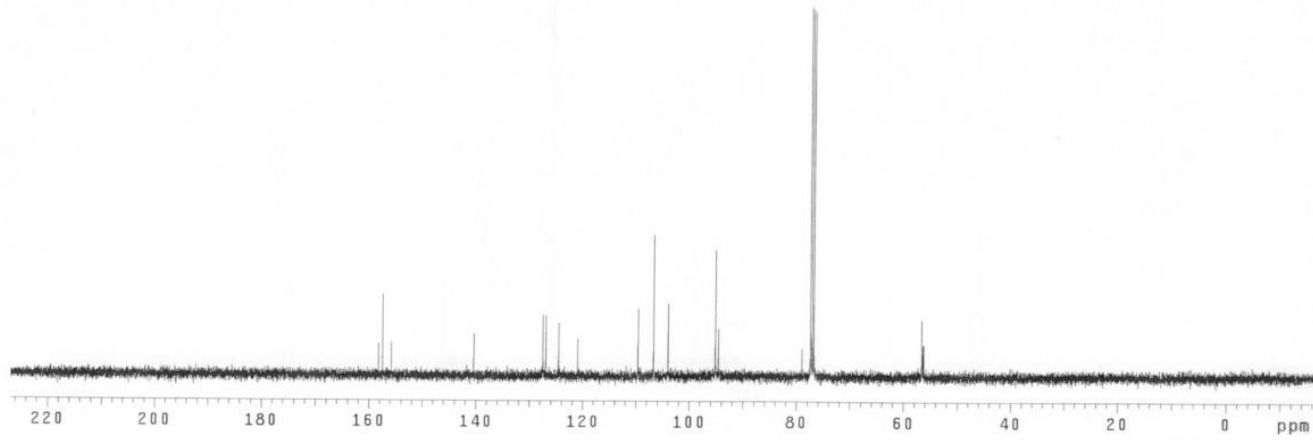


File: $\times p$

Purse Semence: s2pul
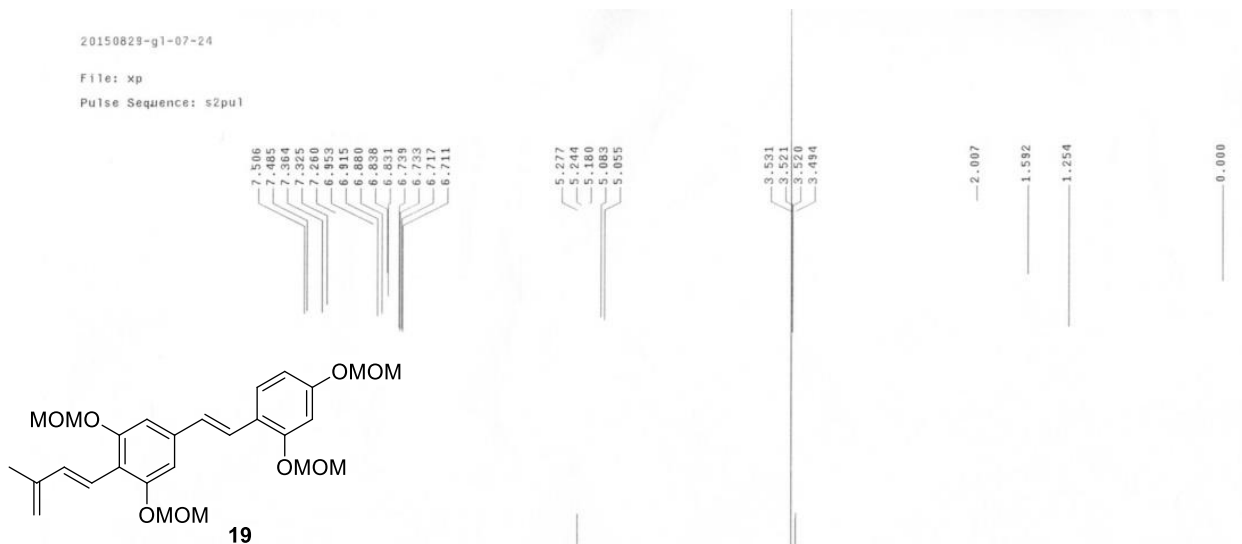

${ }^{1} \mathrm{H}-\mathrm{NMR}, \mathrm{CDCl}_{3}$,

$400 \mathrm{MHz}, 298 \mathrm{~K}$

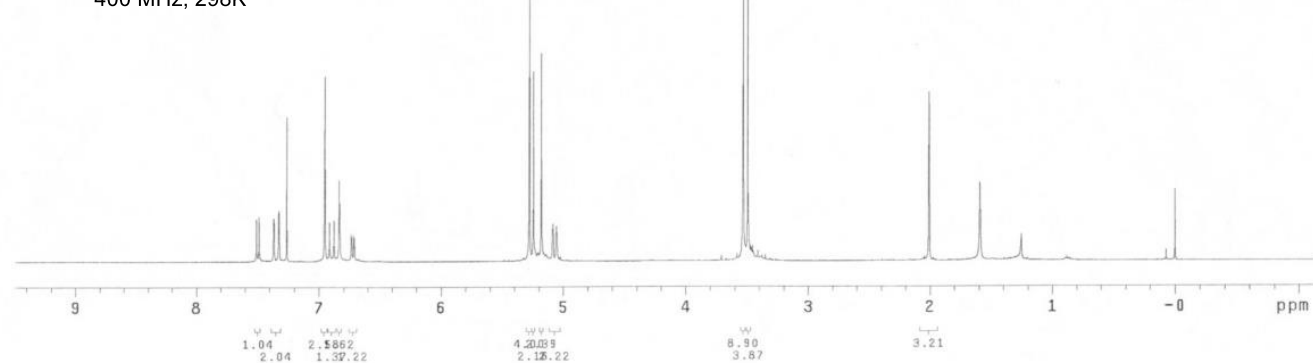

$20150829-91-07-24-C$

(11): $\mathrm{xp}$

ce: s2pu

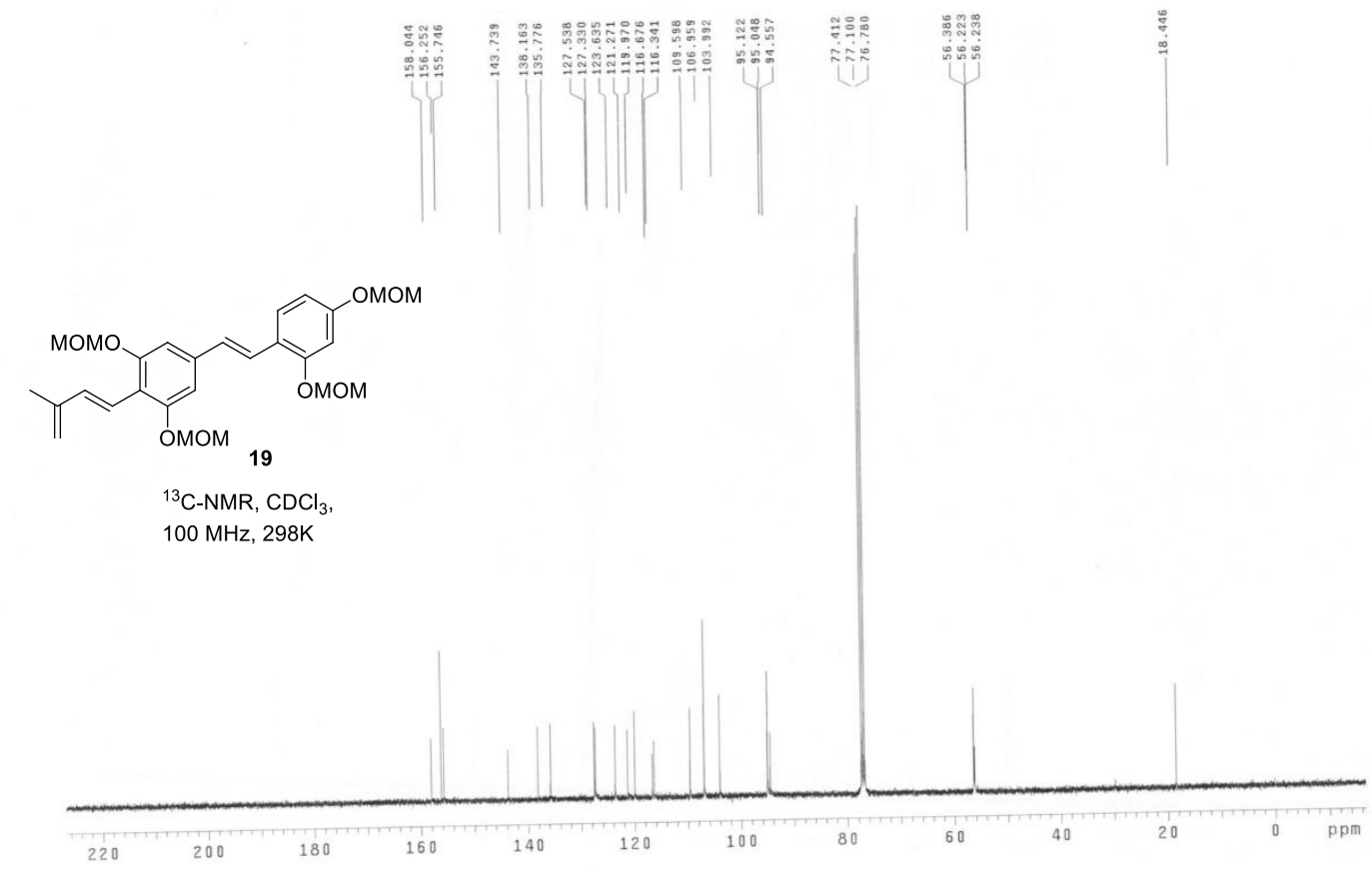


20150707-91-06-77-H-1

File: home/lab/vnarsys/data/gaole1/g1-06/20150707-g1-06-77-H-1.fld

Pulse Sequence: s2pul
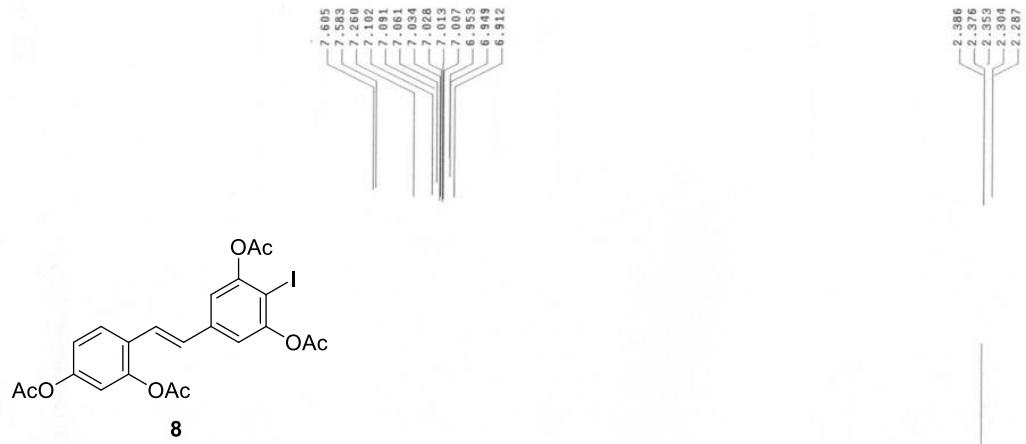

$\mathrm{H}-\mathrm{NMR}, \mathrm{CDCl}_{3}$

$400 \mathrm{MHz}, 298 \mathrm{~K}$

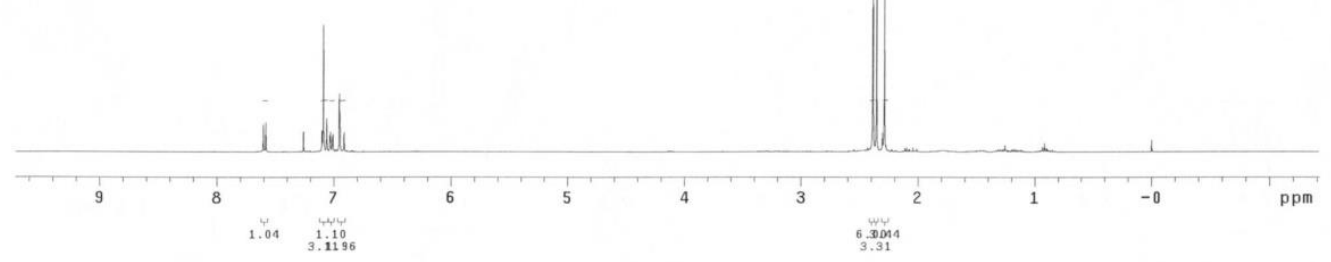

20150707-g1-06-77-C.

File: $\times$

Pulse Sequence: s2pul
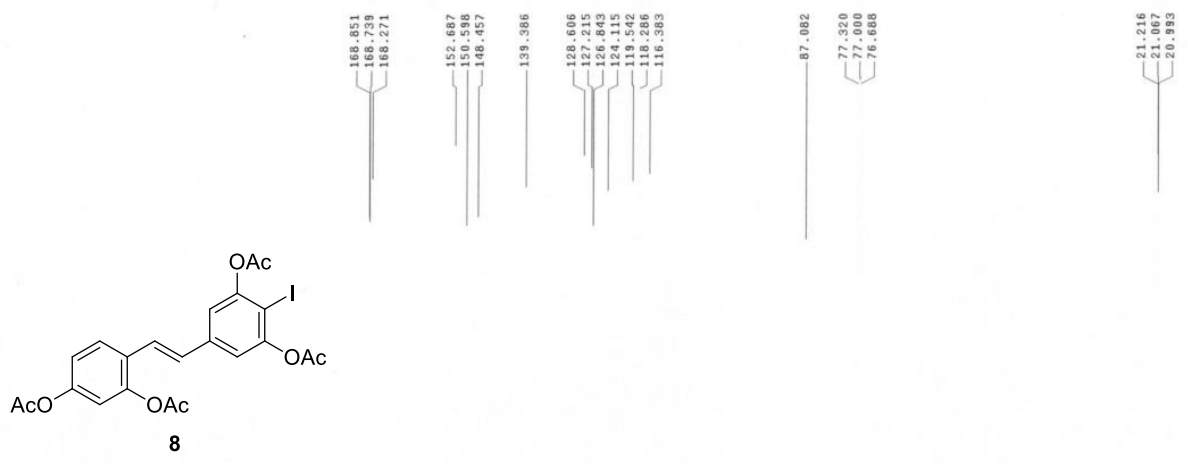

${ }^{13} \mathrm{C}-\mathrm{NMR}, \mathrm{CDCl}_{3}$,

$100 \mathrm{MHz}, 298 \mathrm{~K}$

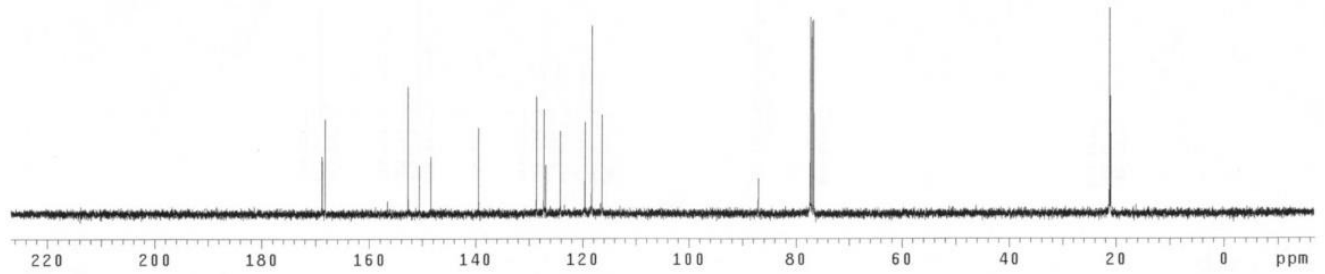


20150701-g1-06-36-2-H

F11e: $x p$

Sequence: 52 pul
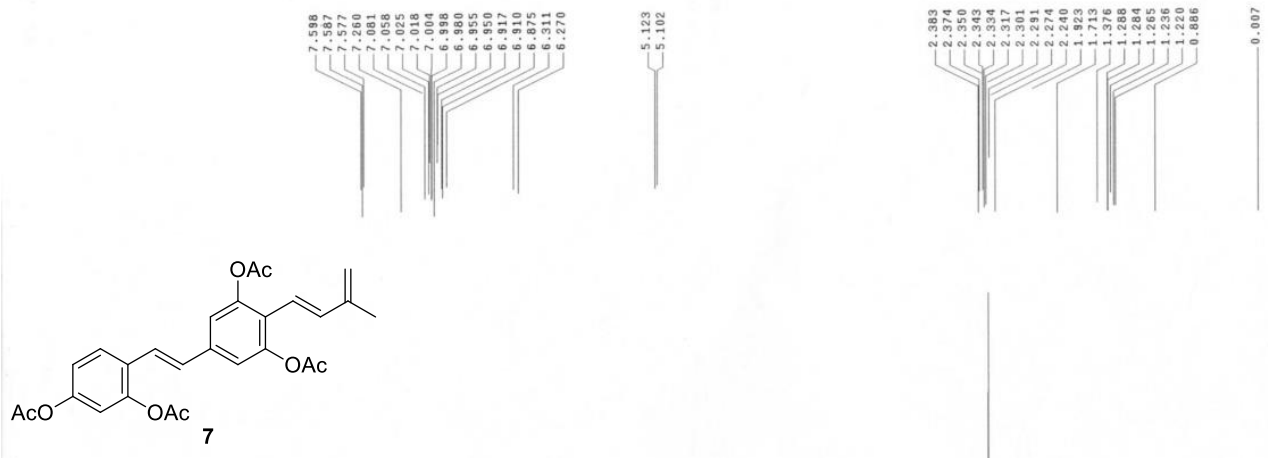

${ }^{1} \mathrm{H}-\mathrm{NMR}, \mathrm{CDCl}_{3}$,

$400 \mathrm{MHz}, 298 \mathrm{~K}$

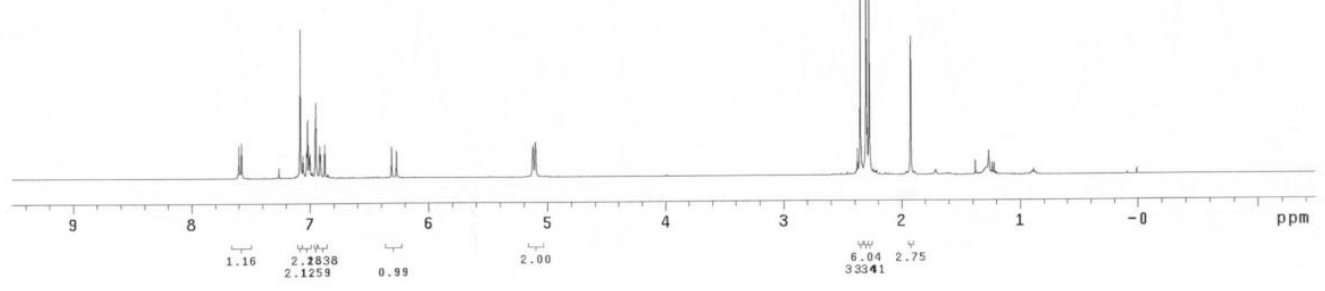

File: $\times p$

Pulse Sequence: s2pul

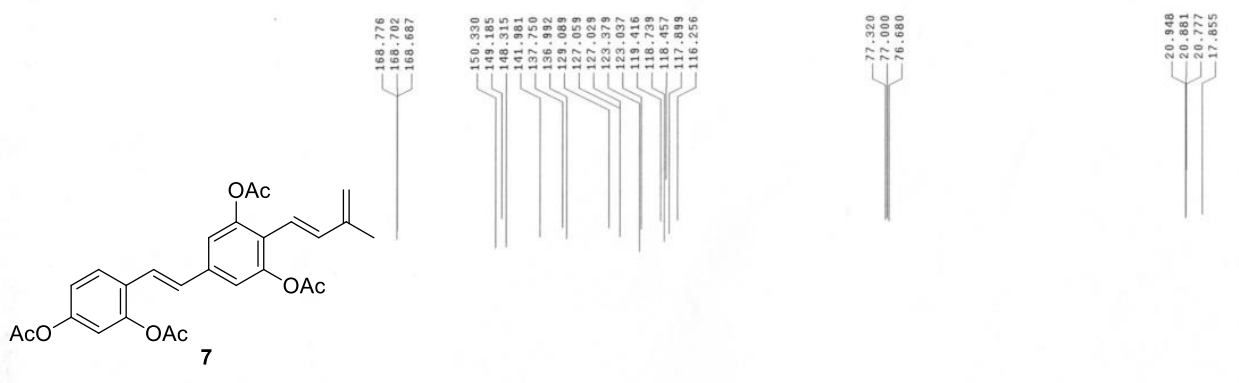

${ }^{13} \mathrm{C}-\mathrm{NMR}, \mathrm{CDCl}_{3}$

$100 \mathrm{MHz}, 298 \mathrm{~K}$

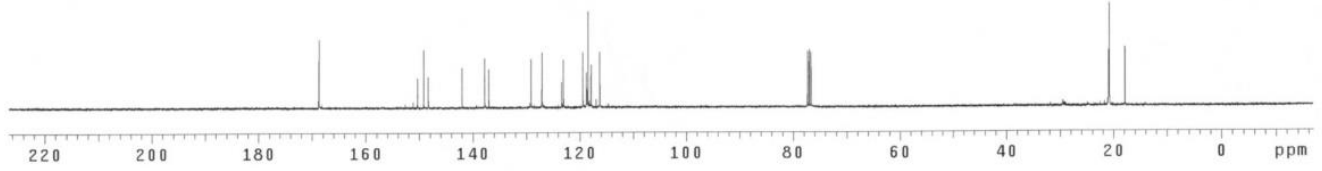




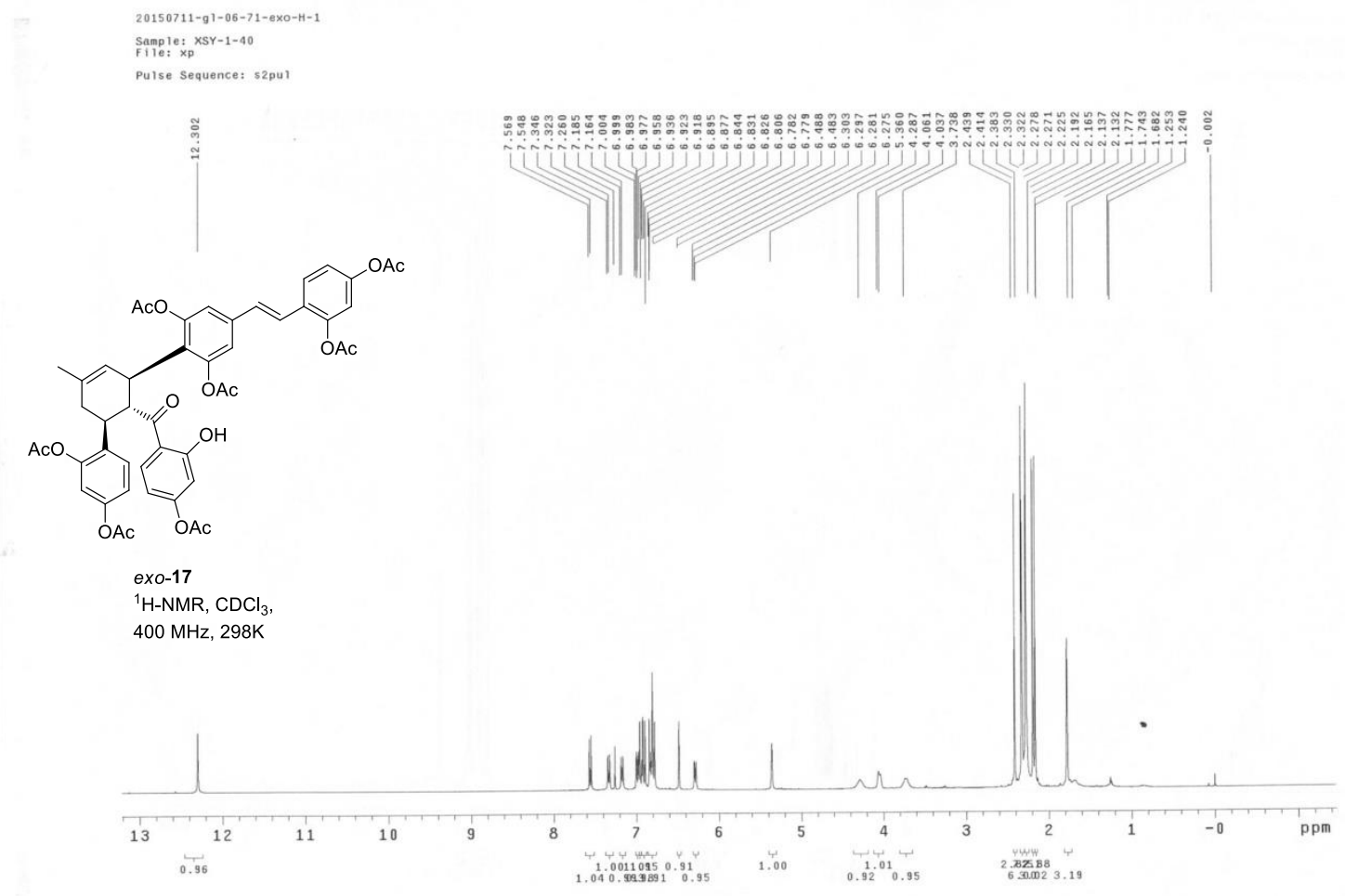

20150711-91-06-71-exo-H-C-1

File: $\mathrm{xp}$

Pulse Sequence: s2pu

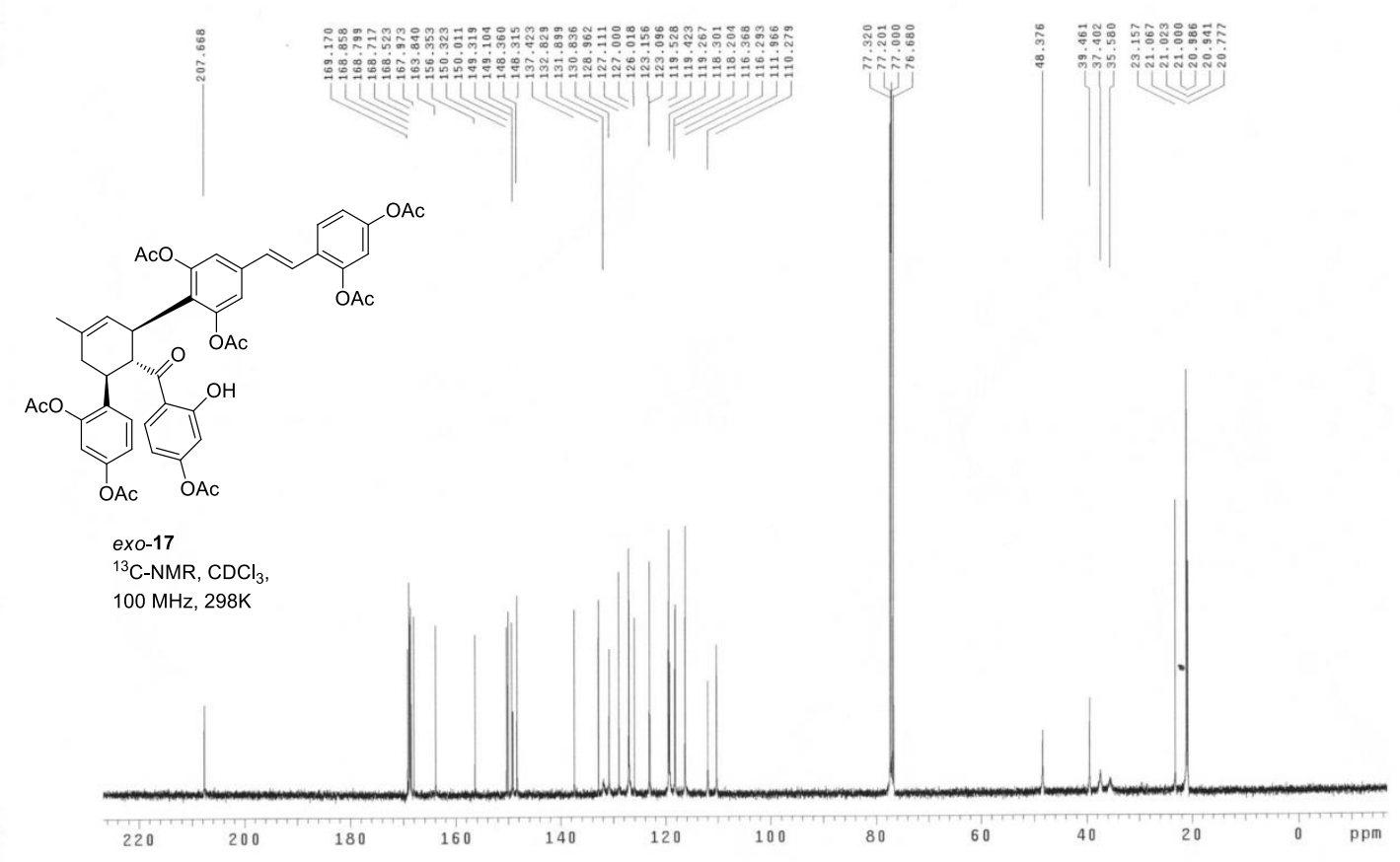




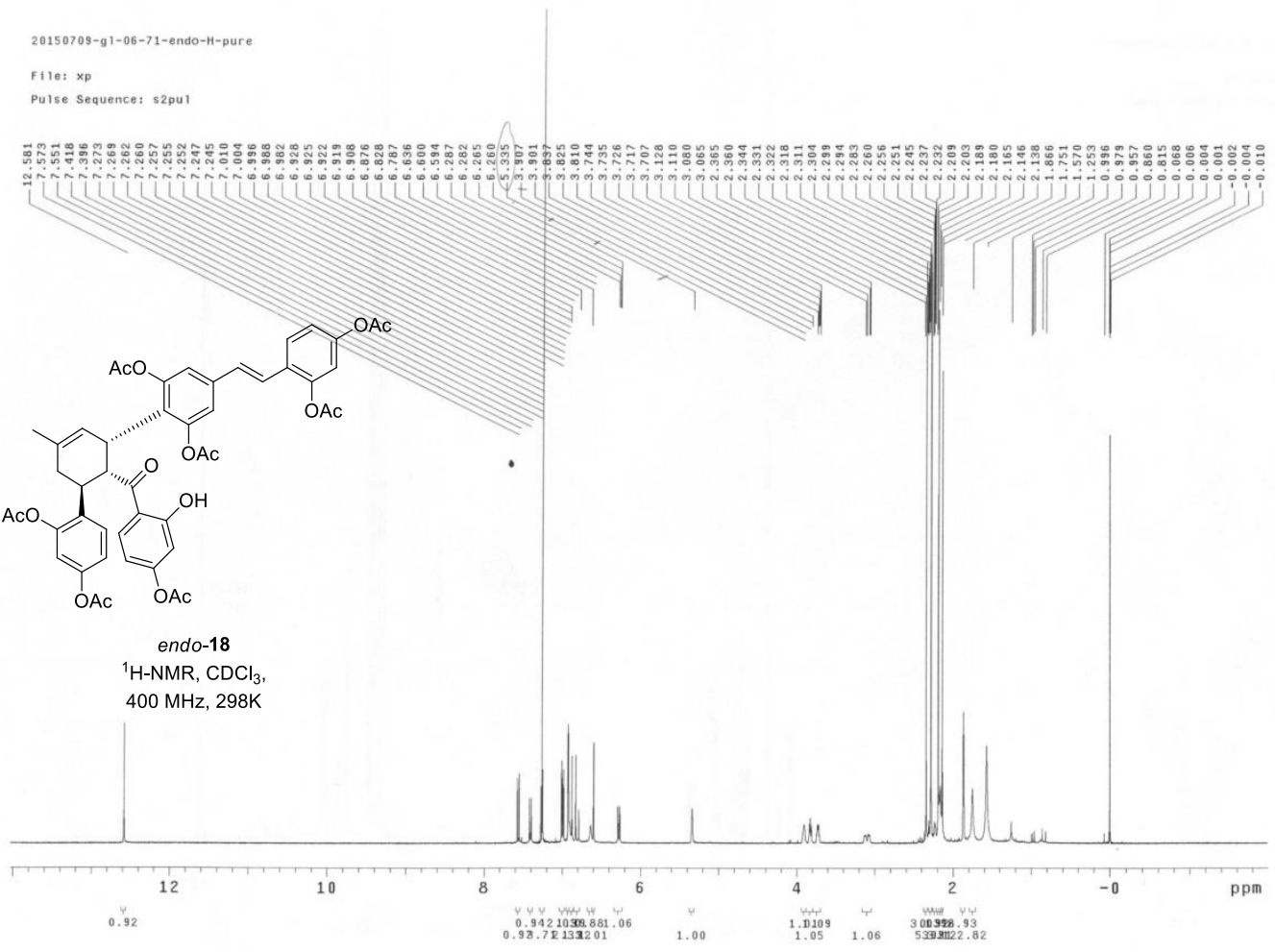

20150709-91-06-71-endo-c

11e: $x$
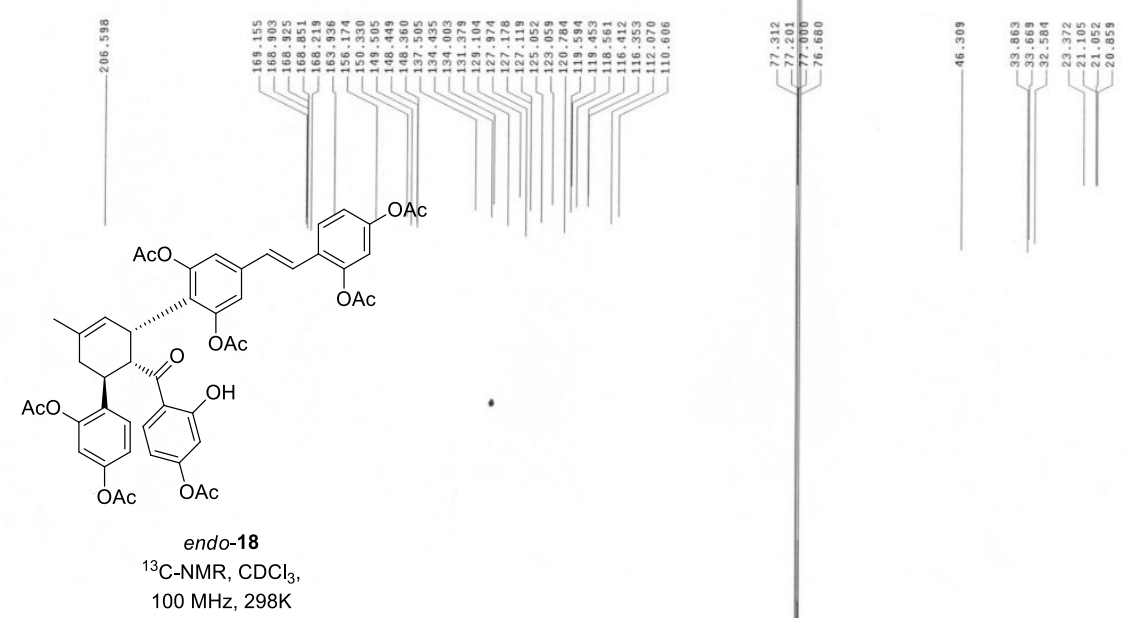
$20150826-91-07-28-e \times 0-4$

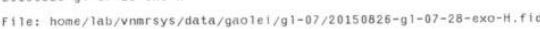

(19):

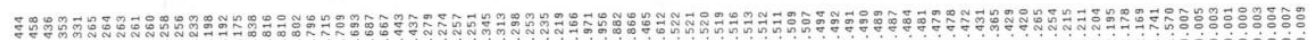

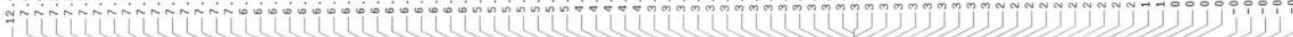

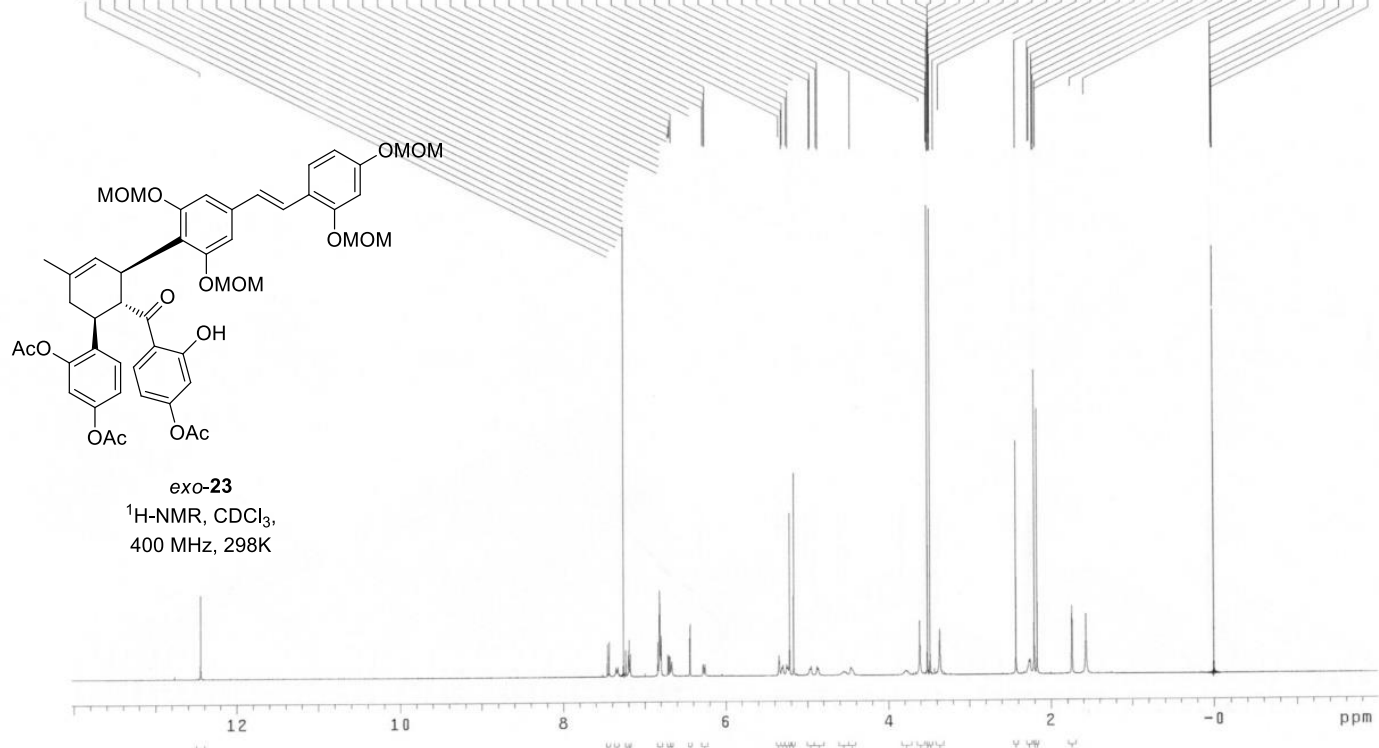

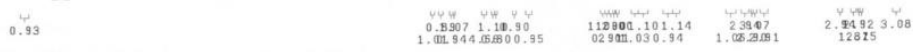

$20150826-91-07-28-e \times 0-\mathrm{C}$

pulse seguenes sapul

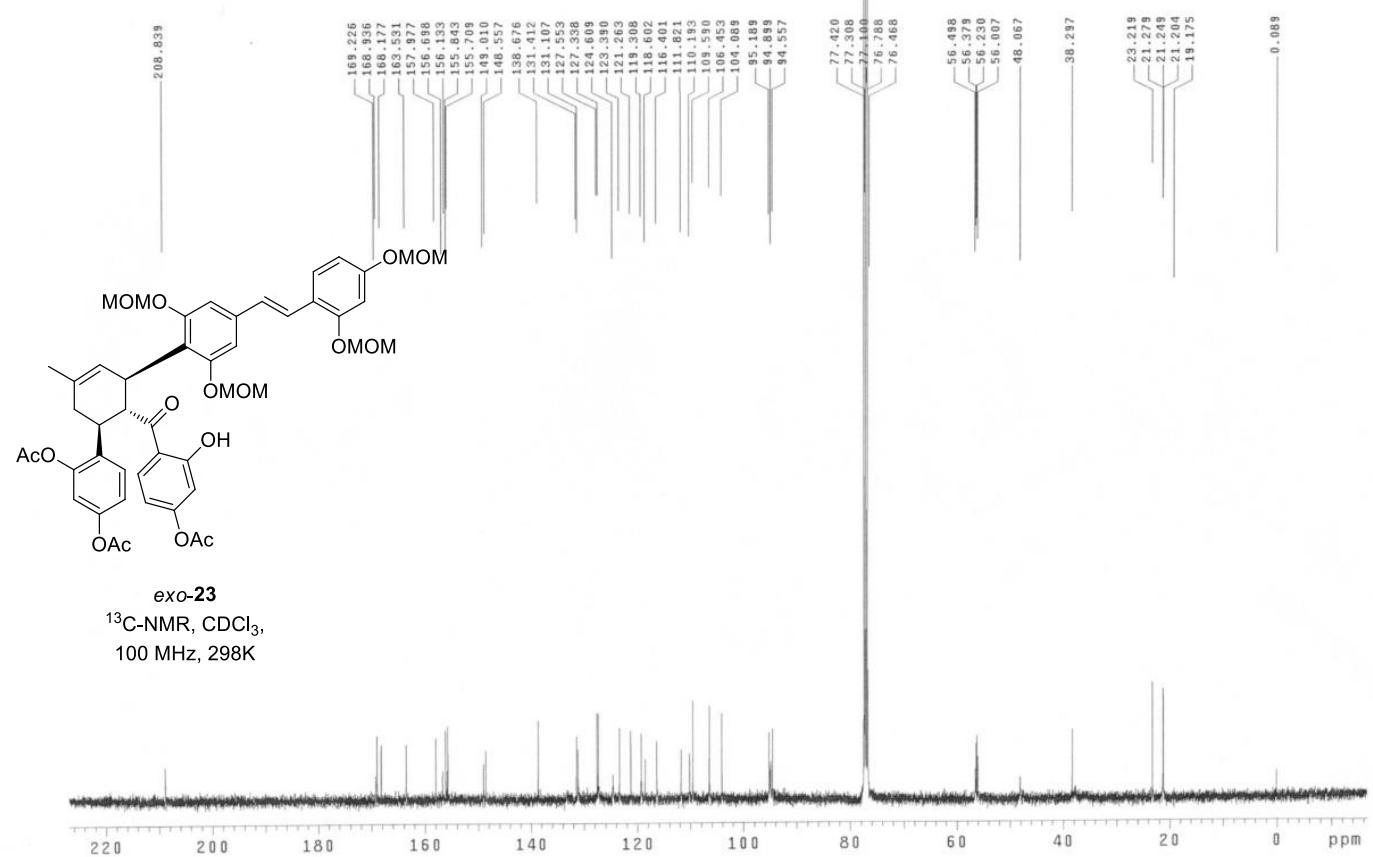




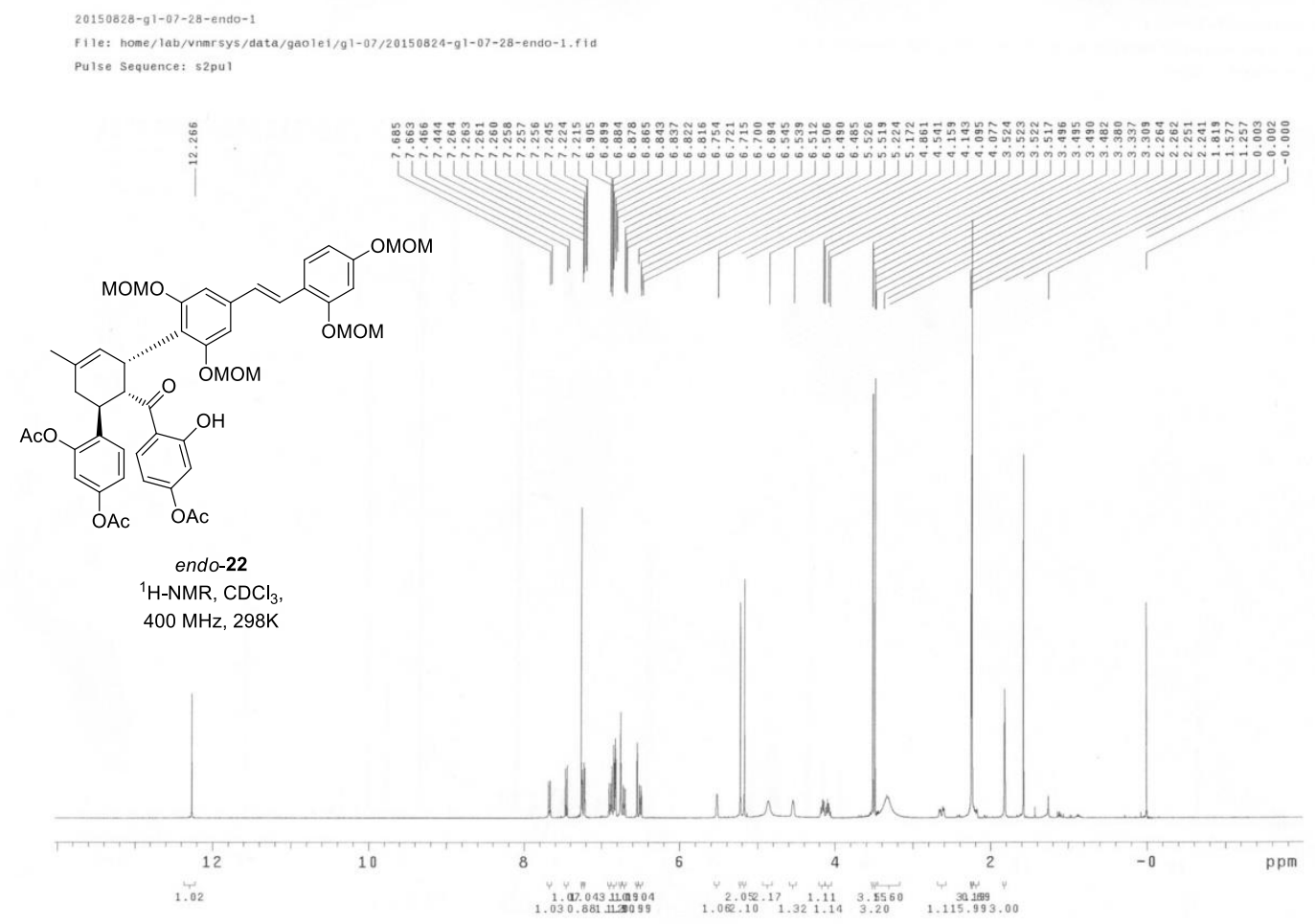

20150825-91-07-28-endo-C-4

File: home/lab/vnarsys/data/gaole1/20150825-g1-07-28-endo-C-4.fid

Pulse Sequence: s2pul
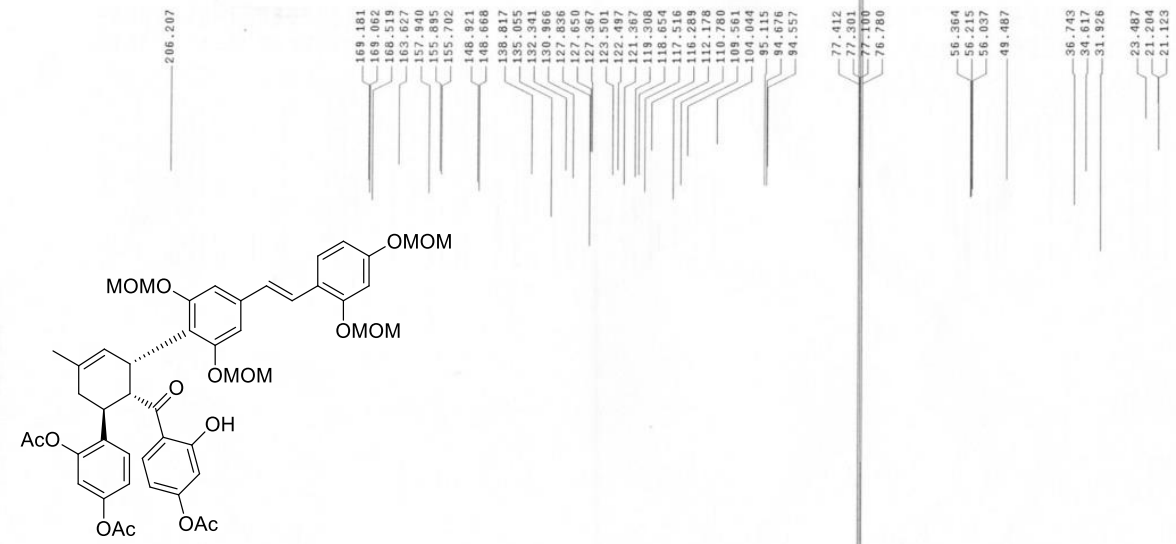

endo-22

${ }^{13} \mathrm{C}-\mathrm{NMR}, \mathrm{CDCl}_{3}$

$100 \mathrm{MHz}, 298 \mathrm{~K}$

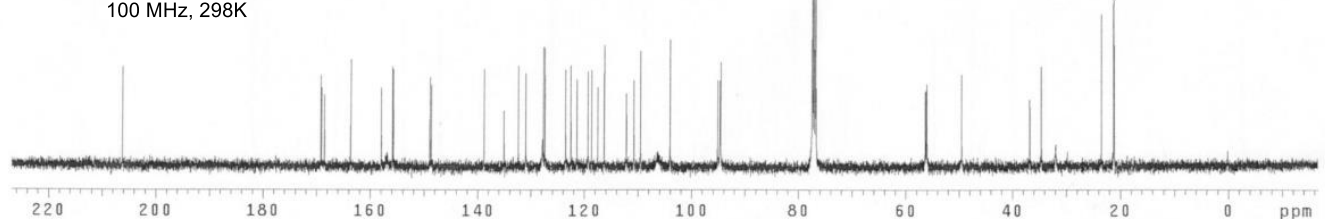




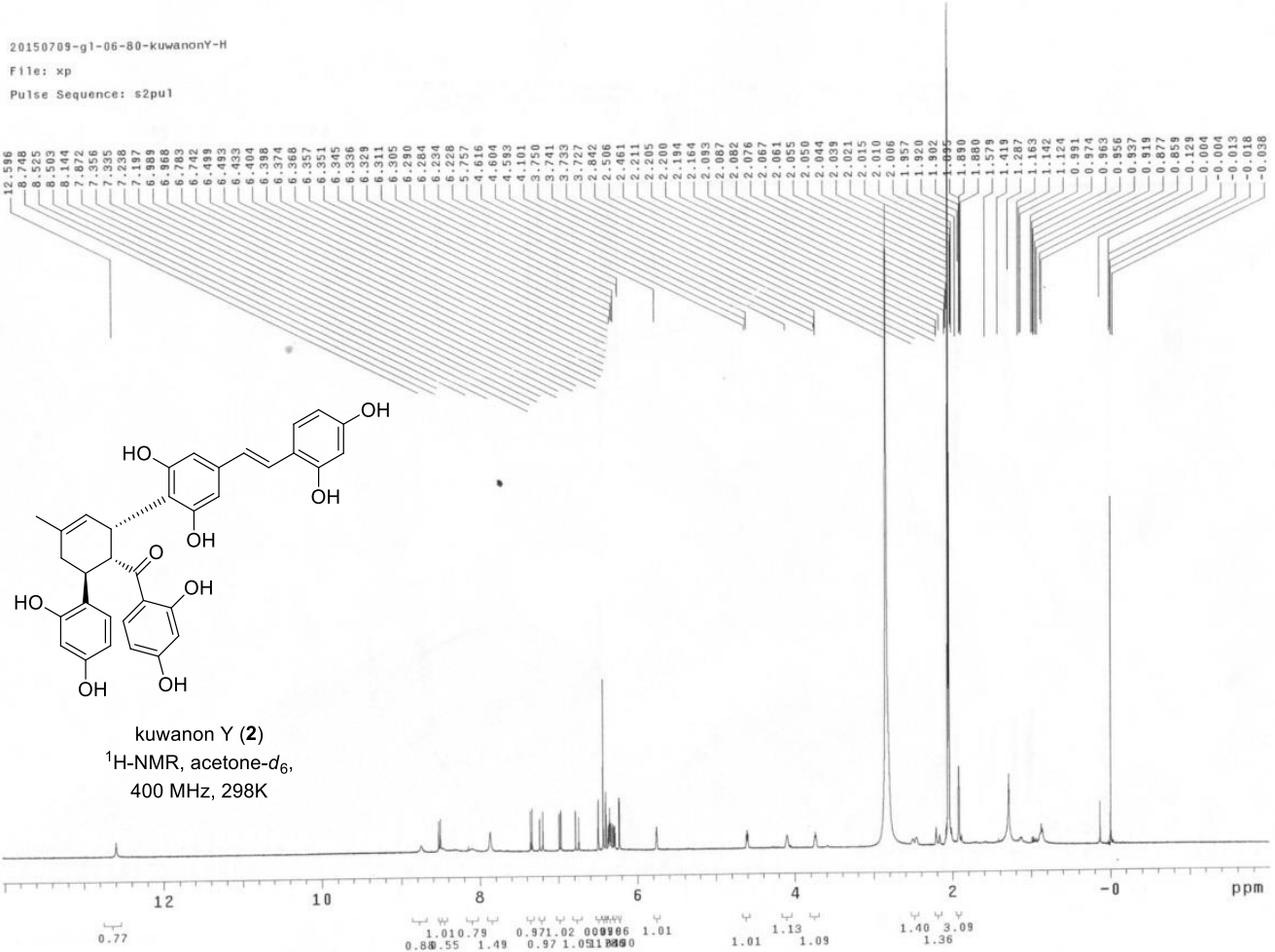

20150711-g1-06-78-kuwanony-

File: home/lab/vnimrsys/data/gaole1/g1-06/20150711-q1-kuwanolA.fid

Pulse Sequence: s2pul

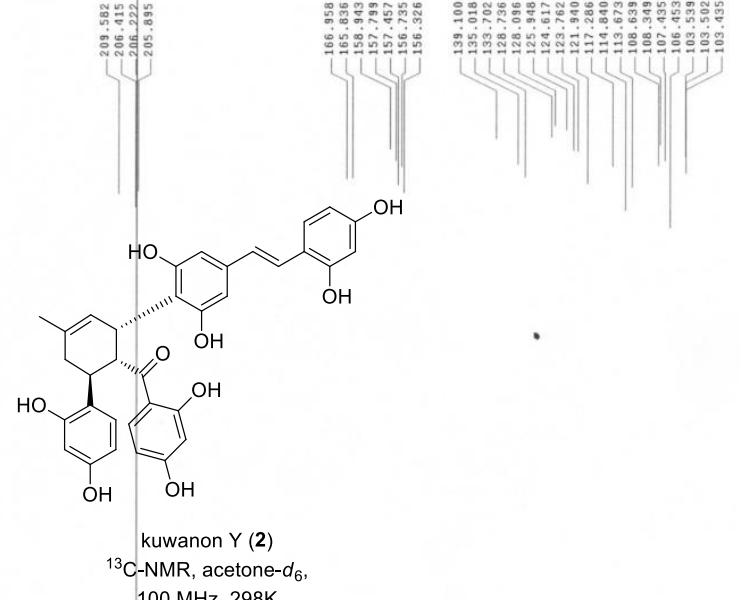

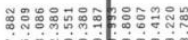

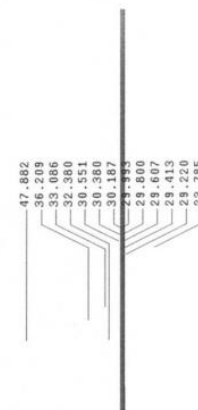

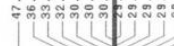
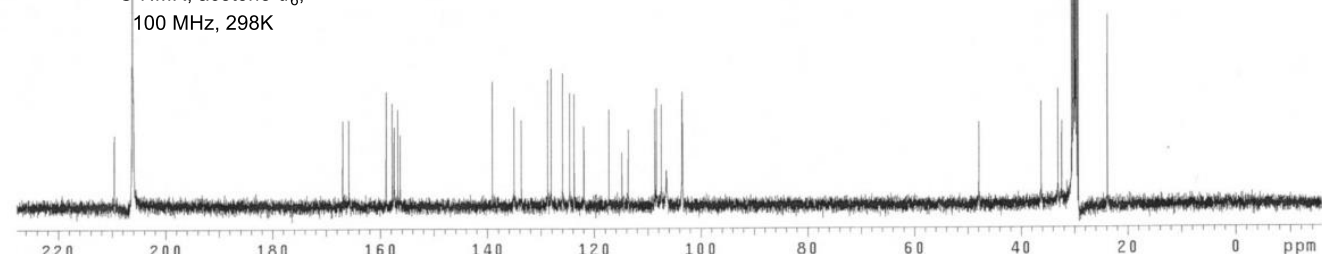


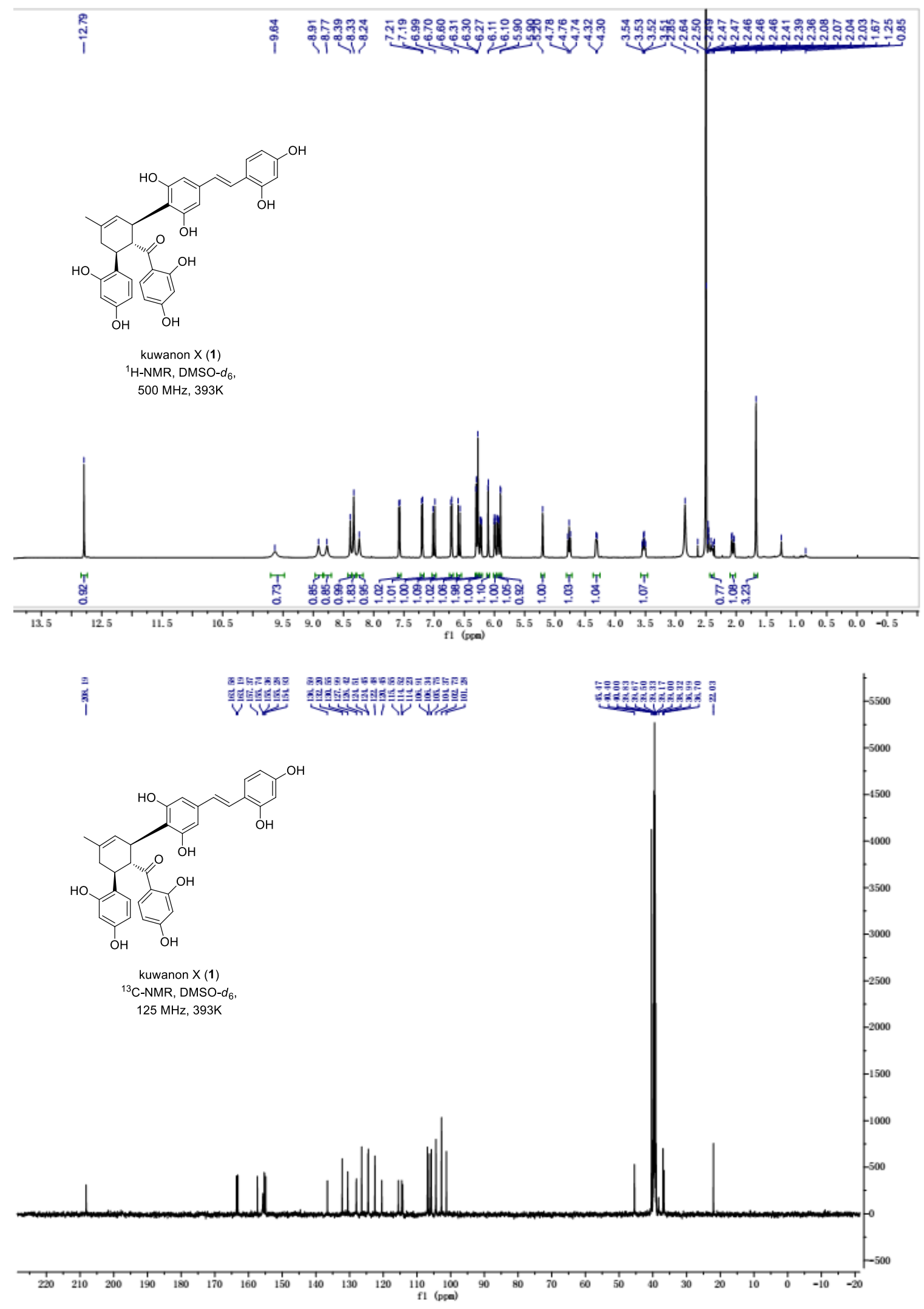



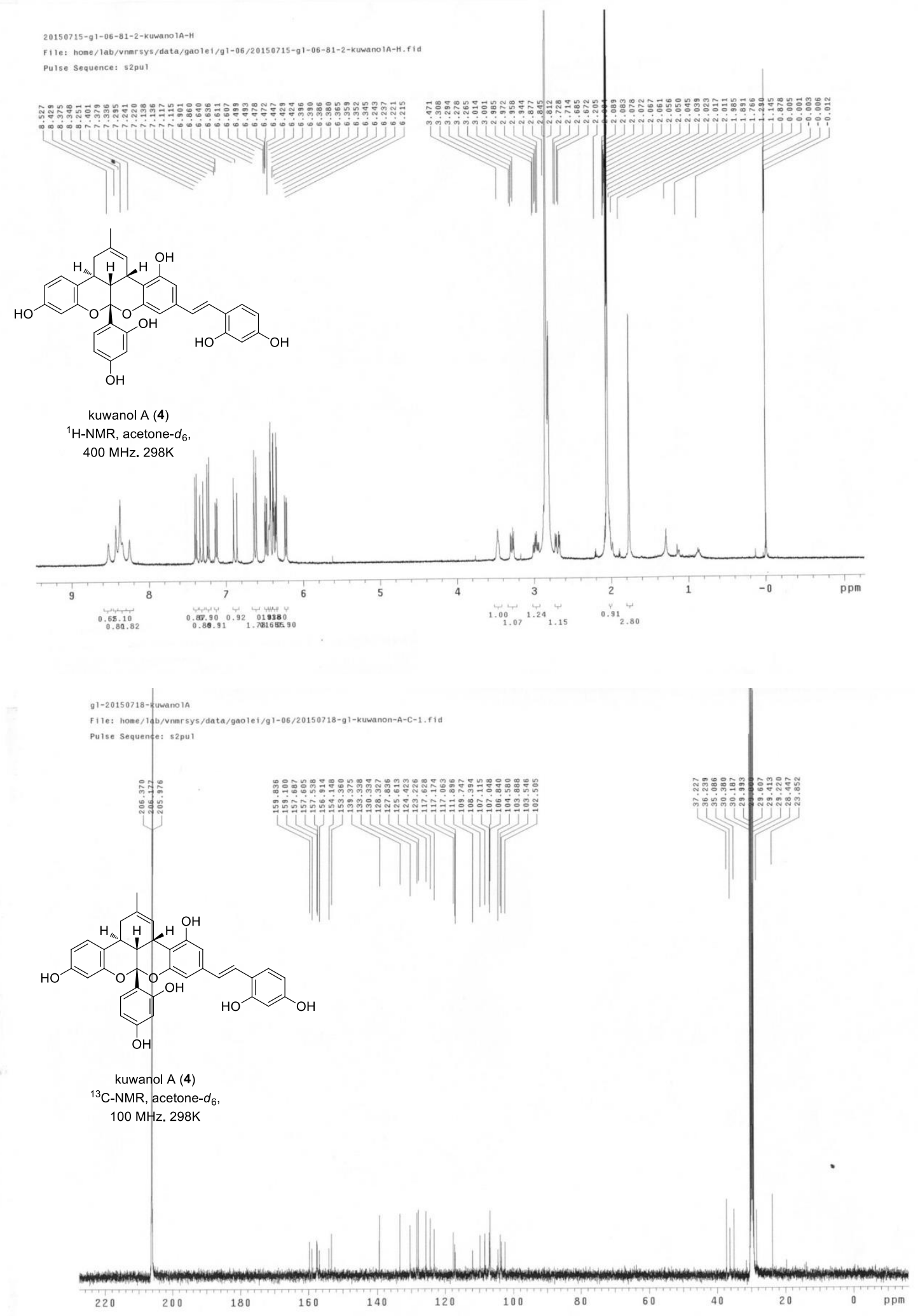